\title{
Ecological Studies in the Mammoth Cave System of Kentucky
}

\section{The Biota ${ }^{1}$ )}

\author{
By Thomas C. Barr, Jr. $\left.{ }^{2}\right)$
}

With plates 37 (1)-64 (28)

\section{Introduction}

The Mammoth Cave system, in Mammoth Cave National Park located in Edmonson, Barren, and Hart counties, Kentucky (Figs. 1, 2 ), is the longest known linear cave system in the world. The Park itself lies northwest of the Pennyroyal plateau on the western flank of the Cincinnati arch, just south of the axis of the Cumberland saddle (Weller, 1927). The Pennyroyal is a gently rolling, sinkhole-pitted, karst plain developed on the St. Louis and Ste. Genevieve limestones (Mississippian). The strata of the region dip northwestward at about 5.5 meters per kilometer.

The terrane of the Park south of Green River consists of irregular, wooded ridges separated by karstic valleys. The ridges represent remnants of a narrow, sandstone-capped upland which rises about 60 meters above the Pennyroyal, forming the distinctive Dripping Spring escarpment. The stratigraphic section in the ridges (Fig. 3) begins basally with Ste. Genevieve limestone, overlain consecutively by the Girkin limestone, the Big Clifty sandstone, and (locally) the Golconda and younger formations. It is within the Ste. Genevieve and Girkin limestones that the Mammoth Cave system has been excavated.

Green River flows through the Park in a westerly direction, occupying a meandering, youthful valley about 110 meters deep and passing just north of the Historic Entrance to Mammoth Cave. Large streams

1) This investigation was supported by a grant from the National Science Foundation (G-18765).

2) Institute of Speleology, Thomas Hunt Morgan School of Biological Sciences, University of Kentucky, Lexington, Kentucky, U.S.A. 40506. 
in the lowest level of the caverns debouch into Green River via springs, the most prominent of which are Echo and Styx River outlets (Mammoth Cave Ridge), Pike Spring (Flint Ridge), and Turnhole Spring (Joppa Ridge). The ridges in the portion of the Park south of the river contain most of the caves. Mammoth Cave lies within Mammoth Cave Ridge and its spur, Jim Lee Ridge. Flint Ridge, to the east, is honeycombed by a largely integrated network of passages slightly exceeding Mammoth Cave in total length of mapped passages, its various connected segments being known as Floyd Collins Crystal Cave, Great Salts Cave, Colossal Cave, and "Unknown Cave." Great Onyx Cave, also in Flint Ridge and genetically part of the same system, has not been directly linked with these other caves. Joppa Ridge, west of Mammoth Cave Ridge, is noted for Proctor Cave, Long (= Grand Avenue) Cave, and the Cedar-Sink-Turnhole system. Because of the regional dip, most of the larger caves are in the southeast half of this ridge. Adequate mapping of the caves of the Park is still far from complete, but fairly accurate surveys of nearly 175 kilometers of the system have been made. Recent explorative attempts to connect Mammoth Cave and the Flint Ridge system have not been successful.

Since Mammoth Cave itself has received more attention from zoologists than other caves of the area, a brief description is necessary for reference. Approximately 75 kilometers of passages are shown on the National Park Service surveys and on the 1908 map prepared by Max Kaemper and Edward Bishop (on file at Headquarters, Mammoth Cave National Park), but no single, comprehensive map of the entire, known parts of the cave is now available. A single natural entrance (Historic Entrance) is known; New Entrance, Frozen Niagara Entrance, Carmichael Entrance, Violet City Entrance, New Discovery Entrance, and an 81-meter elevator shaft to Marion Avenue near Snowball Dining Room are the present usable artificial entrances. The old Cox and Cathedral Domes entrances are hazardous and have been closed by rockfall. Most of the faunal collections of early investigators were made in the so-called "Historic Section" of the cave (Fig. 4 A) particularly near Richardson Spring, in the Labyrinth, along the Rivers, and in Washington Hall. In addition to these areas, I have found the following places especially productive: Fairy Grotto, Cathedral Domes, Crevice Pit and Mammoth Dome, Roaring River, Gratz Avenue, Marion Avenue, New Entrance, New Discovery in the vicinity of the artificial entrance, and the Frozen Niagara section (especially Moonlight Dome, Crystal Lake, and the RadioRoom). A sketch of the tourist portions of the cave and some detail of the Historic Section are shown in Figure 4. 
Five or six "levels" occur in the Mammoth Cave system, both in Mammoth Cave Ridge and Flint Ridge. Mammoth Cave is entered on the First (uppermost) Level through the Historic Entrance (Fig. 5), just below the cap rock of Big Clifty sandstone. Beyond the Rotunda, the Main Cave ("Broadway") drops into the Second Level, while the First Level continues as Gothic Avenue. The Third and Fourth levels are represented by passages of somewhat smaller cross-sectional dimensions, and the Rivers are found in the deepest, or Fifth Level of the cave. Much of the cave is dry, occasionally even dusty, and devoid of stalactitic deposits and fauna (Fig. 6). The upper levels are of zoological interest chiefly where the sandstone cap has been breached, and surface water finds its way into the cave: (1) in the vicinity of domepits, which are natural vertical shafts cut by sinking streams subsequent to the development of the horizontal passages; and (2) in the vicinity of terminal breakdowns, where the passage roof has collapsed because of surface erosion above the cave.

Two other small caves in Mammoth Cave Ridge merit mention. White Cave (Fig. 7), 0.8 kilometer west of the Mammoth Cave Hotel, is a broad, damp stalactitic passage segment about 150 meters long, apparently in communication with Crevice Pit of Mammoth Cave via a narrow fissure impenetrable by man. The terrestrial and temporary pool fauna is especially rich and varied. Dixon Cave, east of Historic Entrance, is a high, rocky-floored gallery 240 meters long and up to 20 meters high (Fig. 8), presumably the truncated lower end of the avenue by which Mammoth Cave is presently entered. It is of primary zoological interest because of its habitation by bats, but a few terrestrial arthropods occur at the end.

Numerous caves are developed along the Pennyroyal plateau and the base of the Dripping Spring escarpment northward to the Ohio River and southwestward to the Tennessee border. Marked changes in the composition of the cave faunas occur as one travels eastward from Mammoth Cave into the Warsaw-Fort Payne karst plateau developed on the slope of the Cumberland saddle, and lesser, but readily noticeable changes occur traveling in either direction along the Pennyroyal plateau. The sharpest faunal break is approximately indicated by the zone of contact between the St. Louis and Warsaw limestones to the east. A minor break is indicated by the pre-Pennsylvanian river channel (Burroughs, 1923) which extends eastward across northern Hart County, just north of Munfordville. Faunal changes to the southwest, along the Pennyroyal plateau, are more gradual. These changes are discussed in more detail below. 
The present study was begun in August, 1961, although I have made occasional field trips and observations on the Mammoth Cave fauna since 1955. The investigations of 1961-1963, carried out jointly with Robert A. Kuehne, will be reported in Part II of this paper. In Part I, the composition and development of the Mammoth Cave community are discussed, concluding with a discussion of the zoogeographic aspects of the troglobitic fauna.

\section{Acknowledgments}

I wish to express my appreciation to Superintendent Perry Brown and his successor, Paul McG. Miller, Mammoth Cave National Park, and to their staff, especially naturalists Richard Burns, Willard E. Dilley, George Olin, W. R. Steenburgh, Ray Nelson, and John Krisko, for cooperation in making this investigation possible. I am especially grateful to the many individuals who have accompanied and assisted me in the caves-my students, both graduate and undergraduate; members of the National Speleological Society and Cave Research Foundation; National Park Service personnel; and colleagues, especially Leslie R. Hubricht and R. A. Kuehne. The following systematists have, some of them over the course of nearly 12 years, determined the material collected: Gastropoda - Leslie Hubricht; Cladocera and Copepoda - Harry C. Yeatman; Isopoda - Leslie Hubricht, H. R. Steeves, III, A. Vandel, and W. B. Muchmore; Amphipoda - Leslie Hubricht and J. R. Holsinger; Decapoda - H. H. Hobbs, Jr.; Chelonethida W. B. Muchmore; Opiliones - C. J. Goodnight; Araneae - W. J. Gertsch; Acarina - R. W. Strandtmann, J. R. Holsinger, J. A. Wallwork, and G. M. Kohls; Diplopoda- N. B. Causey; Chilopoda- R. A. Crabill, Jr.; Collembola - K. A. Christiansen; Thysanura - P. Wygodzinsky; Orthoptera - T. H. Hubbell; Hemiptera - R. I. Sailer; Corrodentia - E. L. Mockford; Diptera - P. H. Arnaud, R. J. Gagné, G. D. Gill, and C. W. Sabrosky; Coleoptera Pselaphidae - Orlando Park; Coleoptera Staphylinidae - M. W. Sanderson; Teleostei - R. A. Kuehne; Chiroptera - W. H. Davis. Further assistance in preparation of this paper was provided by Mr. Hubricht and by Drs. Gertsch, Hubbell, Kuehne, Yeatman, and W. L. Jellison.

\section{Review of Literature}

The first written record of Mammoth Cave is the original Land Certificate (No. 2428, Survey Packet No. 2599) to Valentine Simons, 
dated September 14, 1798, and preserved in the Kentucky State Capitol at Frankfort. This document mentions "two [salt] Peter caves" (Mammoth and Dixon). After changing hands several times during the year 1812, at which time it became known as "the Mammoth Cave", the cave was operated as a saltpeter mine by Charles Wilkins and Hyman Gratz. A decline in demand for saltpeter followed the War of 1812 , and the cave was exploited for tourist purposes. The first major discoveries were made during the brief ownership of Frank Gorin, whose Negro slave, Stephen Bishop, crossed the Bottomless Pit on a rude "cedar" ladder in 1837, found Styx and Echo rivers, and explored more than 15 kilometers of galleries in the cave before his death in 1855. Dr. John Croghan acquired the cave in 1839, and it remained in the hands of the Croghan heirs until purchased by the Mammoth Cave National Park Association in 1929. An excellent description of Mammoth Cave and its surroundings at the time of the Croghan purchase was written by Robert Davidson (1840), a Presbyterian minister from Lexington. Davidson's account contains the first published references to the blind fishes.

The first biologist to visit Mammoth Cave (1822-1826) was Constantin S. Rafinesque, naturalist and professor at Transylvania University in Lexington (Rafinesque, 1832). James DeKay's (1842) original description of a blind fish was followed by the investigations of Theodor Tellkampf (1844a, 1844b, 1845), the studies of Jefferies Wyman (1843, 1850, 1853) and Louis Agassiz $(1851,1853)$ on blind fishes, and the visit of the Russian coleopterist T. Victor von Motschulsky (1854, 1862). Further nineteenth-century faunal studies include those of Alpheus Spring Packard, Jr. (summary, 1888) and Richard Ellsworth Call (1897). Additional collections made by Bolívar and Jeannel (1931), Buchanan (1936), Hubricht (1943), and Henrot (Jeannel and Henrot, 1949) brought the knowledge of the Mammoth Cave fauna to the approximate position in which I found it at the beginning of the present study in 1955 .

A complete bibliography of Mammoth Cave would contain thousands of items. In the categorization which follows I have listed selected geological and geographical references and the primary biological references.

1. Geology, geography, and cave description. - Bretz (1942), Brucker (1966), Davis (1930), Gardner (1935), Jillson (1923), Lobeck (1929), Packard (1888), Pohl (1955), Pohl and White (1965), Shaler (1875), Swinnerton (1932), Watson (1966), Weller (1927).

2. General biology of the cave. - Bailey (1933), Barr (1955, 1964a, 1966), Bolivar and Jeannel (1931), Call (1897), Dearolf (1942), Eigen- 
mann (1899), Packard (1871,1888), Park (1939), Putnam (1872), Rafinesque (1832), Tellkampf (1844a, 1844b, 1845), and occasional references to the Mammoth Cave fauna in Poulson (1964) and Vandel (1964).

3. Protozoans. - Kofoid (1899), Packard (1888), Tellkampf (1845).

4. Flatworms. - Buchanan (1936), De Beauchamp (1931), Hyman (1937), Packard (1871, 1888).

5. Earthworms. - Gates (1959).

6. Snails. - Call (1897), Hubricht (1960, 1962, 1963, 1964, 1965).

7. Copepods. - Kofoid (1899), Chappuis (1931).

8. Ostracods. - Hart and Hart (1966), Hart and Hobbs (1961), Klie (1931), Kofoid (1899).

9. Isopods. - Hay (1903), Muchmore (1964), Packard (1871, 1885, 1888), Vandel (1965).

10. Amphipods. - Cope (1872), Hubricht (1943), Packard (1888).

11. Crayfishes and shrimps. - Bailey (1933), Brown (1961), Cope (1872), Fage (1931), Garman (1924), Hagen (1870, 1872), Hay (1903), Hobbs and Barr (1960), Packard (1871, 1888), Park, Roberts, and Harris (1941), Putnam (1875), Rhoades (1944), Smalley (1961), Tellkampf (1844a, 1844b), Wolfe and Cornwell (1964).

12. Pseudoscorpions. - Banks (1895), Hubbard (1880), Malcolm and Chamberlin (1961), Muchmore (1963, 1965), Packard (1888).

13. Harvestmen. - Bailey (1933), Call (1897), Goodnight and Goodnight (1960), Hubbard (1880), Packard (1871, 1888), Tellkampf (1844a, 1844b).

14. Spiders. - Bailey (1933), Berland (1931), Call (1897), Emerton (1875), Hubbard (1880), Keyserling (1881), Packard (1871, 1875 a, 1875b, 1888).

15. Mites. - Bailey (1933), Call (1897), Holsinger (1965), Packard (1888), Vitzthum (1925).

16. Millipedes. - Cope (1872), Hubbard (1880), Loomis (1943), Packard (1871, 1888).

17. Collembolans. - Call (1897), Christiansen (1960a, 1960 b, 1960 c, 1964, 1966), Packard (1888).

18. Diplurans. - Condé (1949), Packard (1871, 1874a, 1888), Silvestri (1934, 1947).

19. Thysanurans. - Hubbard (1880), Packard (1888), Tellkampf (1844a, 1844b).

20. Cave crickets. - Chopard (1931), Hubbell (1936), Packard (1888), Park and Barr (1961), Reichle, Palmer, and Park (1965).

21. Psocopterans. - Call (1897), Packard (1888).

22. Moths. - Bailey (1933), Packard (1888). 
23. Flies. - Bailey (1933), Call (1897), Hubbard (1880), Packard (1888).

24. Fleas. - Bailey (1933), Fox (1940).

25. Beetles. - Barr (1959a, 1959b, 1962, 1963, 1964b, 1967), Hatch (1933), Horn (1868, 1883), Hubbard (1880), Jeannel (1920, 1928, 1931, 1949), Motschulsky (1854, 1862), Packard (1871, 1874b, 1876, 1888), Park (1956, 1958, 1960), Tellkampf (1844a, 1844b), Valentine (1931, 1932).

26. Fishes. - Agassiz (1851, 1853), Bailey (1933), Barr and Kuehne (1962), DeKay (1842), Eigenmann (1905, 1909), Girard (1860), Kuehne (1966), Packard (1888), Poulson (1963), Putnam (1872), Rosen (1962), Tellkampf (1844b, 1845), Thompson (1844), Woods and Inger (1957), Wyman (1843, 1850, 1853).

27. Bats. - Bailey (1933), Hall (1961, 1962, 1963), Jegla and Hall (1962), Rafinesque (1832).

28. Algae. - Jones (1965), Nagy (1965), Van Landingham (1965, 1966).

29. Eumycophytes. - Brashear, Wiseman, and Barr (1967), Call (1897), Maheu (1926a, 1926b), Thaxter (1895).

30. Bryophytes. - Maheu (1926a).

\section{The Mammoth Cave Biota}

More species of animals and plants have been recorded from the Mammoth Cave system than from any other cave system in North America. This situation results from three main factors. (1) The Mammoth Cave flora and fauna have been collected by biologists more frequently and for a longer period of time than those of other caves. (2) As an extraordinarily large cave system, Mammoth Cave provides a great variety of microenvironments in which an unusually large number of organisms is able to exist. (3) The geological and geographical setting are especially favorable for dispersal of troglobites into the Mammoth Cave region, a feature which will be discussed in more detail later in this section. The great species diversity in the troglobite fauna of the system is thus not entirely an artifact resulting from more extensive collecting, but is in large proportion a natural consequence of regional geology, the heterogeneous assemblage of available subterranean microenvironments, and the rules of troglobite dispersal. 


\section{The Fauna}

Approximately 200 species of animals have been recorded from Mammoth Cave. [An exact number is meaningless because (a) some groups are taxonomically better known than others, (b) some groups are more readily collected than others, and (c) tourism and flooding favor the accidental introduction of non-cavernicolous species into Mammoth Cave.] Twenty-two per cent of the known species are troglobites; 36 per cent are troglophiles; 22 per cent are trogloxenes which regularly and commonly penetrate deeply into the caves (habitual trogloxenes), threshold trogloxenes, occasional trogloxenes, or parasites of other trogloxenes; and the remaining 20 per cent are accidentals. Troglobites are denoted below by an asterisk (*).

Protozoans. - Although inadequately investigated, protozoans are moderately abundant in the silts in bottoms of rivers, smaller streams, Crystal Lake, and temporary pools. They may also be anticipated in the hygropetric biota - the assemblage of organisms in the thin film of water covering cave walls and dripstone - although this microenvironment has not been properly evaluated within the Mammoth Cave system. The Shrimp Pools (inhabited by * Palaemonias ganteri) of the Roaring River passage contain species belonging to the genera Phacus, Paramecium, Halteria, Difflugia, and Peranema. Epistylis sp. is epizoic on tubificid worms in mud of the Roaring River passage. Most of the small rimstone pools with some source of food - rotting wood or guano of cave crickets - contain Difflugia, a few Halteria, and occasionally Phacus. Kofoid (1899) reports several protozoans from a plankton sample made in Echo River: 1 Amoeba limax Duj., 2 Difflugia globulosa Duj., 2 empty shells of Centropyxis aculeata var. ecornis Leidy, 3 clusters of the choanoflagellate Salpingoeca amphoridium J. Clark, and - epizoic on cyclopoid copepods - the flagellate Colacium vesiculatum Ehrenberg and the suctorian Podophrya cyclopum Clap.\& Lach. From what little is known of Mammoth Cave protozoans there is no indication of special modification or adaptation to the cave environment among these organisms, although this possibility has by no means been rigorously excluded. The protozoans mentioned by Tellkampf (1845) and Packard (1888) include forms attributed to Chilomonas (including C. emarginata Tellk.), Monas, Bodo, Colpoda, Nassula, and Chilodonella.

Porifera. - Kofoid (1899) reported a few spicules in a plankton sample from Echo River, which he attributed to Spongilla lacustris? Leidy, apparently accidental in the cave. 
Tricladida. - Mammoth Cave is the type locality for two troglobitic planarians, both belonging to the North American family Kenkiidae * Sphalloplana percaeca (Packard) and * Speophila buchanani Hyman (see de Beauchamp, 1931, and Hyman, 1937, for descriptions and Buchanan, 1936, for behavior). These flatworms typically occur in (a) rather large but temporary drip pools (e.g., intermittent rimstone pools in White Cave or Lake Purity in Gratz Avenue of Mammoth Cave); or (b) on the undersides of rocks in shallow, flowing streams (e.g., Shaler's Brook in Gratz Avenue, the small stream trickling down through breakdown in Rafinesque Hall of Mammoth Cave, or the small domepits near the entrance of Great Onyx Cave). In the streams they are encountered crawling on the bottom muds or floating on the surface film. In intermittent pools the flatworms probably survive periods of dryness by "encystment" between layers of hygroscopic silt, as described for the European Fonticola notadens by Ginet and Puglisi (1964). Similar kenkiids have been observed in many other Kentucky caves, but have not been determined to species, so the ranges of $* S$. percaeca and $* S$. buchanani beyond the Mammoth Cave region are at present inadequately known.

Nematoda. - Nematode worms of undetermined family occur sporadically in the bottom muds of Crystal Lake, the Roaring River Shrimp Pools, and some of the rimstone pools sampled throughout the system. Hubbard (1880) reports a nematode parasite in larvae of the beetle * Ptomaphagus hirtus (Tellk.). Kofoid (1899) reports nematodes from an Echo River plankton sample.

Nematomorpha. - An undetermined genus and species of gordiid worm parasitizes the cave cricket Hadenoecus subterraneus (Scudder). It is rarely found in the adult stage. In Webb Cave, 30 kilometers east of Mammoth Cave, at Bear Wallow, Barren County, the same or a closely similar species was taken from the hemocoels of trechine beetles, * Neaphaenops tellkampfii (Erichson) and *Pseudanophthalmus pubescens (Horn). I have found only one other instance of nematomorph parasitism of *Neaphaenops, in a cave in Green County, Kentucky.

Rotifera. - Kofoid (1899) reports finding a single philodinid rotifer in the Echo River plankton sample he studied. Bottom muds of pools occasionally produce an elongate philodinid of undetermined genus and species; it is probably a regular inhabitant of the cave system and should be further investigated. A few monogonont rotifers, Keratella sp. and Asplanchna sp., were observed in the Echo River plankton samples, but were extremely uncommon compared with copepods and cladocerans, and apparently were more or less accidentally washed into the cave. Keratella sp. was also taken in Crystal Lake. (See p. 203). 
Oligochaeta. - Lumbricids are common in wet, rotting wood in Mammoth Cave, and in many other caves of the same region, wherever debris is washed underground by sinking streams. Gates (1959) reports Allolobophora trapezoides Duges, Dendrobaena rubida Savigny, and Eisenia foetida Savigny from Mammoth Cave; all three species are European, introduced into North America. An aquatic tubificid, Chaetogaster sp., is not uncommon in shallow, temporary pools in the bottom of domepits. This apparent troglophile has been taken in Mammoth Cave (Roosevelt Dome, domes near Frozen Niagara), Proctor Cave, and several other caves in Kentucky and Tennessee. Another tubificid, undescribed sp., is very common in wet silt along the banks of underground streams of Mammoth Cave and numerous other caves of the region. The castings of these tiny, fragile worms are present in immense quantity along Styx River, Lake Lethe, and Roaring River, although the worms themselves must be sought by sifting and straining large quantities of wet mud. These tubificids, which apparently feed on bacteria in the silt, constitute an important food source for riparian species of trechine beetles. Tubifex tubifex was encountered in large colonies in the sewage-polluted stream in Horse Cave, Hart County.

Gastropoda. - The troglobitic snail *Antroselates spiralis Hubricht (1963) is known only from Echo and Roaring rivers, Echo River Spring, Stillhouse Hollow Cave (Mammoth Cave National Park), a cave stream in Cedar Sink, and a single cave in Crawford County, Indiana. In Mammoth Cave, where it is not common, it occurs only under large stones in shallow riffles. Although Hubricht (1963) referred * A. spiralis to the Hydrobiidae, Taylor (1966) states that it is not a hydrobiid but may possibly belong in the Micromelaniidae, subfamily Emmericiinae. Goniobasis laqueata Say (Pleuroceridae), a trogloxene, has been found in many caves and springs in the Interior Low Plateaus, including caves of Logan und Metcalfe counties, but has not yet been taken in caves of Mammoth Cave National Park. Melania latitans Anthony 1854, described from "the subterranean river flowing through Mammoth Cave," was synonymized with Lithasia obovata (Say), which occurs in Green River outside the cave, by Goodrich (1940). Neither Hubricht nor I have found Lithasia in the cave stream, however. *Carychium stygium Call (Carychiidae) is a minute $(2 \mathrm{~mm}$.), terrestrial snail which is known only from caves (Figure 9). Its retention of eyes indicates that it is a recent troglobite. *C. stygium is often common on wet cricket guano on flowstone, ledges, rotting boards, and rotting leaves. The distribution of this species is restricted to the Pennyroyal plateau from a short distance north of Mammoth Cave southward to the Tennessee border, including a single 
cave in Tennessee (Hubricht, 1963). In 1956 Hubricht drew my attention to a muddy ledge in the lowest level of Mammoth Cave, near Styx River at the Natural Bridge, where a flourishing colony of $C$. stygium occurred, remote from the usual food-rich areas (typically near entrances) where the species is normally encountered. The colony was apparently entirely fortuitous, since live snails were not observed the following year after flooding of the gallery, nor have living specimens been found at this spot since, despite frequent examination through 1966. Carychium exile H. C. Lea, a troglophile, was reported from Vance Cave at Park City, Barren County (Hubricht, 1964). Three species of Helicodiscus (Endodontidae) have been discovered in the caves of the Mammoth Cave area. H. (Pseudiscus) punctatellus Morrison (*?), a troglophile or possible troglobite, is known only from dead shells in White Cave. *H. (Troglodiscus) hadenoecus Hubricht (1962) known from Beckton (= Tar Barrel) Cave, Barren County, ranges southward to caves of Tennessee and Alabama. A peculiar form of $H$. notius, described by Hubricht (1962) as H. n. specus, is known only from Burnet Cave at Park City; Hubricht (in litt.) now thinks that specus may be only "a somewhat degenerate form" of $H$. notius. The polygyrid snail Mesodon (Patera) a. appressus (Say) is a common threshold trogloxene in White Cave, Buzzard Cave (on Flint Ridge below entrance to Floyd Collins' Crystal Cave), and Great Onyx Cave. $M$. (Inflectarius) inflectus (Say) was found by Hubricht (1964) in Ronalds and Cooch Webb caves, Hart County, and Duval Saltpeter Cave (near Beckton), Barren County. Giovannoli (in Bailey, 1933) reports finding Stenotrema hirsutum (Say) along Echo River, where it was apparently an accidental. Zonitoides arboreus (Say) (Zonitidae) is the most common snail in the Mammoth Cave system other than *C. stygium. A troglophile which is invariably associated with rotting timbers or rotting leaves, it has been found in remote parts of Mammoth Cave, and in White, Buzzard, and Vance caves. Another zonitid, *Glyphyalinia (Glyphyalus) specus Hubricht (1965), a troglobite, occurs in White, James, and Beckton caves and ranges southward into the Cumberland plateau of Tennessee. G. (s. str.) cryptomphala (Clapp) is known from Thomas Cave, near Hadley, Warren County, where it is probably a troglophile.

Cladocera. - A single cladoceran, Bosmina longirostris O. F. Müller, (det. H. C. Yeatman), was encountered in considerable numbers in a plankton sample taken in Echo River on 7 July 1963, shortly after a summer rise in Green River which carried surface waters into the cave.

Copepoda. - Sixteen species of copepods have been recorded from the streams and pools of the Mammoth Cave system, but the majority 
of these are common epigean species not restricted to caves. Some are probably troglophiles, but others are doubtless accidental, having washed into the cave from Green River. Two previous reports on the copepods of Echo River are those of Kofoid (1899), based on a sample taken by C. H. Eigenmann in December, 1898; and Chappuis (1931), based on a sample taken by C. Bolívar and R. Jeannel in autumn, 1928. Plankton tows of Echo River were made by R. A. Kuehne and T. C. Barr, November and December, 1961, and by Barr in July, 1963; and of the Roaring River Shrimp Pools by Barr, April 1962. In addition, a small sample of copepods was obtained from Wandering Willie's Spring (Barr). Three cyclopoids and two calanoids were added to the known copepod fauna of Mammoth Cave, and a mutilated specimen of a possibly undescribed harpacticoid was noted in the Roaring River sample. I am especially indebted to H. C. Yeatman for determination of these specimens and for comments on the taxonomic status of species previously reported by Kofoid and Chappuis.

\section{Suborder Cyclopoida}

Tropocyclops prasinus (Fischer, 1860)

River Styx (Barr \& Kuehne); Echo River (Barr); Roaring River (Barr); also reported from Echo River by Chappuis.

Cyclops (Acanthocyclops) vernatis Fischer 1853

Echo River (Barr); Roaring River (Barr); recorded from Echo

River by Kofoid as $C$. viridis americanus Marsh (syn.) and $A$. robustus Sars forma setiger Thallwitz (syn.) by Chappuis.

Cyclops (Acanthocyclops) exilis Coker 1934

Wandering Willie's Spring in Mammoth Cave; 5 specimens extracted by pipette from bottom silt (Barr).

*Cyclops (Megacyclops) donnaldsoni Chappuis 1929

Roaring River; one specimen in 5th copepodid stage (Barr). Known only from cave streams in Indiana, Kentucky, and Tennessee.

Cyclops (Diacyclops) bicuspidatus subsp.

Recorded from Echo River by Kofoid; probably C. b. thomasi S. A. Forbes 1882.

Mesocyclops edax (S. A. Forbes, 1891)

Echo River (Barr); also reported from Echo River by Chappuis.

Macrocyclops fuscus (Jurine, 1820)

Echo River (Barr).

Macrocyclops albidus (Jurine, 1820)

Echo River, recorded as C. albidus by Kofoid. 
Eucyclops agilis (Koch, 1838)

Echo River (Barr), also recorded from Echo River as C.serrulatus (syn.) by Kofoid and as E.serrulatus Fischer (syn.) by Chappuis.

Eucyclops speratus (Lilljeborg, 1901)

Reported from Echo River as E. elegans (Herrick) by Chappuis; E. elegans is a nomen dubium.

?Paracyclops fimbriatus poppei (Rehborg, 1880)

Chappuis reported $P$. finitimus Kiefer 1928 from Echo River, probably an error (Yeatman, in litt.). P. finitimus is found only in Africa and New Zealand and is easily confused with P. fimbriatus poppei, which occurs in seeps and springs and is common inside and outside of caves in America.

\section{Suborder Harpacticoida}

* Attheyella pilosa Chappuis 1929

Reported from Echo River by Chappuis; the type locality is Mammoth Cave. Taken in large numbers as ectocommensals on the crayfish *Orconectes inermis inermis Cope in Cub Run Cave, Hart County (Barr). Probably a troglobite; may be identical with Canthocamptus cavernarum Packard nom. dub.

Bryocamptus morrisoni elegans Chappuis 1929 (*?)

A single specimen was taken from Horse Cave (type locality), Hart County, by Bolívar and Jeannel. It may be only a variation of B.morrisoni.

Gen. et sp.

One damaged specimen of an undeterminable harpacticoid was obtained in a plankton tow in Echo River. Additional specimens have not yet been discovered.

Suborder Calanoida

Diaptomus pallidus Herrick 1879

Roaring River (Barr); Echo River (Barr \& Kuehne).

Diaptomus sp.

A single mutilated individual was reported from Echo River by Kofoid.

Osphranticum labronectum S. A. Forbes 1882

Echo River (Barr).

Ostracoda. - Klie (1931) reported a single specimen of Candona sp. (?*) from a small plankton sample taken in Echo River by Bolívar 
and Jeannel in 1928. Kofoid (1899) found 2 specimens of "Limnocythere sp." in Eigenmann's plankton sample from the same stream. Our own samples produced no free-living ostracods. Two troglobitic ostracods of the family Entocytheridae occur in Mammoth Cave as ectocommensals on the cave crayfish *Orconectes pellucidus Tellkampf*Sagittocythere barri (Hart and Hobbs, 1961) and *S. stygia Hart and Hart (1966). * $S$. barri is known from about 25 collections from 22 caves in Indiana, Kentucky, Tennessee, and Alabama, including collections from Echo River, Styx River, and Lake Lethe in Mammoth Cave. Cambarus tenebrosus Hay is an occasional host for this species. Hart and Hart (1966: p. 8) comment: "Of the 11 supposedly troglobitic entocytherid species that have been reported from the United States... $S$. barri is represented in more collections than any of the others, and without exception has been found only in subterranean waters. Furthermore its range corresponds with that of the hypogean representatives of the crayfish genus Orconectes... and it appears likely that this ostracod is found exclusively on this group of crayfishes." * Sagittocythere stygia, however, is known only from the holotype male, taken from *Orconectes pellucidus in the River Styx, Mammoth Cave. It is apparently closely related to $* S$. barri.

Isopoda. - The widespread *Asellus stygius (Packard), first described from Mammoth Cave and subsequently found in caves and springs of southern Illinois, Indiana, and other parts of Kentucky, is common in shallow, flowing waters throughout the Mammoth Cave system. It rarely occurs in pools unless they are near a stream. A trogloxene asellid, Lirceus fontinalis Rafinesque, was found by Leslie Hubricht at the spring outlets of Echo and Styx rivers. Hay (1903) found this species (reported as Mancasellus macrourus Garman, a junior synonym) in Echo River, where it probably occurred as an accidental. Two terrestrial isopods of the family Trichoniscidae occur in the caves as troglophiles. Haplophthalmus danicus Budde-Lund 1885 is common in Mammoth Cave, where I found it on wet wood in Cathedral Domes and Roosevelt Dome, and is known from various other caves in the United States, including Luray and Massanutten Caverns, Virginia; Carlsbad Caverns, New Mexico; Grand Caverns, Tennessee; and Barnes Smith Cave, Hart Co., Kentucky (Vandel, 1965). Miktoniscus mammothensis Muchmore (1964), described from Cedar Sink and White Cave, is occasionally abundant on cave cricket guano and rotting vegetation from cave rat nests near the entrance to White Cave. Troglobitic trichoniscids are numerous in caves of southern Europe, the Appalachian valley, and Texas, but are thus far unknown from caves of the Interior Low Plateaus. (See p. 203). 
Amphipoda. - Two troglobitic species of Gammaridae, *Stygobromus sitreus Cope (1872) and $* S$. exilis Hubricht (1943) were first described from Mammoth Cave. $* S$. exilis is the more abundant and more widespread of the two, ranging southward along the Pennyroyal plateau and occurring over most of central Tennessee. $* S$. vitreus is known from Mammoth Cave and at least 3 localities in Middle Tennessee (Davidson, Van Buren, and Warren counties). Neither species seems to occur north of Mammoth Cave, or to the southeast across the Cumberland saddle. In these areas (to the north and southeast), Stygobromus is replaced by *Crangonyx packardi S. I. Smith, a widespread form which may represent several closely related species (J. R. Holsinger, in litt.). *Stygobromus spp. typically occur in small backwater or residual pools, rimstone pools, and films of water trickling over breakdown. Hubricht (in litt.) found $* C$. packardi "in the spring on the cliff above River Styx Spring and in streams in caves on the north side of Green River." The only other amphipod reported from Mammoth Cave National Park is a non-cave species, Crangonyx obliquus (Hubricht \& Mackin), which Hubricht (in litt.) found in a spring near Houchins' Ferry. (See Addenda, p. 203).

Decapoda. - Two species of crayfishes and one species of atyid shrimp inhabit the Mammoth Cave system. *Orconectes pellucidus (Tellkampf, 1844) (Fig. 10) is relatively common in the rivers (Styx, Lake Lethe, Echo, Roaring River) in the lower level of Mammoth Cave, as well as in streams of the Flint Ridge cave system, the Cedar Sink system, and many other caves of the Pennyroyal plateau (westward to Trigg County, Kentucky). The adherence of organic matter to the exoskeleton may give a dark or almost black color to occasional specimens, but they are readily distinguished by the slender form and the greatly reduced, non-functional eyes. The Indiana cave crayfish, *Orconectes inermis inermis Cope, replaces *O. pellucidus immediately north of Mammoth Cave in the Pennyroyal (Hobbs and Barr, in preparation), and $* 0$. australis packardi (Rhoades) occurs in caves at the margin of the Cumberland plateau in Rockcastle, Pulaski, Wayne, and McCreary counties, Kentucky, but troglobitic Orconectes are absent from the intervening areas in south-central Kentucky ("Cumberland saddle slope"). Cambarus tenebrosus Hay (1902), a troglophile, is rather rare in Mammoth Cave but often abundant in other caves of the Interior Low Plateaus, where it may attain large size. In our investigations a few specimens have been encountered in Roaring River and Lake Lethe. The atyid shrimp, * Palaemonias ganteri Hay (1903) (Fig. 11), during 12 years of investigations on the biology of the Mammoth Cave system has been encountered only in the "Shrimp 
Pools" of the Roaring River passage (where W. P. Hay first saw the species), about 75 to 175 meters from Silliman Avenue, and in the Golden Triangle area in the lower levels of Crystal Cave in Flint Ridge. The cave guides report that shrimps were formerly occasionally seen in a pool near the Fourth Landing on Echo River. The Shrimp Pools in the Roaring River Passage are residual flood pools approximately 3 meters higher than low water level in Roaring and Echo rivers. The only other troglobitic atyid known from the United States is $* P$. alabamae Smalley (1962), from Shelta Cave at Huntsville, Alabama.

Chelonethida. - Three species of pseudoscorpions inhabit the Mammoth Cave system. * Pseudozaona mirabilis Banks (1895) (Chernetidae) described from Indian Cave, Barren County (on the road between Mammoth Cave and Cave City), is usually regarded as a troglobite, but it always occurs near entrances and may well be a troglophile. In the Mammoth Cave system it is common in White Cave, in rotting leaves of old cave rat nests. *Kleptochthonius (Chambertinochthonius) hageni Muchmore (1963) (Chthoniidae) (Fig. 12) was confused with * K. packardi (Hagen) from Wyandotte Cave; it is known from Mammoth and Long caves in Mammoth Cave National Park. * K. cerberus Malcolm and Chamberlin (1961) is found on guano-coated flowstone in White Cave. The two species must certainly occur in several caves of the Park together, despite the fact that additional determinations of Kleptochthonius from these caves have not been made since description of these species. Probably they do not range very widely, since surrounding caves seem to be inhabited by different species of Kleptochthonius (Chamberlinochthonius) - *K.(C.) microphthalmus Malcolm and Chamberlin (1961) from Thomas Cave, near Hadley, Warren County; *K. (C.) attenuatus Malcolm and Chamberlin (1961) from Barnes Smith (= "Blind Snail") Cave, Hart County; *K. (C.) hubrichti Muchmore (1965) from Duval Saltpeter and Beckton caves, Barren County; and other, probably new but still undescribed species from the south Pennyroyal and the Cumberland saddle slope. Apochthonius moestus (Banks), a trogloxene, occurs with a troglobitic Kleptochthonius sp. in Copelin Cave, northwest Hart County. Both of the Mammoth Cave system species (*K. cerberus and *K. hageni) have 2 anterior eyes, while $* K$. packardi from Wyandotte Cave has no eyes. Since these three species were confused by Packard (1888), the eye variability he described is partially explained, although specimens from the Labyrinth were said to be "totally blind, with no traces of eyes." Collembolans appear to be a frequent food for chthoniids in caves, and these pseudoscorpions have occasionally been observed carrying a collembolan in one of their chelae. The Mammoth Cave 
chthoniids are seldom very abundant, and generally occur in mesic areas not subject to flooding, e.g. on wet flowstone in White Cave and on the dry fill at the end of Dixon Cave.

Opitiones. - Leiobunum longipes Weed (Phalangiidae) is a common threshold trogloxene in Buzzard Cave and other small caves of Mammoth Cave National Park. Masses of 50 to 75 hibernating individuals occasionally aggregate on walls or ceilings of low stream crawlways, seldom far beyond an entrance. When disturbed, such masses pulsate rhythmically and synchronously. *Phalangodes armata Tellkampf (1844) (Fig. 13) (Phalangodidae) is a troglobitic opilionid found from Mammoth Cave along the Pennyroyal to the vicinity of Bowling Green. It does not extend farther south or north along the Pennyroyal, nor southeast into the Cumberland saddle slope. The eye tubercle is devoid of pigment, and the elongate, second pair of legs serve an antenna-like function. Although not rare, *P. armata is seldom abundant. One or more specimens may usually be found in the Labyrinth, in River Hall, in the rocks at the bottom of Rafinesque Hall, or in the Radio Room of Mammoth Cave. In June, 1962, about 25 individuals were observed in a low, wide, silt-floored, bedding-plane crawlway at the end of the main passages in Colossal Cave (in Flint Ridge).

Araneae. - The most conspicuous spider in Mammoth Cave is the cave orb weaver, Meta menardi Latreille (Argiopidae) (Fig. 14). Normally this species is a threshold trogloxene, spinning its webs not far from cave entrances at the inner edge of the crepuscular zone, as in White and Buzzard caves. In Mammoth Cave, however, it has proved itself a facultative troglophile and has become established at remote sites near trash cans beside the tourist trails near (and far beyond) Snowball Dining Room. Food scraps thrown into the trash cans attract and maintain small populations of dipterans (Bradysia sp., Megaselia cavernicola Brues, Leptocera tenebrarum Aldrich) which are eaten by the spiders. M. menardi is widespread, being known in many other caves of the United States and even caves of western Europe. Keyserling (1881) originally described the common Araneus casaticus, another argiopid, "aus den Höhlen in Kentucky"; this species spins its webs about barns and other buildings and under cliffs, as at the entrance to Dixon Cave, but should not be considered a cavernicole. Achaearanea porteri (Banks) (Theridiidae) a gray comb-footed spider, has not yet been found in the immediate vicinity of Mammoth Cave, although it occurs erratically in the twilight zone of caves from southern Indiana to northern Alabama and will almost certainly eventually be found in caves of the Park. All four of the most widely distributed troglobitic spiders of the family Linyphiidae have been 
taken in the Mammoth Cave region - *Phanetta subterranea (Emerton, 1875), *Porrhomma cavernicolum (Keyserling), *Anthrobia monmouthia Tellkampf (1844a) and *Bathyphantes weyeri Emerton. All of these "species" probably represent groups of relict populations of troglophile species which have recently become extinct at the surface; they are consequently morphological species and - with the possible exception of $* P$. subterranea, which can be found in almost any cave in eastern United States south of the margin of Pleistocene glaciation and north of the Fall Line - each probably represents several separate gene pools. *P. subterranea is known from Mammoth, Indian, Lyons, Reynolds, Dixon, and Beckton caves in the Mammoth Cave region, but ranges northward and eastward to Pennsylvania and south to Alabama. The female is readily distinguished by the projecting, fingerlike epigynum. *Anthrobia monmouthia (=Antrobia or Anthrobia mammouthia auct., not Tellkampf; unjustified emendation) is abundant in Mammoth, White, Proctor, Diamond, and the Flint Ridge caves, but closely similar spiders inhabit caves of the Greenbrier valley in West Virginia, the Eastern Highland Rim, and the Cumberland plateau of Tennessee. *Bathyphantes weyeri was taken in Brushy Knob Cave, Barren County (between Cave City and Park City), but is also known from caves near Somerset, Kentucky, and caves in the Appalachian valley of Virginia. Araeoncus (Erigone) infernalis (Keyserling) was described from Reynolds Cave, near Cave City, Barren County (possibly the same as a small cave about $2 \frac{1}{2}$ miles west of Cave City and a mile south of $\mathrm{Ky}$. Rt. 70, sometimes called "Wonderland Cave"), but is a threshold trogloxene or uncommon troglophile at best. Centromerus latidens (Emerton) is an established threshold trogloxene in Buzzard Cave. Cybaeus giganteus Banks (Agelenidae) has established a troglophile population in the Frozen Niagara section of Mammoth Cave. The species is also known from New York and North Carolina. These rather large, pale-brown spiders spin irregular webs under stones and in holes in the floor. Calymmaria cavicola (Banks), another agelenid, is a threshold trogloxene in Buzzard Cave and in many other caves of the Interior Low Plateaus outside the Park area. Coras juvenilis (Keyserling, 1881) was originally described from Mammoth Cave, where it was probably taken as an accidental. A few specimens of a large fishing spider, Dolomedes scriptus Hentz, were collected a short distance inside a small stream cave in Big Hollow, Mammoth Cave National Park. Marpissa lineata (Koch) (Salticidae), known from Mammoth Cave from a single specimen taken inside New Entrance, is almost certainly a cave accidental, since salticids depend heavily on vision for capture of their prey. Liocranoides unicolor Keyserling 
(1881) (Clubionidae) was originally described from Ely Cave (location?), Kentucky, presumably located somewhere in the Mammoth Cave region. Although uncommon and consequently of relatively minor ecological importance in Mammoth Cave itself, L. unicolor is locally abundant, usually near entrances, in some caves of the region, where this troglophile is found under stones and is probably of considerable importance as a predator.

Acarina. - At least 11 families of acarines are represented in the Mammoth Cave fauna, although the taxonomic situation is highly tenuous for most of them. Packard (1888) named 6 species from the Mammoth Cave area, depending solely on Emerton's drawings for their description, and until adequate fresh material from the caves can be compared with Packard's types, about all that can be done is to guess the probable systematic position of these species. Two mites were described from Mammoth Cave by Banks (in Call, 1897). Vitzthum (1925) suggested appropriate generic assignments for the Packard species, and Holsinger (1965) redescribed the most conspicuous of these six species, *Rhagidia cavernarum. Macrocheles sp. (Macrochelidae, det. J. A. Wallwork) is a relatively large, brown mite which is phoretic on cave flies of the family Heleomyzidae; it often appears in bat guano or in meat or fish baits where these flies lay their eggs. Vitzthum thought that Packard's Gamasus (or Hypoaspis?) troglodytes was a Macrocheles. A single specimen of Gymnolaelaps sp. (Laelaptidae, det. R. W. Strandtmann) was found crawling up Frozen Niagara in Mammoth Cave; other undetermined laelaptids were found on rotten wood at Mary's Vineyard. According to Vitzthum, Laelaps(=Iphis?) cavernicola Packard (*?) could be a Hypoaspis. Two dermanyssids were reported by Giovannoli (in Bailey, 1933) - Ichoronyssus sp. from Myotis sodalis and "Liponyssus sp." from M. sodalis, M. lucifugus, and Pipistrellus subflasus. W. Russell collected a tick, Ixodes cookei Packard (Ixodidae) (det. G. M. Kohls), in James Cave, Barren County. Banks (in Call, 1897) described Linopodes mammouthia (*?) (Eupodidae) from specimens Call had collected in the Labyrinth. A single species of Rhagidia (Rhagidiidae) is common in the Mammoth Cave system, *R. casernarum (Packard); it was correctly referred from Rhyncholophus cavernarum by Vitzthum and redescribed by Holsinger (1965), who records other specimens from caves in Edmonson, Hart, and Pulaski counties, Kentucky, and from Fentress, Van Buren, and Grundy counties, Tennessee (Cumberland plateau). R. cavicola Banks 1897 is a junior synonym of *R. cavernarum. Sejus? or Zercon? sanborni Packard, from a small (sandstone?) cave on Dismal Creek northwest of Mammoth Cave, was assigned by Vitzthum to Microtrombidium. 
An undetermined trombiculid, probably Euschoengastia pipistrelli Brennan, was found on the ear of a Pipistrellus in White Cave. Three species of oribatids belonging to three different families have been taken in the Mammoth Cave system. Packard's Damaeus bulbipedata is obviously a belbid, possibly genus Belba (according to Vitzthum). and Oribata alata Packard is probably a galumnid (Galumna, according to Vitzthum); both species were taken at the back of Dixon Cave (Packard, 1888). Ceratozetes sp. (Ceratozetidae, det. J. A. Wallwork) was found in cave cricket guano in a small passage near Fairy Grotto in Mammoth Cave.

Tardigrada. - A single, undetermined tardigrade was taken in a bottom sample in Crystal Lake, Mammoth Cave.

Diplopoda. - Two species of troglobitic millipedes inhabit the Mammoth Cave system. *Antriadesmus fragilis Loomis (1943) (Fig. 15), a minute polydesmid, is fairly common on wet flowstone which is coated with cave cricket guano in White Cave. In Mammoth Cave, however, only a single specimen has been taken, near Rapier's Pit along Styx River. Much more widespread and considerably larger $(12-15 \mathrm{~mm})$ is * Scoterpes copei Packard (Fig. 16), a conotylid. In this species each of the long, curved setae on the shoulders bears a fine drop of mucous secretion of unknown function. The usual habitat of $* S$. copei is wet, rotting wood; wet flowstone covered with cave cricket guano; or wet, rotting cardboard or other debris left about in the cave. Hubbard (1880) found Scytonotus granulatus (Say), an epigean polydesmid probably best regarded as an occasional threshold trogloxene, in Indian and Lyon caves, Barren County.

Chilopoda. - Giovannoli (in Bailey, 1933) reports finding small centipedes in River Hall. Tidabius sp., a lithobiid, seems well established in this area, although it is not abundant. Specimens were obtained on rotting wood and on river gage posts in River Hall and in nearby passages - Carlos' Way and Fat Man's Misery. It is apparently a troglophile.

Collembola. - At least 13 species of collembolans inhabit caves of the arca, although only 10 of these have been taken in Mammoth Cave or the Flint Ridge system. Among the podurids, *Willemia sp. (probably undescribed and probably troglobitic) occurs on rotten boards in the Roaring River passage. Neanura sp. (probably undescribed, probably troglophilic) has been found on rotten wood in Cathedral Domes, and *Onychiurus of one or more species (probably undescribed, probably troglobitic) have been found in Mammoth and several other caves of the region. An isotomid, *Folsomia cavicola (Banks, 1897; described as Entomobrya), a probable troglobite, is the most commonly found 
collembolan in Mammoth Cave, occurring on damp wood, paper, cardboard, or other debris. The entomobryids are abundant and conspicuous in caves of the area as in most cave regions, but two troglobitic species, * Pseudsinella hirsuta (Delamare-Déboutteville) and *Sinella cavernarum (Packard) have not yet been found in Mammoth Cave National Park. *P. hirsuta occurs in caves near Bowling Green, Glasgow, Greensburg, and Elizabethtown, its distribution circling the Mammoth Cave area peripherally, also extending northeastward to Mercer County, Kentucky, and south to northern Alabama. *S. cavernarum (descr. as Degeeria by Packard) or a closely related species has been taken in Duval Saltpeter and Neals Chapel caves, Barren County, and in Barnes Smith Cave, Hart County. Packard (1888) also records it from Diamond Caverns. Tomocerus (Pogonognathellus) bidentatus Folsom is a common troglophile of the cave cricket guano community in Mammoth Cave and in a number of other caves in Barren, Hart, and Warren counties, Kentucky. T.(P.) flavescens (Tullberg), a related species, occurs in Great Onyx Cave and in Cub Run (Hart County) and Wonderland (Hardin County) caves. T. (P.) dubius Christiansen occurs in Duval Saltpeter Cave, near Beckton, Barren County. Tomocerus plumbeus var. pallidus, which Packard (1888) lists from Hundred Domes Cave (Barren County), is a synonym of $T$. flavescens (Christiansen, 1964). Pseudosinella argentea Folsom is known from Mammoth Cave and from a small cave on the south U.S. 31-W bypass in Bowling Green. P. duodecimpunctata Denis, a widespread troglophile (Christiansen, 1960 a), was found in considerable abundance by Christiansen and Barr on wooden posts in Great Onyx Cave. Two sminthurids occur in the Mammoth Cave system, both belonging to the genus Arrhopalites. *A. altus Christiansen (1966) is known only from the unique holotype, collected from a wet, rotting shirt beside the stream in Eyeless Fish Trail, in the Crystal Cave part of the Flint Ridge system. It is highly modified for cave existence, but strangely enough, has not been taken again, despite a search by Christiansen and Barr in both the Roaring River passage of Mammoth Cave and the Pohl Avenue section of the Flint Ridge system. Arrhopalites pygmaeus (Wankel), a widespread troglophile, occurs in many places in Mammoth Cave; Sminthurus mammouthia (Banks, in Call, 1897) is a synonym. (See Addenda, p. 203).

Diplura. - Two species of diplurans, one a troglobite and the other a rare troglophile or accidental, are known from the Mammoth Cave system. *Plusiocampa cookei (Packard) (Fig. 17), a campodeid, is widespread throughout the system, its usual habitats being wet flowstone and cricket guano, silty areas in the upper level galleries where 
*Neaphaenops occurs, and damp silt along the rivers. Silvestri (1934) noted that Packard's (1888) description of Campodea cookei did not agree with his figures nor with actual specimens from the caves, and redescribed this species as Plusiocampa nearctica; further descriptive notes are given by Condé (1949). Despite Packard's inadequate description, however, cookei cannot be treated as a nomen dubium unless it is subsequently demonstrated that two or more species of Plusiocampa inhabit Mammoth Cave. "Japyx" subterraneus Packard (1874), from described Little White Cave (Packard's "White Cave, Jr."), was transferred to Metajapyx by Silvestri (1947), although there is some doubt that Silvestri's specimens were actually conspecific with Packard's type (J. Pages, in litt.). Japygids were also taken in White and Crystal caves.

Thysanura. - Tellkampf (1844) described Triura cavernicola from Mammoth Cave, but no machilid has since been seen in the cave except for a specimen which Packard (1888) said "seemed immature and was mislaid." No other troglobitic machilids are known from anywhere else in the Interior Low Plateaus. A single specimen of Nicoletia sp. (Nicoletiidae) taken at the back of Beckton Cave, Barren County, is the easternmost record for this genus, but it is apparently a cave accidental.

Orthoptera. - Four species of cave crickets (Rhaphidophorinae) have been reported from the Mammoth Cave region, but only 2 of these are regular cave inhabitants. Ceuthophilus stygius (Scudder) is common near cave entrances in the twilight zone, and has been taken in a number of caves in the area. A large colony is usually found in the concrete entrance house at Great Onyx Cave. In Mammoth Cave itself, C. stygius has been taken inside a wooden telephone box at the bottom of Mammoth Dome, on the wall of an adit at the juncture of Boone and Kentucky avenues, and at the bottom of the staircase in New Discovery Entrance. T. H. Hubbell (in litt.) commented: "Ceuthophilus stygius likes rocky situations, especially those where there are microcaverns, as in talus slopes and cliffs along river valleys and ravines. I have numerous records from such situations, generally forested, in southern Indiana, Kentucky, and the Cumberland plateau of northern Tennessee." Almost all of the cave specimens of this species are medium juveniles or subadults, the mature individuals apparently rarely remaining in the caves. A single Ceuthophilus brevipes (Scudder) was taken by Bolívar and Jeannel (1931) in Horse Cave (= Hidden River Cave), Hart County (Chopard, 1931). "Although the specimen has not been seen, the adult $q$ from John and Zed (Fred) Field's Cave, near Bee Spring, Kentucky, and det. as Ceuthophilus 
sloanii Packard 1873 (Packard, 1888: p. 83) was almost certainly Ceuthophitus divergens (Scudder) - probably an accidental occurrence of this out-of-doors, forest-dwelling species" (Hubbell, in litt.). The common cave cricket of the region is Hadenoecus subterraneus (Scudder) (Fig. 18). Although it is a trogloxene, the species has a peculiarly disjunct distribution, occurring in the Pennyroyal plateau north and southwest from Mammoth Cave, in a few caves at Camp Nelson, Jessamine Co., Kentucky (type locality), and again along the western margin of the Cumberland plateau in eastern Kentucky. In late fall, winter, and early spring, H. subterraneus aggregates in favored spots inside the caves, but during warmer months of the year it is more dispersed. Beneath the "roosting sites" a thin layer of guano developsa food source of considerable importance to the cave community. Mating has been observed (Fig. 19) from August through April, but is apparently much more frequent in late fall and early winter, when the aggregations commence. Oviposition takes place on silted ledges or in silt floors of passages above flood level. Carabid beetles (*Neaphaenops tellkampfii Erichs.) often prey on eggs and first-instar juveniles. The newly hatched juveniles appear in considerable numbers in April and May, and the entire life cycle probably requires at least 2 years for completion. Natural parasites of Hadenoecus are an Isaria (probably Cordyceps sp., an ascomycete) and a gordiid worm (Nematomorpha). Park, Suter, and Reichle (in preparation) have analyzed the gut contents of a large number of specimens of $H$. subterraneus from Mammoth and White caves, and have found that the food consists largely of ants and other forest floor arthropods which the crickets obtain by feeding outside the caves at night. The guts also contained cave invertebrates, including *Neaphaenops. Crickets emerge from the caves less frequently in winter, but can be observed foraging outside on warm, wet nights.

Hemiptera. - A single specimen of a stilt bug (Neididae), Jalysus wickhami Van Duzee (det. R. I. Sailer), was taken near the entrance in Proctor Cave, either hibernating or as an accidental. Juveniles of various bugs may occur as accidentals washed into caves, but no species of hemipteran appears to be a regular cavernicole in the Mammoth Cave region.

Corrodentia. - Only one species of psocid is known to be a regular inhabitant of caves in Mammoth Cave National Park - Psyllipsocus ramburi Sélys-Longchamps (Fig. 20) occurs as a pale, wingless troglophile in rather dry areas (e.g., the Mushroom Beds in Mammoth Cave). The species occurs in European caves and in many other caves of the United States, at least as far west as Carlsbad Caverns (Barr and 
Reddell, 1967). Packard (1888) reports Liposcelis divinatoria Fab. and Hyperetes tessulatus Hagen doubtfully from Mammoth Cave, and we have not encountered these species nor any Corrodentia which might have been confused with them. Banks (in Call, 1897) described a supposedly troglobitic psocid, *Dorypteryx hageni, which Call found under wet boards in the Labyrinth; this species has not been rediscovered, and its status remains in doubt.

Lepidoptera. - In the scat piles of cave rats (Neotoma) near the mouth of White Cave, Giovannoli (in Bailey, 1933) found pupae of tineid moths (Amydria? sp.). Scoliopteryx libatrix (L.) (Noctuidae), a brown moth with orange and white markings and a characteristically emarginate outer wing margin, hibernates in White, Dixon, Buzzard, and other caves of the Park. It is known from many other caves in eastern United States and western Europe.

Diptera. - About a dozen species of flies have been reported from Mammoth Cave, but no careful study of this insect order has been made in Kentucky caves. At least half of the species probably qualify as troglophiles. Packard (1888) reports a tipulid, Ormosia (s. str.) near romanovichiana Alexander (det. as Rhypolophus near nubilus O.-S. by Osten-Sacken), from the entrance region of "a small cave near Ice Cave" (apparently 1.3 miles northeast of Northtown). Psychoda cinerea Banks (Psychodidae), the "sewer fly," is present in almost any cave where there is sewage pollution, but was also taken in White Cave. Mosquitoes occasionally hibernate in cave entrances, but the only species recorded from the Mammoth Cave region is Anopheles (s. str.) punctipennis (Say) (Culicidae), which was found hibernating in Thomas Cave, near Hadley, Warren County. Midges (Chironomidae) occur sporadically along Echo River, and Packard (1888) reports Chironomus sp. from Mammoth Cave. Larvae of an undetermined genus and species of Mycetophilidae are occasionally found in Mammoth Cave and other caves of the area, in webs under stones or on the cave walls. Bradysia sp. (Sciaridae) is common in Mammoth and many other caves of the Interior Low Plateaus; by older authors it was recorded as "Sciara sp." (Packard, 1888) or "Sciara (inconstans? Fitch)" (Giovannoli, in Bailey, 1933). Larvae inhabit piles of rotting leaves or twigs and adults are encountered flying about along the rivers in Mammoth Cave or resting under stones in places where there is a rich organic component to the substratum. Five specimens of another sciarid, Pnyxia scabiei (Hopkins), were collected at Crevice Pit. The hump-backed fly Megaselia (s. str.) cavernicola (Brues) (Phoridae) is equally common, and like Bradysia sp., is apparently a troglophile. As Giovannoli (in Bailey, 1933) remarks, this species is undoubtedly 
the "Phora rufipes" of earlier collectors and the "Phora sp." of Hubbard (1880). Leptocera (Limosina) tenebrarum (Aldrich) (Sphaeroceridae) is the third species in a trio of small flies frequently encountered in the caves of the Interior Low Plateaus, including Mammoth and nearby caves. Earlier authors called it "Borborus sp." (Packard, 1888) and Coquillet (in Call, 1897) described the Mammoth Cave population as Limosina stygia, a name now regarded as a junior synonym of $L$. tenebrarum. Leptocera is especially common on or near feces of the raccoon (Procyon lotor varius), but may also be present in the vicinity of almost any sort of decaying organic material, in which most of the dipterous larvae are probably those of this species. Flies of the family Heleomyzidae are the largest and most conspicuous of the troglophilic dipterans of the Mammoth Cave system. Although Giovannoli (in Bailey, 1933) reports the presence of Aecothea fenestralis (Fallén) in Mammoth Cave, the common species seem to be Amoebaleria defessa (Osten-Sacken) and Heleomyza brachypterna Loew. These flies rest on the ceilings of caves, often in considerable numbers, and the larger dipterous larvae of excrement and other decomposing organic matter may be those of heleomyzids. A mite, Macrocheles sp., which appears in abundance with the larvae, seems to be phoretic on heleomyzids. Giovannoli (in Bailey, 1933) reports two other species of flies from Mammoth Cave - Anthomyia? sp. (Anthomyiidae) and Cuterebra sp. (Cuterebridae), the latter present as bot fly larvae in the neck and chest of the cave rat (Neotoma).

Siphonaptera. - Giovannoli (in Bailey, 1933) recorded five species of fleas from bats and cave rats in Mammoth, Dixon, and Colossal caves. These species are discussed more fully by Fox (1940). Epitedia wenmanni (Rothschild), a hystricopsyllid, was common on Neotoma in Mammoth and Dixon caves; Giovannoli's "Phalacropsylla sp." is possibly an erroneous determination of this species, since Phalacropsylla occurs in the far west, is the only hystricopsyllid mentioned, and neither E. wenmanni nor a synonym are listed by Giovannoli. Two dolichopsyllids were also found on Neotoma - Orchopeas (= Myoxopsylla) sexdentatus pennsylvanicus (Jordan) and "Ceratopsyllus sp.," which is possibly Nosopsyllus fasciatus (Bosc), a species for which Neotoma is a rare host. Two bat fleas of the family Ischnopsyllidae were reported -Eptescopsylla (= Nycteridopsylla) chapini (Jordan) on Myotis sodalis in Colossal Cave; and Myodopsylla insignis (Rothschild), the commonest bat flea in eastern America, on Myotis lucifugus in Mammoth and Colossal caves and on Neotoma in Mammoth Cave. Fleas are often abundant in caves inhabited by mammals, but are not cave-restricted. 
Coleoptera. - Six species of troglobitic trechines (Carabidae) inhabit the Mammoth Cave system (Barr, 1967). *Neaphaenops tellkampfii (Erichson, 1844) (Fig. 21), the largest and most abundant species, was discovered by Tellkampf on an early tour through the cave, and was the second species of cave trechine to be described (the first being Anophthalmus schmidti Sturm 1844 from Carniola). *N.tellkampfii, a distinctive aphaenopsian beetle, is probably derived from an ancestor similar to * Pseudanophthalmus pubescens, judging from the morphology of the transfer apparatus of the male genitalia. It roams widely throughout the cave system in damp, but not necessarily wet, silty areas in upper galleries, as well as occasionally along the cave rivers and in wet places near domepits and breakdowns. The larvae, described by Packard (1888), apparently burrow deep in the silt, and are occasionally discovered under rocks in such areas (I have found them in Mammoth, Salts, and Great Onyx eaves). Pupation takes place in small earthen cells about $10 \mathrm{~mm}$ in diameter, excavated in moist, crumbly silt on the underside of rocks. *Neaphaenops preys readily on the eggs and recently hatched juveniles of Hadenoecus subterraneus, which explains its abundance in parts of the cave where no obvious food is evident. Its food is not limited to Hadenoecus eggs and nymphs, however, but also includes small oligochaetes and arthropods of appropriate size. Like *Aphaenops, *Darlingtonea, and other relatively large cave trechines, it burrows extensively, throwing out the silt with the metatarsi. 'The geographic distribution of this species includes all of the Pennyroyal and adjacent caves of the Mammoth Cave plateau from Breckinridge, Meade, and Hardin counties southward through the Mammoth Cave region to the vicinity of Franklin (Simpson County); its range also extends eastward along the Green River valley into central Green County and northwest Metcalfe County. Five species of * Pseudanophthalmus inhabit the Mammoth Cave system. The two most abundant, $* P$. menetriesii and $* P$. striatus, were collected and described by Motschulsky (1862). *P. menetriesii is far more abundant on wet, rotting wood and other debris in the upper levels of the cave, while $* P$. striatus, a closely similar species with identical male genitalia, is normally a riparian species, apparently feeding predominantly on tubificids. The latter beetle is abundant along Lake Lethe, Echo River, and Roaring River, but is extremely rare in upper levels of the caves. *P. pubescens Horn (1868) was first described from Cave City Cave (= Railroad Cave) on the sinkhole plain, but I have found it at the top of Mammoth Dome and near Moonlight Dome, at opposite ends of Mammoth Cave, and in Cedar Sink in the western part of Mammoth Cave National Park. It occurs 
in Mammoth Cave sporadically, but is usually very abundant in caves of the sinkhole plain. In Cave City Cave, Diamond Caverns, and Walnut Hill Cave all four of these species occur intermingled, crawling about along the banks of small subterranean pools and streams. All four species attain eastern Hart County and the Bowling Green area, but $* P$. menetriesii quickly drops out of the combination to the east. * P. audax (Horn, 1883) was described from Ronalds Cave, in Hatcher Valley near Cave City (Barr, 1959a), but was not seen again until 1962, when I collected a specimen in White Cave. A second specimen was taken in 1965 in the same spot. *P. inexpectatus Barr (1959b) is known only from a wet crevice near the top of Mammoth Dome in Mammoth Cave, from the back end of White Cave, and from Great Onyx Cave. $* P$. audax has been taken only in the dry season, while $* P$. inexpectatus is seldom found except during the wettest time of the year. One species of pselaphid, *Batrisodes (Babnormodes) henroti Park (1956) (Fig. 22), is known from the Mammoth Cave system. It is abundant in the front part of White Cave, under rocks and rotten leaves, and on rotting cardboard in Diamond Caverns. A few specimens were taken in Vance Cave at Park City (type locality), and a single specimen was found under an old newspaper in Mammoth Cave (in the Radio Room). *B. hubrichti Park occurs in Beckton Cave, Barren County, and unnamed populations of pselaphids from other caves at a radius of 25 to 35 kilometers from Mammoth Cave are apparently specifically or at least subspecifically distinct, so the geographic distribution of $* B$. henroti is probably quite restricted. * Ptomaphagus (Adelops) hirtus (Tellkampf, 1844), a blind catopid beetle, is abundant on cave cricket guano, excrement, and rotting meat scraps thrown about the cave. It is readily attracted by meat, fish, or cheese baits, and larvae appear in the baits in 3 or 4 weeks. The species ranges from northwest Hart County through the Mammoth Cave area to Bowling Green, and east to Wisdom, in Green County, and Slick Rock, Barren County. Three species of carabids are occasional troglophiles in the Mammoth Cave system and in most caves of the Interior Low Plateaus - Agonum tenuicolle LeConte, Atranus pubescens Dejean, and Bembidion lacunarium Zimmerman (Barr, 1964b). None of these species has been taken in Mammoth Cave itself, but all occur in nearby caves. Among the staphylinids, Quedius cf. capucinus Gravenhorst occurs in cave rat dung in White Cave; Lesteva pallipes LeConte occurs in a small stream cave in Big Hollow, Mammoth Cave National Park; and Atheta sp. has been taken in Dixon Cave (Packard, 1888) and in debris along the rivers in Mam- 
moth Cave. Hatch (1933) records a troglophilic catopid, Catops gratiosus Blanchard, from Lyons Cave, Barren County. (See p. 203).

Teleostei. - The fishes of Echo, Styx, and Roaring rivers include two troglobites and two habitual trogloxenes, in addition to occasional trogloxenes and accidentals. Much the same assemblage of species has been encountered by different investigators for the past century. Tellkampf (1845) gave a description of one of the amblyopsid cavefishes and mentioned seeing a "mud-fish". Putnam (1872) presented careful and more detailed observations on the amblyopsids, described a trogloxene amblyopsid, and noted the presence of other fishes in the cave streams. Notes in the papers of Eigenmann (1909), Bailey (1933), Poulson (1963), and others refer to the Mammoth Cave teleost fauna, and additional data are given by Woods and Inger (1957), Barr and Kuehne (1962), and Kuehne (1966). Three species of Amblyopsidae are found in the cave - *Amblyopsis spelaea DeKay 1842 (Fig. 23), * Typhlichthys subterraneus Girard 1860 (Fig. 24), and Chologaster agassizi Putnam 1872. Mammoth Cave is the southern limit of the known range of $* A$. spelaea and Horse Cave (= Hidden River Cave) seems to be the northern limit of the range of $* T$. subterraneus, at least in the Pennyroyal. The two species consequently overlap in the Mammoth Cave region. In Mammoth Cave itself, * Amblyopsis is rarely found except in the deeper, undisturbed pools in the upper reaches of Roaring River; large individuals apparently prefer the deepest pools, and the juveniles congregate around the mouths of underground tributaries, probably for feeding purposes. * Typhlichthys is more common in the shallow pools of Roaring River, occasionally in Echo River in the fall after the tourist season, and in smaller, more rapidly flowing streams in caves of the Pennyroyal. *T. osborni Eigenmann (1905), originally described from Hidden River (= Horse) Cave, is a synonym of *T. subterraneus (Woods and Inger, 1957). The "mudfish" mentioned by Tellkampf was probably Chologaster agassizi Putnam, which is common in Lake Lethe in the fall. Although is it a common inhabitant of smaller caves streams, springs, and sinkhole ponds, there is considerable evidence that $C$.agassizi is not capable of feeding and reproducing successfully in caves; Poulson (1963) also reports a possible endocrinological barrier to cave colonization in this species. The Lake Lethe specimens are usually in poor condition, more or less emaciated, and have empty guts (Kuehne, 1966). C.agassizi ranges into southern Illinois and southward to Tennessee and Alabama; $C$. papilliferus Forbes is a synonym, and references to "C.cornutus" in Tennessee and Alabama are based on erroneous determinations. One other habitual trogloxene in the rivers of Mammoth Cave as well as 
in cave streams throughout most of central Kentucky and Tennessee is a sculpin, Cottus carolinae (Gill) (Cottidae). This is the "Uranidea sp." of Putnam (1872) and the "Cottus bairdii" of Bailey (1933). Kuehne (1966) records the white sucker, Catostomus commersonii (Lacepède); the emerald and spot-finned shiners, Notropis atherinoides Rafinesque and N.spilopterus (Cope), respectively; the creek chub, Semotilus atromaculatus (Mitchell); an ictalurid, Ictalurus sp.; and a sunfish, Lepomis sp. from the waters of Mammoth Cave. Bailey's (1933) record of Notropis whippli from Echo River is possibly based on a misidentification of N.spilopterus; the ictalurid was probably I.melas (Rafinesque), the black bullhead, small individuals of which have been taken in a number of other caves in the Interior Low Plateaus; Putnam's (1872) record of "Amiurus catus" from Mammoth Cave is more likely to have been I.melas than I.catus. Kuehne (1966) has discussed the sources of these accidentals in Echo River and Roaring River. They are commonly regarded as having come from Green River through Echo River Spring, where many of the same species can be seen swimming back and forth under rock ledges. Semotilus atromaculatus, however, was twice encountered in pools in Cedar Sink, and probably washed into the system from sinking creeks on the Pennyroyal. In Echo River and Lake Lethe it is quite possible that both Semotilus and Chologaster could have been brought into the cave from sinking streams of the Pennyroyal.

Amphibia. - No troglobitic salamanders are known from Kentucky, although troglobitic Gyrinophilus spp. are known from central and southeast Tennessee and northeast Alabama, and other cave plethodontids occur in Georgia, Florida, Texas, and the Ozark plateau. As many as 9 species of plethodontids may occur around the mouths of caves in the Mammoth Cave system, but only 3 species commonly occur in total darkness and one additional, abundant, forest floor species (Plethodon g.glutinosus Green) is not infrequent in the twilight zone. Plethodon dorsalis (Cope), the zigzag salamander, is seasonally abundant in sinkholes and at the ends of shallow cave passages terminating in breakdown, as described by Hahn (1908) for the Donaldson Cave system in Indiana, and as seen in Mammoth Onyx Cave, Hart County. Eurycea longicauda longicauda (Green) occasionally is found in caves; along Echo River in Mammoth Cave, however, most of the specimens observed were starved and emaciated. Eurycea lucifuga Rafinesque (Fig. 25) is so frequently encountered underground that its common name is "cave salamander." It can be seen in almost any cave of the Mammoth Cave system with a sufficiently moist twilight zone, and was most often encountered in Great Onyx, White, 
and Buzzard caves, but also noted in Mammoth, Dixon, Great Salts, and Crystal caves. Stomach analyses indicate that almost any moving animal is eaten - snails, millipedes, flies, and other animals of the parietal fauna of the twilight zone are found in the stomachs, along with bits of moss and limestone fragments. A toad, Bufo woodhousei foxleri Hinckley, was seen in River Hall of Mammoth Cave on one occasion. Bailey (1933) reports several amphibians from Echo River and vicinity - E.lucifuga, E. longicauda, P.glutinosus, and the pickerel frog, Rana palustris LeConte. Most of these species probably entered the cave via Echo River Spring or River Styx Spring, since they are common twilight zone inhabitants. R.palustris is frequent in cave entrances, but rarely penetrates into the total darkness zone except by accident. Hubbard's (1880) "Rana. sp." was probably R. palustris. The bullfrog, Rana catesbeiana Shaw, commonly swims several hundred meters into stream caves, but I have found no record of its being seen in Mammoth Cave.

Aves. - Birds in the Mammoth Cave region rarely penetrate into caves. The phoebe, Sayornis phoebe (Latham), builds its nest on rocks and cliffs, including the entrances to Mammoth, Dixon, Colossal, and Buzzard caves (Bailey, 1933). Turkey vultures, Carthartes aura septentrionalis Wied., occasionally nest in cave entrances, especially if the entrances open on cliffs; such a nesting habit was probably the origin of the name of Buzzard Cave, below the entrance to Floyd Collins Crystal Cave, but no nest exists there now. A screech owl, Otus asio naevius (Gmelin), was observed about 8 p.m. one summer evening flying about near the Iron Gate, 100 meters inside the Historic Entrance to Mammoth Cave.

Mammalia. - Eleven species of bats have been found in the caves of Mammoth Cave National Park, the most common being hibernating individuals of Myotis l. lucifugus (LeConte), Myotis sodalis Miller \& Allen, Pipistrellus subflasus subflasus (F. Cuvier), and Eptesicus f.fuscus (Beauvois). The first two species are found in hibernating colonies of several thousand to several hundred, notably in Long, Dixon, and Colossal caves (Fig. 26). Development of the caves for tourist purposes has undoubtedly reduced or destroyed the colonies in Mammoth Cave (noted by Rafinesque, 1832; see also photograph in Bailey, 1933, p.77), James Cave, and Hundred Domes (= Coach) Cave. The life history of M.sodalis has been recently studied by Hall (1962), who presents much material with special reference to the Mammoth Cave region. P.subflasus (Fig. 27) is typically a solitary hibernator in the Mammoth Cave system, and individuals are found scattered about in almost all sufficiently humid parts of the cave during winter. E.fuscus, also 
relatively solitary or restricted to small hibernating colonies, usually occurs in colder areas near entrances. Small hibernating and maternity colonies of the big-eared bat, Plecotus rafinesquii (Lesson), exist in several of the smaller, more isolated caves of the Park (Hall, 1963). Myotis grisescens Howell, the gray bat, is relatively rare in caves of the Park, although large to medium summer colonies existed as close as 35 kilometers south of Mammoth Cave until very recently. Two relatively rare species, Myotis keenei septentrionalis (Trouessart) and M.subulatus leibii (Audubon and Bachman), were recorded from Colossal Cave by Bailey (1933), and Hall (1961) reports Myotis austroriparius (Rhoads) from Dixon and Bat caves. The red bat, Lasiurus borealis (Müller), seems to enter caves only accidentally; dead, mummified specimens were found hanging on the wall at Mummy Valley in Great Salts Cave and in Blue Springs Branch in Mammoth Cave. The evening bat, Nycticeius humeralis (Rafinesque), was shot near the Historic Entrance to Mammoth Cave (Bailey, 1933), but was not actually found in the cave itself. W. H. Davis has recently studied the late-summer swarming phenomenon of bats at Dixon Cave (Davis, pers. comm.), when all of these species, with the exception of N.humeralis, have been taken in mist nets stretched across the mouth of the cave at night. Several N. humeralis were netted in the woods near the mouth of the cave. Jegla and Hall (1962) described fossil bat bones and guano from Chief City in Mammoth Cave. These bones apparently are the remains of a Pleistocene (Sangamon?) colony of the free-tailed bat, Tadarida brasiliensis. Neotoma magister Baird, the common pack rat or cave rat, is common in Mammoth and other caves, emerging at night to feed on scraps of food left about by tourists or (more commonly) feeding in the forest outside of the cave. Charles Darwin, in discussing loss of eyes in cave animals, mentions cave rats from Mammoth Cave:

"In one of the blind animals, namely the cave rat (Neotoma), two of which were captured by Professor Silliman at above half a mile distance from the mouth of the cave, and therefore not in the profoundest depths, the eyes were lustrous and of large size; and these animals, as I am informed by Professor Silliman, after having been exposed for about a month to a graduated light, acquired a dim perception of objects." - Origin of Species, Ed. 6 (1872).

Despite this famous passage, $N$. magister has well-developed functional eyes. Bailey (1933) cites several small mammals living around the entrances to caves of the area - the woodchuck, Marmota $\mathrm{m}$. monax (L.); the white-footed mouse, Peromyscus l. leucopus (Rafinesque); the Virginia opossum, Didelphys o. virginiana Kerr; and the 
smoky shrew, Sorex $f$. fumeus Miller, which lives in the Historic Entrance to Mammoth Cave, and may be a boreal relict. The raccoon, Procyon lotor lotor (L.) frequents caves and cave entrances, and is far more important in the ecology of smaller caves with streams and wet areas than it is in Mammoth, the Flint Ridge system, and other caves of the Park. Raccoons penetrate far into stream caves, depositing feces on rocks and ledges, supplying food for small arthropods. This food source is probably of negligible importance in Mammoth Cave, however. The red fox, Vulpes fulva (Desmarest), has not been observed in caves of the Park, but on rare occasions is known to traverse caves in Kentucky and Tennessee. Finally, it may be noted that according to legend, the Historic Entrance to Mammoth Cave was discovered sometime prior to September, 1798, by a hunter named Houchens, who chased a wounded bear into the cave. The eastern black bear (Euarctos a. americanus Pallas), formerly abundant in the Mammoth Cave region, is known to frequent caves, and perhaps the remains of its food or its feces may have contributed to evolution of the Mammoth Cave community until recent times.

\section{The Flora}

Plant life in the Mammoth Cave system includes bacteria, eumycophytes, algae, and - under electric illumination - mosses, hepatics, and ferns. Only the eumycophytes and algae have received detailed attention and are discussed below.

Henrici slides suspended for several weeks in Echo River and Crystal Lake supported a moderately heavy microbial growth, and soil samples from several parts of the cave system contained bacteria and molds although the plate counts obtained from such samples were noticeably lower in most instances than similar counts from surface soils. In a few places the limestone ceiling of the cave has been partially decomposed and is covered with a wet paste 5 to $10 \mathrm{~mm}$. thick; microscopic examination of such a paste in Turner Avenue of the Flint Ridge system and subsequent plating revealed large numbers of cocci and bacilli. Whether resolution of such ceilings is partly the result of bacterial action or entirely the result of acid surface waters seeping into the cave has not been determined. Pohl and White (1965) have postulated a role for sulfur bacteria in the oxidation of sulfides to sulfates, contributing thereby to the deposition of gypsum in cavern passages. In caves as on the surface, bacterial and fungal decomposition of organic matter plays an important role in the ecosystem. Although Ferrobacteriales were cultured in synthetic medium from 
the silt of the Shrimp Pools in Roaring River, they were not morphologically similar to Perabacterium spelei, a species described by Caumartin (1957) from caves of France; their significance in autochthonous food production is probably neitherwidespread nor quantitatively very important in the Mammoth Cave system. Faust (1949) has suggested that nitrogen-fixing bacteria are responsible for accumulation of nitrates in cave silts; the discovery of Jegla and Hall (1962) of a Pleistocene colony of the free-tailed guano bat, Tadarida brasiliensis, in Mammoth Cave raises again the older theory of nitrate accumulation through decomposition of bat guano. Extreme pollution occurs in the rivers of Mammoth Cave during flooding, when the most probable number (MPN) of coliform bacteria per $100 \mathrm{ml}$. of river water rises to more than 1600. In late fall, the residual pools of Lake Lethe have an MPN of less than 10 per $100 \mathrm{ml}$.

Limited growth of bryophytes and ferns occurs under electric illumination, particularly near fluorescent tubes. Maheu (1926a) recorded 6 mosses - Anomodon (Leskea) attenuatus, A. rostratus, Brachythecium rivulare, Eurynchium praelongum, Gymnostomum calcareum, and Mnium rostratum - and the common liverwort, Marchantia polymorpha, from the twilight zone in Mammoth, Great Onyx, and Floyd Collins Crystal Caves. The plants were described as etiolated and stunted, and lacked sporophytes.

Algae. - All of the algae identified from Mammoth Cave (except for a few doubtful references to "Protococcus") were found in, or cultured from samples made by George Claus and T. Barr on August 28, 1963. The taxonomy of these algae has been discussed in detail by Jones (1965) and Van Landingham $(1965,1966)$. The location of these stations, Claus' original notations, some supplementary remarks, and the species of algae found by Jones and Van Landingham are given below.

Station 1. "Dark bluish-green covering on rocks." Richardson Spring, in Blacksnake Avenue; dim illumination.

Nostoc minutissimum Kütz. emend Claus,

Phormidium cebennense Gom.,

Phormidium subtruncatum Woronich. fa.

Station 2. "Small, blackish patches on rocks and stalactites." Minerva's Dome, in Blacksnake Avenue; wet wall with flocculated silt; moderately strong electric illumination.

Chlorella vulgaris Beijer.,

Lyngbya pusilla (Rabenh.) Hansg. fa. tenuior Jones,

Oscillatoria subtilissima Kütz. 
Station 3. Darnall's Way; vermiculated silt on small, wet stalactites; total darkness.

No algae found.

Station 4. "Tufts of blackish-red, mucinous material on old logs." Washington's Pit; old, rotting, wooden bridge in constant drip; total darkness.

No algae found. Claus (pers. comm.) believes that the agar-like material at this station is produced by a red alga; it is probable that the filaments died and decomposed prior to the attempt to culture the sample, or for some other reason the alga could not be cultured with the media and methods employed.

Station 5. "Scrapings from speleo-clay and from the walls." Natural Bridge at the River Styx crossing; flood-deposited silt; total darkness.

Asterococcus superbus (Cienk.), Scherf.,

Phormidium cebennense Gom.,

Scenedesmus abundans (Kirchn.) Chod.

Station 6. "Mud from small ponds." Second Landing, Echo River; near the "Sahara Desert"; total darkness.

Asterococcus superbus (Cienk.) Scherf.,

Gomontiella magyariana Claus,

Microcystis stagnalis Lemm.

Station \%. "Scrapings from greenish discoloration on walls." Roaring River passage; mud deposits on walls, about 100 meters from Silliman Avenue; total darkness.

Planophila laetevirens Greneck.

Station 8. "Abundant, bluish-gray, mucous growth on rock walls." Top of metal tower in Mammoth Dome; damp but not wet rock surface, moderately well lighted.

Chrysophyta cyst.,

Oscillatoria neglecta Lemm.

Station 9. "Yellowish-white, mucous growth on rotting rug." Crevice Pit area, in adit behind railing, under constant drip, at end of Little Bat Avenue; virtually total darkness; on old, rotten rag used for cleaning, near rotting planks of wood.

Ankistrodesmus falcatus (Corda) Ralfs,

Coccomixa dispar Schmidla.

Station 10. "Mud from small ponds." Very small drip pools in Little Bat Avenue along tourist trail; dim light.

Oscillatoria clausiana Jones, 
Oocystis lacustris Chod.,

Planophila laetevirens Gerneck,

Achnanthes microcephala (Kütz.) Grun.,

Cymbella clausii VanLandingham,

Cymbella gerloffi VanLandingham,

Cymbella hohnii VanLandingham,

Cymbella prostrata (Berkl.) Cleve,

Diatoma vulgare Bory,

Fragilaria sp.,

Gomphonema lanceolatum (Ehr.) var. insignis (Greg.) Cleve,

Gomphonema cf. parsulum (Kütz.) Grun.,

Pinnularia sp.,

Stauroneis sp.,

Synedra ulna (Nitsch.) Ehr. var. oxyrhynchus (Kutz.) van Heurck.

Station 11. "Wall scraping of blackish, layered, corrugated material." Broadway, near entrance; dry wall, dim light.

Oscillatoria subtilissima Kütz.

Station 12. "Heavy bluish-green growth on walls around a lamp." Broadway, near entrance to cave.

Ankistrodesmus falcata (Corda) Ralfs,

Beggiatoa alba (Vauch.) Trev.,

Chrysococcus klebsianus Pasch.,

Harpochytrium hyalothece Lagerh.,

Kirchneriella lunaris (Kirchn.) Möb.,

Oscillatoria animalis Ag.,

Scenedesmus abundans (Kirchn.) Chod.,

Tetrachloris inconstans Pasch.,

Trachelomonas verrucosa Stokes,

Ulothrix tenerrima Kütz. fa.,

Melosira granulata (Ehr.) Pralfs var. angustissima Mull.,

Melosira varians Ag.,

Meridion circulare (Greville) Ag.,

Synedra rumpens Kütz.

Station 12a. "Branching red growth on old log." Broadway, saltpeter workings.

Lemanea torulosa (Roth.) Ag.

(This red alga is listed erroneously in Jones' chart as L. fluviatilis Ag. but is given correctly in the systematic account.)

A smaller, but rather different algal flora was described by Nagy (1965) from Floyd Collins' Crystal Cave, a formerly commercialized portion of the Flint Ridge system. His results are as follows: 
Station 1. Heavy, grass-green growth around a lamp on a relatively dry wall surface close to the ceiling. About 400 meters from the entrance, along old "Route 1" not far beyond Floyd Collins' grave.

Neochloris minuta Arce et Bold (virtually pure culture).

Station 2. Extensive dark gray, mucous growth in crevices of wall, wetted constantly by seeping water. About 450 meters from the entrance along "Route 1."

Chamaesiphon gracilis Rabh.,

Oscillatoria neglecta Lemm.,

Scenedesmus brasiliensis Bohlin,

Asterocystis smaragdiana (Reinsch) Forti.

Station 3. Whitish, fungal (?) growth on small stalactites or stalagmites. About 550 meters from the entrance, near the Devil's Kitchen.

Oscillatoria neglecta Lemm.,

Nasicula mutica Kütz. var. niøalis Kütz.

Jones, VanLandingham, and Nagy (op. cit.) all note that the algal floras of the few caves that have been appropriately sampled in various parts of the world exhibit certain properties in common (1) the composition of species differs rather markedly from cave to cave, and (2) the floras are not readily derivable from existing algal floras at the surface in the cave region. The bacillariophyte, Navicula mutica var. nivalis, for example, found by Nagy at Station 4 in Crystal Cave, is apparently a glacial relict which has survived in the cave since a much colder epoch. In conclusion, the algae now existing in Mammoth Cave include a number of widespread, common species, but also certain psychrophilic species which have probably existed in the cave for thousands of years, at least since the retreat of the Wisconsin ice sheet. Growth of these algae in the cave is presumably heterotrophic. Near electric lights some small amount of light energy conversion probably takes place, but in most cases the cave algae are dependent on other energy sources.

Eumycophyta. - Most of the information available on the true fungi of Mammoth Cave is to be found in the papers of Call (1897) and Maheu (1926a, 1926b). Mucor mucedo is common on a number of substrates throughout the system. The cave cricket, Hadenoecus subterraneus (Scudd.), is parasitized by an Isaria sp. which Call determined as I. (Sporotrichum) densa Link, mixed with I. (S.) flasissimum Link. These presumed pathogens of Hadenoecus are probably the imperfect stages of one or more species of Cordyceps, many of which are known to have an Isaria stage. Another Isaria sp. is common on dung piles of the cave rat (Neotoma). Brashear, Wiseman, and Barr 
(1967) reported the presence in Mammoth Cave of a psychrophilic yeast which has many of the characters of Candida albicans; this yeast grows well at $20^{\circ} \mathrm{C}$., but not at $37^{\circ} \mathrm{C}$., and is apparently non-pathogenic to mammals. It commonly occurs on meat or fish baits, dead Neotoma, and dead Hadenoecus. Another species of Candida was isolated from the Shrimp Pools in the Roaring River passage. Laboulbenia subterranea, an ascomycete, parasitizes troglobitic carabid beetles, notably *Pseudanophthalmus menetriesii, *P. striatus, and *P. pubescens. This species was first described from *P. menetriesii taken in Mammoth Cave (Thaxter, 1895). Call (1897) records a number of molds from Mammoth Cave - Microascus longirostris Zukal, Zasmidium cellulare Fr., Gymnoascus setosus Eidam, G. uncinatus Eidam, two other Gymnoascus spp., Coemansia sp., Papulospora sp., and Bouderia sp. The majority of these species seem to have been taken in Washington Hall, near the present site of Snowball Dining Room, on food and paper scraps. Among the larger eumycophytes growing in the cave, Call (1897) and Maheu (1926b) list Peziza sp., Radulum sp., Trametes odorata, Coriolus micaceus, Flammula sp., Mycena sp., Paxillus panuoides, and Coprinus micaceus. C.micaceus is commonly seen in River Hall and near the Third Landing on Echo River, where its fruiting bodies - pale brown mushrooms - appear sporadically and often prolifically. The species is one of the few larger fungi which seem capable of fruiting in the cave, and has been established along the rivers for nearly a century, if not longer. Call noted the presence of Fomes (Polyporus) applanatus Pers. on rotting wood in the cave. The sterile mycelia of the genus Rhizomorpha (Fig. 28) which grow on bits of rotting wood and spread outward across the floor and walls of the cave passages probably are the mycelia of this or a similar species of polypore. According to Maheu (1926b), the mycelia Ozonium auricomum and O.aurium are associated with Coprinus micaceus and Flammula sp., respectively.

\section{Zoogeographic Relationships}

The Mammoth Cave assemblage of animal species is part and parcel of the cave fauna of the Pennyroyal plateau, a narrow karst plain sometimes called "the Land of Ten Thousand Sinks" (Jillson, 1923). Faunal components change slowly as one moves from Mammoth Cave southwest along the Pennyroyal to Bowling Green; more conspicuously along the Pennyroyal to the north, where one crosses the sandstone-capped "Hart County Ridge"; and rather abruptly to the east, 
where the massive, blue-gray St. Louis limestone gives way to the thin, dark-gray, often silty beds of the Salem and Warsaw limestones.

Four regional cave faunas may be distinguished in Kentucky (Figure 1, Table 1) - (I) the Pennyroyal fauna, (II) the Bluegrass fauna, (III) the Cumberland saddle fauna, and (IV) the Cumberland plateau

Table 1

The Regional Cave Faunas of the Interior Low Plateaus

I. Pennyroyal fauna

A. Bedford fauna - Monroe and Lawrence cos., Indiana

B. Corydon fauna - Orange Co., Indiana, to Ohio River

C. Breckinridge fauna - north Pennyroyal plateau from Ohio River to northern Hart Co., Kentucky

D. Mammoth Case fauna - south Pennyroyal plateau from the Hart County Ridge to limit of Green/Barren River basin

E. Hopkinsville fauna - west Pennyroyal plateau from Logan Co., Kentucky, west to the Ohio River, including parts of Sumner, Robertson, Montgomery, and Stewart cos., Tennessee

II. Bluegrass fauna
A. Muscatatuck fauna - southeast Indiana
B. Cincinnati fauna - southwest Ohio
C. Lexington fauna - the Bluegrass of Kentucky

III. Cumberland Saddle fauna

(The Salem-Warsaw-Fort Payne plateau of south-central Kentucky and north-central Tennessee)

A. Greensburg fauna - Green, Taylor, northern Adair cos., Kentucky

B. Tompkinsville fauna - Monroe, Cumberland, southern Barren, and southern Metcalf cos., Kentucky, and Clay Co., Tennessee

IV. Central Basin fauna

V. Cumberland Plateau fauna

A. Carter fauna - Carter, Elliott, Menifee cos., Kentucky

B. Poxvell fauna - Powell, Estill, Lee cos., Kentucky

C. Rockcastle fauna- Jackson, Rockcastle, Pulaski, Wayne, McCreary, and Clinton cos., Kentucky

D. Caney Fork fauna - Cumberland River drainage of the Eastern Highland Rim and Cumberland plateau from Tennessee-Kentucky border southwest to Caney Fork-Elk River interfluve

E. Huntsville fauna - Alabama north of Tennessee River, also Elk River and Crow Creek drainages in Tennessee

F. Guntersoille fauna - Alabama between the Tennessee River and the Hartselle escarpment 
fauna. Region I extends northward into southern Indiana along the Mitchell plain and adjacent Norman and Crawford uplands, and region IV extends southwestward through Tennessee into north Alabama. The only other major cave faunal provinces of the Interior Low Plateaus - the Central Basin fauna of Tennessee (V) and the fauna of southern Illinois (VI) - are not represented in Kentucky. Subunits may be proposed for some of these broad faunal regions, particularly regions I and IV, but in the following discussion the faunal picture will be painted with broad strokes except where directly pertinent to the Mammoth Cave system. The impoverished and little-known cave fauna of the Pine Mountain fault block in southeastern Kentucky is here ignored; its affinities appear to lie with the cave faunas of the Appalachian valley rather than with those of the Interior Low Plateaus. Since the regional cave faunas of the United States have never been described or properly characterized, I have attempted to do this in a preliminary fashion in order to set the Mammoth Cave fauna in proper perspective.

(I) The Pennyroyal Plateau (defined here in a more restricted sense than usual among physiographers) is a karst plain developed on Mississippian limestones of the Chester and upper Meramac series. It is bounded to the west by the Dripping Spring escarpment - the topographic expression of the Big Clifty sandstone - and approximately on the east by the contact between the St. Louis limestone and the underlying Salem and Warsaw limestones. It is a southward extension of the Mitchell plain of southern Indiana, and sweeps in a broad arc across the northwest corner of Middle Tennessee and into southwest Kentucky. In northern Kentucky, where the Salem and Harrodsburg limestones are narrowly exposed, the eastern boundary of the Pennyroyal is formed by Muldraugh's Hill, the recessional escarpment at the edge of the Bluegrass. Farther south (e.g.,east of Mammoth Cave) the Salem-Warsaw (usually mapped as a single lithologic unit in this part of Kentucky) is widely preserved in the Cumberland saddle on the northwest flank of the Cincinnati arch, and the sudden change in the nature of the karst topography and in the composition of the cave fauna takes place along a stratigraphic contact rather than along a physiographic escarpment. The Dripping Spring escarpment, behind which lies the narrow Mammoth Cave plateau, is a solutional cuesta, the strata dipping gently toward the Western Kentucky Coal Basin. Caves of the Pennyroyal (restricted sense) are typically rather extensive stream caverns, a few of them 5 to 15 kilometers in length, but gallery segments up to 60 meters above the water table may be locally preserved beneath the sandstone cap of the Mammoth Cave plateau. 
The Pennyroyal cave faunas are characterized by the cavefishes, Amblyopsis spelaea in the north and Typhlichthys subterraneus in the south and west; the blind crayfishes of the genus Orconectes (O.inermis in the north and $O$.pellucidus in the south); amphipods of the genus Stygobromus (except in the north); the carabid beetle Neaphaenops tellkampfii (except in the west); Pseudanophthalmus of the pubescens group (except in the north); and the cave cricket, Hadenoecus subterraneus.

The Pennyroyal fauna exhibits at least 3 major subunits in Kentucky - west (I-E), south (I-D, includes the Mammoth Cave system), and north (I-C). Cave faunas of the Mississippian plateaus of southern Indiana include Amblyopsis spelaea and Orconectes inermis, but not the other species or groups mentioned; at least two subunits can be distinguished (I-B from the Ohio River to and perhaps including the Lost River drainage, and I-A including the Bedford and Bloomington areas), but our primary concern is with the Kentucky Pennyroyal. The fauna of the north Pennyroyal (I-C) typically includes Amblyopsis spelaea, Orconectes inermis, the amphipod Crangonyx packardi, the carabid beetle Pseudanophthalmus barberi Jeannel, the millipede Scoterpes copei, and Hadenoecus. Pseudanophthalmus menetriesii (a northern subspecies), Carychium stygium, and Ptomaphagus hirtus extend northward a short distance into this faunal province, and there are possibly other links with the fauna of the south Pennyroyal. The north Pennyroyal (Breckinridge) fauna occurs in Pennyroyal caves and caves in the upland to the west (Mammoth Cave plateau), south to a prominent ridge across northern Hart County into Green County. This ridge, which is sandstone-capped, represents the stratigraphic and topographic expression of a pre-Pennsylvanian river channel (Burroughs, 1923). It is broken by minor faults, plunges to the west, and rises to the east, where the St. Louis limestone - and the south Pennyroyal fauna - extends into western Green County in the valley of Green River. The Hart County Ridge is thus a partial barrier to troglobite dispersal between regions I-C and I-D.

The south Pennyroyal (Mammoth Cave) fauna (I-D) extends from the south side of the Hart County Ridge southwestward along the Pennyroyal plateau and Mammoth Cave plateau to include the drainage basins of the Green River and its tributary, the Barren River. The watershed between the drainage basins of the Green and Red rivers is a marked barrier to many terrestrial troglobites, but has affected dispersal of aquatic species little or not at all. This apparent paradox may be explained by the following hypothesis. As phreatic subterranean drainage networks extend headward in a karst terrane 
of low gradient and limited relative relief, there is frequent stream piracy between drainages on opposite sides of a watershed (cf. Piper, 1932). This results in shifting of channel segments from one system to the other, and maintains gene flow between aquatic populations inhabiting both networks. Furthermore, seasonal flooding may temporarily fill air spaces between adjacent channels tributary to different networks (as, for example, the waters of Echo and Styx rivers in Mammoth Cave merge during floods) and effect dispersal of aquatic faunas. Air-filled solutional openings above the fluctuating water table, however, rarely communicate across subterranean drainage divides, and are further subject to blockage by siltation, sinkhole slump, dripstone deposition, and fill from surface erosional processes.

The south Pennyroyal (Mammoth Cave) fauna includes Typhlichthys (Amblyopsis occurs south of the Hart County Ridge only in the Mammoth Cave system itself), Orconectes pellucidus, Stygobromus, Pseudanophthalmus menetriesii (s. str.), P. striatus (s. str.), P. pubescens, Neaphaenops, Scoterpes copei (s.str.), and Hadenoecus. In addition there are at least three terrestrial troglobites more or less confined to this region - Carychium stygium, Phalangodes armata, and Ptomaphagus hirtus; these forms have penetrated the Hart County Ridge at a single point, in northwest Hart County, and do not extend farther into region I-C. The Mammoth Cave fauna persists essentially unchanged, except for a few highly local endemics ( Palaemonias ganteri, Batrisodes henroti, Pseudanophthalmus inexpectatus, Pseudanophthalmus audax) in Mammoth Cave itself, along the Pennyroyal from Munfordville to Bowling Green, a distance of approximately 70 kilometers.

The west Pennyroyal (Hopkinsville) fauna (I-E) includes O.pellucidus, Typhtichthys subterraneus, Hadenoecus subterraneus, and Stygobromus, but most of the terrestrial species differ from those of the south Pennyroyal, as previously mentioned. A different species of Scoterpes is present. Carabid beetles (trechines) are represented only by Pseudanophthalmus ciliaris Valentine, P. colemanensis Barr, P. orlindae Barr, and other (undescribed) species of the pubescens group, with a few peripherally distributed species of the cumberlandus group. The west Pennyroyal plateau and its fauna extends from Warren County (approximately) westward to the Ohio River, and also occurs in parts of Sumner, Robertson, Montgomery, and Stewart counties, Tennessee. The same limestone beds continue across the Ohio River into southern Illinois, but unlike the situation between the Mitchell plain and the north Pennyroyal, the Ohio here constitutes a formidable dispersal barrier of long standing, and there is no close affinity between the 
cave faunas of the west Pennyroyal and southern Illinois (region VI; see Barr and Peck, 1966).

(II) The Bluegrass is a physiographic basin developed on a structural dome (Jessamine dome) along the axis of the Cincinnati arch. Limestones of middle Ordovician age are exposed near the center, with Silurian and Devonian rocks on the flanks. The caves are generally small, rarely exceeding 2 kilometers in length (known maximum 5 kilometers), and highly localized in areas of outcrop of the more caverniferous limestones. There is little evidence of widespread troglobite dispersal between cave systems. The principal faunal elements of interest with respect to the Mammoth Cave fauna are (a) a large number of species of Pseudanophthalmus of the inexpectatus species group (the Mammoth Cave species is at the western periphery of the geographic distributions of the species group; (b) at least one endemic species of Stygobromus; (c) the isopod, Asellus stygius; and (d) the occurrence of Hadenoecus subterraneus in an isolated group of small caves near Camp Nelson, Jessamine County, near the center of the dome (this, incidentally, is the type locality for this species of cave cricket). On the whole, there is little suggestion of close affinity between the fauna of the Mammoth Cave system and the caves of the Bluegrass.

(III) The Cumberland Saddle region lies south and east of Mammoth Cave. The Cincinnati arch plunges south of the Jessamine dome, rising again in Middle Tennessee to form the Nashville dome, on which is developed the Central Basin (region V), an area which is structurally and stratigraphically comparable to the Bluegrass. The structural low between the two domes has been termed the Cumberland saddle. On the southwestern flank of the saddle is a merokarstic terrane developed on the Salem-Warsaw limestone and the Fort Payne formation. Numerous caves of moderate to small extent occur in the SalemWarsaw, and in highly local, biohermal reef limestone of the Fort Payne formation, which is - except for the crinoidal reef limestone elsewhere a non-caverniferous chert. Faunal elements in common with the Mammoth Cave fauna include (a) Asellus stygius, (b) Pseudanophthalmus of the menetriesii group ( $P$. striatus plus two different species not found in Mammoth Cave), (c) pseudoscorpions of the genus Kleptochthonius (subgenus Chamberlinochthonius, different species), (d) Scoterpes copei (subsp.), and (e) Batrisodes spp. (Pselaphidae). Conspicuous by their absence are Typhlichthys, Orconectes pellucidus, Phalangodes armata, Neaphaenops, Carychium stygium, Ptomaphagus, and even Hadenoecus. 
The faunal change between the south Pennyroyal and the Cumberland saddle slope is one of the sharpest and most perplexing in the Interior Low Plateaus. The break is so closely tied to the contact between the St. Louis and Warsaw limestones that one looks for an explanation based on different dispersal potential in the two formations. Possibly the massive, relatively pure Ste. Genevieve and St. Louis limestones are honeycombed with solutional openings, facilitating the dispersal of troglobites, but dispersal potential through SalemWarsaw terranes is reduced and erratic because of thin bedding and incorporation of considerable silt and limy shale into the latter. This hypothesis is not wholly satisfactory but is quite probably at least a partial explanation for the observed troglobitic distribution in the region. The sharp break in troglobite distribution across the St. LouisWarsaw contact is analogous to the faunal break observed by A. R. Wallace ("Wallace's Line") in the East Indies, but apparently has a decidedly different explanation.

(IV) The Cumberland Plateau faunal region lies along the western margin of the Cumberland plateau in eastern Kentucky, running southwestward through Tennessee into northern Alabama, where it turns westward north of the Hartselle escarpment. Caves occur in Mississippian limestones of the Chester and Meramac series, as in the Pennyroyal. A broad karst plain similar to the Pennyroyal lies west of the plateau front in southeastern Kentucky, extending into Tennessee and north Alabama as the Eastern Highland Rim. In northeast Kentucky the karst plain disappears and the Bluegrass abruptly confronts the sandstone-capped outliers of the margin of the plateau; the caverniferous limestone also thins to the north and caves are fewer, smaller, and more locally developed. The fauna of this northern part of the plateau in Kentucky is more closely related to the cave fauna of the Bluegrass than to that of any other region. In southeastern Kentucky, Tennessee, and north Alabama, however, there are numerous caves, many of them unusually extensive ( 15 to 25 kilometers), and a much richer troglobitic fauna has evolved, showing at least remote (generic) affinity with the Mammoth Cave fauna. The origin and evolution of the cave fauna of the Cumberland plateau is one of the most challenging and complex problems in North American biospeleology. In the present paper I can only present a brief sketch of the fauna and its apparent affinities with that of Mammoth Cave.

One might expect a close relationship between the south Pennyroyal fauna and the Cumberland plateau fauna of southeast Kentucky, since the two areas are about 125 kilometers apart, have similar stratigraphy, and both exhibit extensive cavern development. Such is not 
the case. The trechine beetles of the south Kentucky Cumberland plateau include Darlingtonea kentuckensis Valentine, Nelsonites jonesei Val., Ameroduvalius jeanneli Val., Trechus cumberlandus Barr (a troglophile), and various Pseudanophthalmus spp. of the intermedius and cumberlandus groups. Other prominent members of the cave communities of the region are millipedes, Scoterpes sp. and Pseudotremia sp.; Rhagidia cavernarum; collembolans, Pseudosinella hirsuta (DelamareDéboutteville) and $P$. christianseni Salmon; Orconectes australis packardi Rhoades; Kleptochthonius spp.; Asellus stygius; Crangonyx packardi; and Hadenoecus subterraneus. Although the fauna is potentially as rich in troglobites as that of the Mammoth Cave region, there are few direct links between the two areas. The few troglobitic species in common - Rhagidia cavernarum, Asellus stygius, and so forth - are apparently distributed across the intervening Cumberland saddle slope. Typhlichthys subterraneus is apparently absent in southeast Kentucky, but appears again in the Cumberland plateau of Tennessee, and is linked with the south Pennyroyal by scattered populations of the Central Basin in between. Phalangodes armata has been reported from the Cumberland plateau from Tennessee to north Alabama (Goodnight and Goodnight, 1960), but there are no intermediate records, and the Cumberland plateau populations possibly represent an allopatric sibling species. In the Tennessee portion of the Cumberland plateau all the species of trechine beetles are different from those of the Kentucky portion, and the species of Scoterpes, Pseudotremia, Kleptochthonius, and even Hadenoecus are changed.

The north Alabama segment of the Cumberland plateau is a bit more distinctive; it lies within the drainage basin of the Tennessee River. Genera in common with the Mammoth Cave fauna include Sphalloplana, Asellus, Glyphyalinia, Stygobromus, Orconectes, Palaemonias, Kleptochthonius, Phanetta, Scoterpes, Plusiocampa, Hadenoecus, Pseudanophthalmus, Ptomaphagus, and Batrisodes. Some wide-ranging species in common include Helicodiscus hadenoecus, Sagittocythere barri, Stygobromus exilis, Phanetta subterranea, and Typhlichthys subterraneus. A number of elements peculiar to the north Alabama region enter into the faunal assemblage in its caves, but the general resemblance to the fauna of the Mammoth Cave region is somewhat closer than between Mammoth Cave and the fauna of the intervening Central Basin.

(V) The Central Basin of Tennessee shows a general regional similarity to both the Pennyroyal and north Alabama in its cave faunas, but seldom is the fauna of any given cave system as rich as in the Cumberland plateau or the Pennyroyal. Forms present include Sphal- 
loplana, Speophila, Helicodiscus hadenoecus, Sagittocythere barri, Asellus alabamensis Stafford, Stygobromus vitreus and S. exilis, Kleptochthonius, Pseudozaona, Anthrobia monmouthia, Phanetta subterranea, Rhagidia, Scoterpes, Plusiocampa, Hadenoecus, Pseudanophthalmus (chiefly of the cumberlandus group), Ptomaphagus, Typhlichthys, and (in the northeast only) Orconectes australis packardi. Caves are somewhat larger and more numerous than in the Bluegrass, a region of comparable structure and stratigraphy.

Two zoogeographic puzzles require mention here. There are two elements inexplicably absent in the Mammoth Cave fauna, although both are present in the Pennyroyal to the north and southwest as well as in the caves of the Cumberland saddle slope. One element is the millipede genus Pseudotremia, which has a very large number of troglobitic and troglophilic species in caves of the Interior Low Plateaus, with the curious exception of the Mammoth Cave region. The other absent element is the widespread troglobitic collembolan Pseudosinella hirsuta, the distribution of which includes caves near Bowling Green, Edmonton, Greensburg, and Elizabethtown, but swings eastward in a broad arc around the Mammoth Cave region. Why this should be so is not at all clear. Indeed, the paucity of troglobitic collembolans (no Sinella or Pseudosinella) from the Mammoth Cave community is a situation without parallel elsewhere in the Interior Low Plateaus.

In accord with the prevailing view on origin of North American troglobites (Jeannel, 1943, 1949; Vandel, 1964; Barr, 1965 and in press), we can assume that the troglobitic fauna of the Mammoth Cave system evolved from epigean ancestors living in the vicinity of the caves, first as non-cavernicoles, then as troglophiles. Extinction of surface populations of the troglophile species - the result of widespread climatic or other environmental changes associated with alternating cold-wet and warm-dry periods - effected isolation of ancestral troglophile populations in the caves. The ancestors of cave trechine beetles, for example, probably lived in wet talus piles or moss carpets in conifer forests which covered much of Kentucky during glacial maxima. Following retreat of the glaciers, the onset of a warming, drying trend progressively restricted the ancestral species to cold, wet microhabitats in shaded ravines, sinkholes, and the mouths of caves. At this stage they probably became troglophiles. Continued warming and drying led to extinction of the remaining surface populations, and under the ensuing conditions of spatial isolation the cave populations were free to adapt more precisely to the cave environment, and undergo a reconstruction of the epigenotype of their species. Many of the caveassociated regressive evolutionary processes (notably loss of eyes and 


\section{Table 2}

Analysis of Troglobitic Fauna of the Mammoth Cave System

A. Species probably originating in the Mammoth Cave faunal region (I-D)

( \# = System-limited)

Sphalloplana percaeca?

Speophila buchanani?

\# Helicodiscus punctatellus?

\# Sagittocythere stygia

Orconectes pellucidus

\# Palaemonias ganteri

\# Kleptochthonius hageni

\# Kleptochthonius cerberus

Phalangodes armata

\# Anthrobia monmouthia (local form)

Scoterpes copei

\# Antriadesmus fragilis

Linopodes mammouthia?

\# Arrhopalites altus

Plusiocampa cookei

\# Dorypteryx hageni

Neaphaenops tellkampfii

Pseudanophthalmus menetriesii

\# Pseudanophthalmus audax

\# Pseudanophthalmus inexpectatus

\# Batrisodes henroti

Ptomaphagus hirtus

B. Species probably originating outside the Mammoth Cave faunal region, with dispersal route

Antroselates spiralis - north Pennyroyal

Helicodiscus hadenoecus - south Pennyroyal

Cyclops donnaldsoni - north Pennyroyal? / ?Cumberland saddle

Attheyella pilosa - north Pennyroyal? / ?Cumberland saddle

Sagittocythere barri - south Pennyroyal

Candona sp. - ?

Asellus stygius - north or south Pennyroyal

Crangonyx packardi - north Pennyroyal? / ? Cumberland saddle

Stygobromus vitreus - south Pennyroyal

Stygobromus exilis - south Pennyroyal

Pseudozaona mirabilis - Cumberland saddle? / ? south Pennyroyal

Phanetta subterranea -?

Porrhomma casernicolum -?

Bathyphantes weyeri-?

Rhagidia cavernarum - Cumberland saddle

Pseudanophthalmus striatus - Cumberland saddle

Pseudanophthalmus pubescens - south Pennyroyal

Amblyopsis spelaea - north Pennyroyal

Typhlichthys subterraneus - south Pennyroyal 
melanin pigments) probably accompanied this genetic reconstruction as selectively neutral byproducts of adaptation. Other major climatic and environmental changes of the Pleistocene may have been instrumental in isolating aquatic ancestors in caves; these include temperature and rainfall variations as well as a marked change in stream gradients when regional uplift at the beginning of the Pleistocene transformed sluggish, meandering streams of low gradient into rapidly flowing, rejuvenated drainage systems.

An analysis of the 40-odd species of troglobites known from the Mammoth Cave system (Table 2) shows that a little more than half probably originated either in the cave itself or in nearby caves of the south Pennyroyal. The remainder of the species have distributions which suggest that they originated elsewhere and colonized the Mammoth Cave system via subterranean dispersal routes. The exact dispersal corridor for any given species is often debatable, but enough information is available to show that the troglobite community of Mammoth Cave has evolved - probably throughout the Pleistocene development of the cave itself - through faunal increments from 4 sources: (1) troglobite speciation in situ in the southern Pennyroyal caves; (2) dispersal along a north Pennyroyal corridor; (3) dispersal along a south Pennyroyal corridor; and (4) dispersal across a Cumberland saddle corridor. Just as its special geologic situation has assured the development of an extraordinarily extensive cavern system, Mammoth Cave's geographic location at the "crossroads" of three major "highways" of subterranean dispersal has contributed to the development of its exceptionally rich and varied troglobitic fauna.

\section{SUMMARY}

The Mammoth Cave system includes more than 175 kilometers of explored passages in Mammoth Cave National Park, Kentucky. Although biologists have explored the caves intermittently since 1822, the inventory of living organisms in the system is still incomplete. The present study lists approximately 200 species of animals, 67 species of algae, 27 species of fungi, and 7 species of twilight-zone bryophytes. The fauna is composed of $22 \%$ troglobites, $36 \%$ troglophiles, $22 \%$ trogloxenes, and $20 \%$ accidentals, and includes protozoans, sponges, triclads, nematodes, nematomorphs, rotifers, oligochaetes, gastropods, cladocerans, copepods, ostracods, isopods, amphipods, decapods, pseudoscorpions, opilionids, spiders, mites and ticks, tardigrades, millipedes, centipedes, collembolans, diplurans, thysanurans, cave crickets, hemipterans, psocids, moths, flies, fleas, beetles, fishes, amphibians, birds, and mammals. The Mammoth Cave community has evolved throughout the Pleistocene concomitantly with development of the cave system. The troglobitic fauna is derived from 4 sources: (1) troglobite speciation in 
situ in the system itself; (2) dispersal along a north Pennyroyal plateau corridor; (3) dispersal along a south Pennyroyal plateau corridor; and (4) dispersal across the southwest slope of the Cumberland saddle merokarst.

\section{RÉSUMÉ}

Le système de la Mammoth-Cave comporte plus de 175 kilomètres de galeries souterraines explorées dans le Parc National Mammoth-Cave (Kentucky). Etant donné que les biologistes n'avaient exploré ces grottes que de temps en temps depuis 1822, l'inventaire des organismes vivants dans le système était resté encore incomplet. A la suite de la présente étude, on enregistre approximativement 200 espèces d'animaux, 67 espèces d'Algues, 27 espèces de Champignons et 7 espèces de Bryophytes de la zone éclairée. La faune, renfermant $22 \%$ de troglobies, $36 \%$ de troglophiles, $22 \%$ de trogloxènes réguliers et $20 \%$ de trogloxènes accidentels, comporte Protozoaires, Eponges, Triclades, Nématodes, Nématomorphes, Rotifères, Oligochètes, Gastéropodes, Cladocères, Copépodes, Ostracodes, Isopodes, Amphipodes, Décapodes, Pseudoscorpions, Opilionides, Araignées, Acariens, Tardigrades, Diplopodes, Chilopodes, Collemboles, Diploures, Thysanoures, Orthoptères, Hémiptères, Psocoptères, Lépidoptères, Diptères, Siphonaptères, Coléoptères, Poissons, Amphibiens, Oiseaux et Mammifères. La biocénose de la Mammoth-Cave a évolué pendant tout le pleistocène au fur et à mesure de la genèse du système des grottes lui-même. La faune troglobie pourrait avoir 4 origines: (1) spéciation troglobienne autochtone dans le système; (2) dispersion le long d'un corridor Nord du Plateau-Pennyroyal; (3) dispersion le long d'un corridor Sud du Plateau-Pennyroyal; et (4) dispersion à travers la pente Sud-Ouest de la selle mérokarstique du Cumberland.

\section{REFERENCES}

Agassiz, Louis (1851) - Observations of the blind fish of the Mammoth Cave. American Jour. Sci., ser. 2, 11: 127-128.

- (1853) - Recent researches of Prof. Agassiz. Ibid., 16: 134.

Bailey, Vernon (1933) - Cave life of Kentucky, mainly in the Mammoth Cave region. American Midl. Nat., 14: 385-635.

Banks, Nathan (1895) - Notes on the Pseudoscorpionida. Jour. New York Entomol. Soc., 3: 1-13.

Barr, Thomas, C., Jr. (1955) - Biological Report, pp. 280-283. In: Joe Lawrence, Jr., and Roger W. Brucker: The Caves Beyond. New York: Funk and Wagnalls.

- (1959a) - The male of Pseudanophthalmus audax (Coleoptera, Carabidae). Trans. Kentucky Acad. Sci., 20:1-3.

- $(1959 \mathrm{~b})$ - New cave beetles (Carabidae, Trechini) from Tennessee and Kentucky. Jour. Tennessee Acad. Sci., 34: 5-30.

- (1962) - The blind beetles of Mammoth Cave, Kentucky, American. Midl. Nat., 68: 278-284. 
- (1963) - Studies on the cavernicole Ptomaphagus of the United States (Coleoptera, Catopidae). Psyche, 70: 50-58.

- (1964a) - Cave ecology (meeting report). Science, 144 (No. 3616): 321 $322+$ cover photograph.

- $(1964 b)$ - Non-troglobitic Carabidae (Coleoptera) from caves in the United States. Coleopt. Bull., 18: 1-4.

- (1965) - The Pseudanophthalmus of the Appalachian valley (Coleoptera, Carabidae). American Midl. Nat., 73: 41-72.

- (1966) - Evolution of cave biology in the United States, 1822-1965. Nat. Speleol. Soc. Bull., 28: 15-21.

- (1967) - Cave Carabidae (Coleoptera) of Mammoth Cave. Psyche, 73: 284-287; 74: 24-26.

- (In press) - Cave ecology and the evolution of troglobites. Evolutionary Biology, vol. 2. New York: Appleton-Century Crofts.

Barr, Thomas C., Jr., and Kuehne, Robert A. (1962) - The cavefish, Amblyopsis spelaea, in northern Kentucky. Copeia, 1962, no. 3: 662.

Barr, Thomas C., Jr., and Peck, Stewart B. (1966) - Discovery of Pseudanophthalmus in southern Illinois (Coleoptera: Carabidae). American Midl. Nat., 76: 519-522.

Barr, Thomas C., Jr., and Reddell, James R. (1967) - The arthropod cave fauna of the Carlsbad Caverns region, New Mexico. Southwestern Naturalist, 12 (3): - - -.

Berland, Lucien (1931) - Arachnides aranéides (Biospeologica LVI.) Arch. zool. exp. et gén., $71: 383-388$.

Bolívar Y Pieltain, Candido, and Jeannel, René (1931) - Campagne spéologique dans l'Amérique du Nord en 1928 (première série) (Biospeologica LVI). Ibid., 71 : 293-316.

Brashear, David, Wiseman, Ralph, and Barr, Thomas C., Jr. (1967) A psychrophilic yeast from Mammoth Cave, Kentucky. Int. Jour. Speleol., 2: 403-404.

Bretz, J. Harlen (1942) - Vadose and phreatic features of limestone caverns. Jour. Geol., 50:675-811.

Brown, Frank A. (1961) - Diurnal rhythm in cave crayfish. Nature, 191: 929-930.

Brucker, Roger W. (1966) - Truncated cave passages and terminal breakdown in the central Kentucky karst. Nat. Speleol. Soc. Bull., 28: 171-178.

Buchanan, J. William (1936) - Notes on an American cave flatworm, Sphalloplana percaeca (Packard). Ecology, 17: 194-241.

Burroughs, W. G. (1923) - A Pottsville-filled channel in the Mississippian. Kentucky Geol. Surv., ser. 6, vol. 10: 115-126.

Gall, Richard Ellsworth (1897) - Some notes on the flora and fauna of Mammoth Cave, Kentucky. American Nat., 31 : 377-392.

Caumartin, Victor (1957) - Recherches sur une bactérie des argiles des cavernes et des sédiments ferrugineux. Compt. Rend. Acad. Sci., Paris, 245: 1758-1760.

Ghappuis, P. A. (1931) - Grustacés copépodes (Biospeologica LVI). Arch. zool. exp. et gén., 71 : 345-360.

Chopard, L. (1931) - Insectes orthoptères (Biospeologica LVI). Arch. zool. exp. et gén., $71: 389-402$. 
Christiansen, Kenneth A. (1960a) - The genus Pseudosinella (Collembola, Entomobryidae) in caves of the United States. Psyche, 67:1-25.

- $(1960 \mathrm{~b})$ - A preliminary survey of the knowledge of North American cave Collembola. American Midl. Nat., 64: 39-44.

- $(1960 \mathrm{c})$ - The genus Sinella Brook (Collembola, Entomobryidae) in Nearctic caves. Ann. Entomol. Soc. America, 53: 481-491.

- (1964) - A revision of the Nearctic members of the genus Tomocerus (Collembola, Entomobryidae). Rev. Ecol. Biol. Sol, 1: 639-678.

- (1966) - The genus Arrhopalites (Collembola, Sminthuridae) in the United States and Canada. Int. Jour. Speleol., 2: 43-73, pl. 11-19.

Condé, Bruno (1949) - Campodéidés cavernicoles de la région des Appalaches. Notes Biospéol., 4: 125-139.

Cope, Edward Drinker (1872) - On the Wyandotte Cave and its fauna. American Nat., 6: 406-422.

Davidson, Robert (1840) - An excursion to the Mammoth Cave and the Barrens of Kentucky, with some notices of the early settlement of the State. Lexington: A. T. Skillman \& Son. 148 pp.

Davis, William Morrison (1930) - Origin of limestone caverns. Geol. Soc. America Bull., 41 : 475-628.

Dearolf, Kenneth (1942) - Report of a biological reconnaissance of the New Discovery in Mammoth Cave, Kentucky, January 7-11, 1941. Nat. Speleol. Soc. Bull., 4: 48-52.

De Beauchamp, P. (1931) - Turbellariés triclades (Biospeologica LVI). Arch. zool. exp. et gén., 71: 317-331.

De Kay, James E. (1842) - (Description of Amblyopsis spelaeus.) Footnote p. 187, Zoology of New York, or the New York Fauna. Part IV. Fishes. Albany, 1842.

Eigenmann, Carl H. (1899) - Explorations in the caves of Missouri and Kentucky. Proc. Indiana Acad. Sci., 8: 58-61.

- (1905) - Divergence and convergence in fishes. Biol. Bull., 8: 59-66.

- (1909) - Cave vertebrates of America: a study in degenerative evolution. Carnegie Inst. Washington, Publ. 104, $241 \mathrm{pp}$.

Emerton, J. H. (1875) - Notes on spiders from caves in Kentucky and Indiana. American Nat., 9: 278-281.

Fage, Louis (1931) - Crustacés amphipodes et décapodes (Biospeologica LVI). Arch. zool. exp. et gén.,71:361-374.

Faust, Burton S. (1949) - The formation of saltpeter in caves. Nat. Speleol. Soc. Bull., 11: 17-23.

Fox, Irving (1940) - Fleas of eastern North America. Ames: Iowa State College Press, $191 \mathrm{pp}$.

Gardner, J. H. (1935) - Origin and development of limestone caverns. Geol. Soc. America Bull., 46: 1255 - 1274.

Garman, Harrison (1924) - A little-known cave crayfish. Trans. Kentucky Acad. Sci., 1: 87-94.

Gates, G. E. (1959) - Earthworms of North American caves. Nat. Speleol. Soc. Bull., 21 : 77-84.

Ginet, René, and Rodolphe Puglisi (1964) - Écologie de Fonticola notadena de Beauchamp (Turbellarié, Triclade) dans la grotte de la Balme (Isère, France) survie en période de sécheresse. Int. Jour. Speleol., 1 : 203-216. 
Girard, Charles F. (1860) - Ichthyological notices. Proc. Acad. Nat. Sci., Philadelphia, 1859 (1860): 56-68.

Goodnight, Glarence J., and Marie L. Goodnight (1960) - Speciation among cave opilionids of the United States. American Midl. Nat., 64: $34-38$.

Goodrich, Galvin (1940) - The Pleuroceridae of the Ohio River drainage system. Occ. Pap. Mus. Zool., Univ. Michigan, no. 417, 21 pp.

Hagen, Hermann H. (1870) - Monograph of the North American Astacidae. Mem. Mus. Comp. Zool., Harvard Univ., vol. 2.

- (1872) - The blind crayfish. American Nat., 6: 494.

HaHN, W. L. (1908) - Notes on the mammals and cold-blooded vertebrates of the Indiana University farm, Mitchell, Indiana. Proc. United States Nat. Mus., 35: 545-581.

Hall, Jонn S. (1961) - Myotis austroriparius in central Kentucky. Jour. Mammal., 42: 399-400.

- (1962) - A life history and taxonomic study of the Indiana bat, Myotis sodalis. Reading (Pennsylvania) Publ. Mus. \& Art Gall., Sci. Publ., no. $12,68 \mathrm{pp}$.

- (1963) - Notes on Plecotus rafinesquii in central Kentucky. Jour. Mammal., 44: 119-120.

Hart, C. W., Jr., and Hart, Dabney G. (1966) - Four new entocytherid ostracods from Kentucky, with notes on the troglobitic Sagittocythere barri. Notulae Nat. (Acad. Nat. Sci., Philadelphia), no. 388, 10 pp.

Hart, C. W., Jr., and Hоввs, Horтол H., Jr. (1961) - Eight new troglobitic ostracods of the genus Entocythere (Crustacea, Ostracoda) from the eastern United States. Proc. Acad. Nat. Sci., Philadelphia, 113: $173-185$.

Hatch, Melville H. (1933) - Studies on the Leptodiridae (Catopidae) with descriptions of new species. Jour. New York Entomol. Soc., 41: 187-239.

Hay, William Perry (1903) - Observations on the crustacean fauna of the region about the Mammoth Cave, Kentucky. Proc. United States Nat. Mus., 25: 223-236.

Hobbs, Horton H., Jr., and Barr, Thomas C. Jr., (1960) - The origins and affinities of the troglobitic crayfishes of North America (Decapoda, Astacidae). I. The genus Cambarus. American Midl. Nat., 64: 12-33.

Holsinger, JoHn R. (1965) - Redescriptions of two poorly known species of cavernicolous rhagidiid mites (Acarina, Trombidiformes) from Virginia and Kentucky. Acarologia, 7: 654-662.

Horn, George H. (1868) - Catalogue of Coleoptera from south-west Virginia. Trans. American Entomol. Soc., 2: 123-128.

- (1883) - Miscellaneous notes and short studies of North American Coleoptera. Ibid., 10: 269-293.

Hubbard, H. G. (1880) - Two days' collecting in the Mammoth Cave, with contributions to a study of its fauna. American Entomol., 3: 34-40, 79-86, figs. 8-10, 19-24.

Hubbell, Theodore H. (1936) - A monographic revision of the genus Ceuthophilus (Orthoptera, Gryllacrididae, Rhaphidophorinae). Univ. Florida Publ., Biol. Sci. Ser., 2 (1), 551 pp. + 38 pl. 
Hubricht, Leslie (1943) - Studies on the Nearctic freshwater Amphipoda, III. Notes on the freshwater Amphipoda of eastern United States, with description of ten new species. American Midl. Nat., 29:683-712.

- (1960) - The cave snail, Carychium stygium Call. Trans. Kentucky Acad. Sci., 21: 35-38.

- (1962) - New species of Helicodiscus from the eastern United States. Nautilus, 75: 102-107, pl. 7-9.

- (1963) - New species of Hydrobiidae. Ibid., 76: 138-140, pl. 8.

- (1964) - Land snails from the caves of Kentucky, Tennessee, and Alabama. Nat. Speleol. Soc. Bull., 26: 33-36.

- (1965) - Four new land snails from the southeastern United States. Nautilus, 79:4-7, pl. 2.

Hyman, Libie H. (1937) - Studies on the morphology, taxonomy, and distribution of North American triclad Turbellaria. VIII. Some cave planarians of the United States. Trans. American Micr. Soc., 56: 457477.

Jeannel, René (1920) - Notes sur les Trechini. Bull. Soc. Entomol. France, 1920: 150-155.

- (1928) - Monographie des Trechinae, $3^{\mathbf{e}}$ livraison. L'Abeille, 35: 1-808.

- (1931) - Révision des Trechinae de l'Amérique du nord. Arch. zool. exp. et gén., 71: 403-499.

- (1943) - Les fossiles vivants des cavernes. Paris: Gallimard. 321 pp.

- (1949) - Les coléoptères cavernicoles de la région des Appalaches. III. Étude systématique. Notes Biospéol., 4: 37-104.

Jeannel, René, and Henrot, Henri (1949) - Les coléoptères cavernicoles de la région des Appalaches. I. La région des Appalaches (Jeannel), and II. Enumération des grottes explorées (Henrot). Ibid., 4: 11-36.

Jegla, Thomas C., and Hall, John S. (1962) - A Pleistocene deposit of the free-tailed bat in Mammoth Cave, Kentucky, Jour. Mammal., 43: 477-481.

Jillson, Willard Rouse (1923) - Land of ten thousand sinks. Science, $58: 184$.

Jones, H. J. (1965) - Algological investigations in Mammoth Cave, Kentucky. Int. Jour. Speleol., 1: 491-516.

Keyserling, Eugen Graf (1881) - Neue Spinnen aus Amerika, III. Verh. zool.-bot. Ges. Wien, 31: 269-314, pl. 11.

KliE, W. (1931) - Crustacés ostracodes (Biospeologica LVI). Arch. zool. exp. et gén., 71: 333-344.

Koford, C. A. (1899) - The plankton of Echo River, Mammoth Gave. Trans. American Micr. Soc., 21 : 113-126.

Kuehne, Robert A. (1966) - Depauperate fish faunas of sinking creeks near Mammoth Cave, Kentucky. Copeia, 1966: 306-311.

Lobecк, Armin Kohl (1929) - The geology and physiography of the Mammoth Cave National Park. Kentucky Geol. Surv., ser. 6, no. 31: 327299.

Loomis, H. F. (1943) - New cave and epigean millipedes of the United States, with notes on some established species. Bull. Mus. Comp. Zool., Harvard Univ., 92: 373-410. 
MAHeU, JAGQUes (1926a) - La flore cavernicole américaine (Grottes de Mammoth-cave et de City-cave, état de Kentucky). Bull. Soc. Bot. France, 73: 39-57.

- (1926b) - La mycologie obscuricole souterraine américaine (Cavernes de City-cave, État de Kentucky, États-Unis). Bull. Trimestr. Soc. Mycol. France, 42: 130-138.

Malcolm, David R., and Chamberlin, Joseph G. (1961) - The pseudoscorpion genus Kleptochthonius Chamberlin (Chelonethida, Chthoniidae). American Mus. Nov., no. 2063, 35 pp.

von Motschulsky, T. Vigtor (1854) - Études entomologiques, 3 e année. Helsingfors, $69 \mathrm{pp}$.

- (1862) - Études entomologiques, $11^{\mathrm{e}}$ année. Dresden, 55 pp.

Mughmore, William B. (1963) - Redescription of some cavernicolous pseudoscorpions (Arachnida, Chelonethida) in the collection of the Museum of Comparative Zoology. Breviora (Mus. Comp. Zool., Harvard), no. 188, $16 \mathrm{pp}$.

- (1964) - New terrestrial isopods of the genus Miktoniscus from eastern United States (Crustacea, Isopoda, Oniscoidea). Ohio Jour. Sci., 64: 51-57.

- (1965) - North American pseudoscorpions of the genus Kleptochthonius, subgenus Chamberlinochthonius (Chelonethida, Chthoniidae). American Mus. Nov., no. 2234, 27 pp.

NAGY, J. P. (1965) - Preliminary note on the algae of Crystal Cave, Kentucky. Int. Jour. Speleol., 1: 479-490.

Pagkard, Alpheus Spring, Jr. (1871) - On the crustaceans and insects of the Mammoth Cave. American Nat., 5: 744-761.

- (1874a) - Occurrence of Japyx in the United States. Ibid., 8: 501-502.

- (1874b) - Larvae of Anophthalmus and Adelops. Ibid., 8: 562-563.

- (1875a) - The invertebrate cave fauna of Kentucky and adjoining States, Araneina. Ibid., 9: 274-278.

- (1875b) - Cave-inhabiting spiders. Ibid., 9:663-664.

- (1876) - The cave-beetles of Kentucky. Ibid., 10: 282-287.

- (1885) - On the structure of the brain of Asellus and the eyeless form Caecidotea. Ibid., 19: 85-86.

- (1888) - The cave fauna of North America, with remarks on the anatomy of the brain and origin of the blind species. Mem. Nat. Acad. Sci. (U.S.A.), 4: pp. 1-156 (1886).

Park, Orlando (1939) - Key to the more common adult animals of Mammoth and adjacent caves, pp. 118-124. In: Orlando Park, W. C. Allee, and V. E. Shelford: A laboratory introduction to animal ecology and taxonomy. Univ. Chicago Press. 257 pp.

- (1956) - New or little-known species of pselaphid beetles from southeastern United States. Jour. Tennessee Acad. Sci., 31 : 54-100.

- (1958) - New or little-known species of pselaphid beetles, chiefly from southeastern United States. Ibid., 33: 39-74.

- (1960) - Cavernicolous pselaphid beetles of the United States. American Midl. Nat., 64: 66-104.

Park, Orlando, and Barr, T. C., Jr. (1961) - Some observations on a cave cricket (Abstr.). Entomol. Soc. America Bull., 7: 144. 
Park, Orlando, Roberts, T.W., and Harris, S. J. (1941) - Preliminary analysis of activity of the cave crayfish, Cambarus pellucidus. American Nat., 75: 154-171.

Piper, Arthur M. (1932) - Ground water in north-central Tennessee. United States Geol. Surv. Water-supply Pap. 640, 238 pp., 4 pl.

Poнl, Erwin R. (1955) - Vertical shafts in limestone caves. Nat. Speleol. Soc. Occ. Pap., no. 2: 1-24.

Pohl, Erwin R., and White, William B. (1965) - Sulfate minerals: their origin in the central Kentucky karst. American Mineral., 50: 1461-
1465 .

Poulson, Thomas L. (1963) - Cave adaptation in amblyopsid fishes. American Midl. Nat., 70: 257-290.

- (1964) - Animals in aquatic environments: animals in caves. In: D. B. Dill. Ed. Handbook of physiology, sect. 4, "Adaptation to the Environment," ch. 47: pp. 749-771. Washington: American Physiol. Soc.

Putnam, F. W. (1872) - The blind-fishes of the Mammoth Cave and their allies. American Nat., 6: 6-30.

- (1875) - On some of the habits of the blind crawfish, Cambarus pellucidus, and the reproduction of lost parts. Proc. Boston Soc. Nat. Hist., 18: 16-19.

Rafinesque, Constantin S. (1832) - The caves of Kentucky. Atlantic Jour., 1 (9) : 27-30.

Reighle, David E., Palmer, John D., and Park, Orlando (1965) Persistent rhythmic locomotor activity in the cave cricket, Hadenoecus subterraneus, and its ecological significance. American Midl. Nat., $74: 57-66$.

Rhoades, Rendell (1944) - The crayfishes of Kentucky, with notes on variation, distribution, and descriptions of new species and subspecies. Ibid., 31: 111-149, 10 figs., 10 maps.

Rosen, Donn Eric (1962) - Comments on the relationships of the North American cave fishes of the family Amblyopsidae. American Mus. Nov., no. 2109, 35 pp.

Shaler, Nathaniel Southgate (1875) - On the antiquity of the caverns and cavern life of the Ohio valley. Mem. Boston Soc. Nat. Hist., 2: 355-363.

Silvestri, F. (1934) - Campodeidae (Biospeologica LVI). Arch. zool. exp. et gén., 76: 379-383. - (1947) - On some Tapygidae in the Museum of Comparative Zoology.
Psyche 54: 209-229.

Smalley, Alfred E. (1961) - A new cave shrimp from southeastern United States (Decapoda, Atyidae). Crustaceana, 3: 127-130.

Swinnerton, A. G. (1932) - Origin of limestone caverns. Geol. Soc. America Bull., 43: 663-694.

TAYlor, DWight W. (1966) - A remarkable snail fauna from Coahuila, Mexico. Veliger, 9: 152-228.

Tellkamp, Theodor G. (1844a) - Beschreibung einiger neuer in der Mammuth-Höhle in Kentucky aufgefundener Gattungen von Gliederthieren. Arch. f. Naturg., 10:318-322, pl. 7.

- (1844b) - Über den blinden Fisch der Mammuth-Höhle in Kentucky, mit Bemerkungen über einige andere in dieser Höhle lebenden Thiere. Müllers Arch. f. Anat. u. Physiol., 4: 384-394, pl. 9. 
Tellkampe, Theodor G. (1845) - Memoirs on the blind fishes and some other animals living in Mammoth Cave in Kentucky. New York Jour. Med., 1845, pp. 84-93.

Thaxter, Roland (1895) - Contribution toward a monograph of the Laboulbeniaceae, Part 1. Mem. American Acad. Arts \& Sci., 12:195-429.

Thоmpson, William (1844) - Notice of the blindfish, crayfish, and insects from Mammoth Cave, Kentucky. Ann. Mag. Nat. Hist., 13: 3.

VAlentine, J. Manson (1931) - New cavernicole Carabidae of the subfamily Trechinae Jeannel. Jour. Elisha Mitchell Sci. Soc., 46: 247-258.

- (1932) - A classification of the genus Pseudanophthalmus Jeannel (fam. Carabidae) with descriptions of new species and notes on distribution. Ibid., 48: 261-280.

VANDEL, A. (1964) - Biospéologie: la biologie des animaux cavernicoles. Paris: Gauthier-Villars. $619 \mathrm{pp}$.

- (1965) - Les Trichoniscidae cavernicoles (Isopoda Terrestria, Crustacea) de l'Amérique du Nord. Ann. Spéléol., 20: 347-389.

Vanlandingham, Sam L. (1965) - Diatoms from Mammoth Cave, Kentucky. Int. Jour. Speleol., 1: 517-539.

- (1966) - Three new species of Cymbella from Mammoth Cave, Kentucky. Ibid., 2 : 133-136.

Viтzтнum, H. (1925) - Die unterirdische Acarofauna, Z. Naturw., 62:125186.

Watson, R. A. (1966) - Central Kentucky karst hydrology. Nat. Speleol. Soc. Bull., 28: 159-166.

Weller, James Marvin (1927) - The geology of Edmonson County. Kentucky Geol. Surv., ser. 6, vol. 28:1-246.

Wolfe, Douglas A., and Cornwell, David G. (1964) - Carotenoids of cavernicolous crayfish. Science, 144 (no. 3625) : 1467-1469.

Woods, Loren P., and Inger, Robert F. (1957) - The cave, spring, and swamp fishes of the family Amblyopsidae of central and eastern United States. American Midl. Nat., 58: 232-256.

Wyman, JefFeries (1843) - Description of a "Blind Fish," from a cave in Kentucky. American Jour. Sci. \& Arts, 45: 94.

- (1850) - On the blind fish of the Mammoth Cave. Proc. Boston Soc. Nat. Hist., 3: 349-357.

- (1853) - On the eye and the organ of hearing in the blind fish (Amblyopsis spelaeus DeKay) of Mammoth Cave. American Jour. Sci.\& Arts, 17: 258-261.

\section{EXPLANATION OF PLATES 37 (1)-64 (28)}

Fig. 1: Location of major cave areas of the Appalachians, Allegheny Plateau, and Interior Low Plateaus.

Fig. 2: Cave regions of Kentucky; compare Table 1.

Fig. 3: Diagrammatic representation of physiography and cavern development at Mammoth Cave. Angle of dip exaggerated approximately $\times 10$. 
Fig. 4: (A) Historic section of Mammoth Cave; modified from M. Kaemper map of 1908. (B) Skeleton map of principal tourist sections in Mammoth Cave; modified from National Park Service map. 1. Historic Entrance. 2. Mammoth Dome. 3. Dead Sea. 4. Echo River. 5. Mary's Vineyard. 6. Marion Avenue. 7. Carmichael Entrance (artificial). 8. Grand Canyon. 9. New Entrance (artificial). 10. Crystal Lake. 11. Radio Room. 12. Frozen Niagara Entrance (artificial).

Fig. 5: Historic Entrance to Mammoth Cave. Courtesy National Park Concessions, Inc., photo by W. Ray Scott.

Fig. 6: Audubon Avenue, Mammoth Cave. Courtesy National Park Concessions, Inc., photo by W. Ray Scott.

Fig. 7: Map of White Cave, Mammoth Cave National Park. Survey XI. 1961 by T. C. Barr and W. E. Davies. Numbers indicate ceiling height in meters.

Fig. 8: Main gallery of Dixon Cave, Mammoth Cave National Park. Dark spots on ceiling are clusters of hibernating bats.

Fig. 9: *Carychium stygium Call; Roosevelt Dome, Mammoth Cave; length $2 \mathrm{~mm}$.

Fig. 10: *Orconectes pellucidus (Tellkampf); Cedar Sink Cave No. 3.

Fig. 11: *Palaemonias ganteri Hay; Mammoth Cave, Roaring River; length $25 \mathrm{~mm}$. Photo by Roger W. Barbour.

Fig. 12: *Kleptochthonius hageni Muchmore; Dixon Cave; length $1.5 \mathrm{~mm}$.

Fig. 13: *Phalangodes armata Tellkampf; Crystal Cave; length 2 mm.

Fig. 14: Meta menardi Latreille; White Cave; length $12 \mathrm{~mm}$.

Fig. 15: *Antriadesmus fragilis Loomis; White Cave; length $9 \mathrm{~mm}$.

Fig. 16: *Scoterpes copei (Packard); White Cave; length $15 \mathrm{~mm}$.

Fig. 17: *Plusiocampa cookei (Packard); White Cave; length $10 \mathrm{~mm}$.

Fig. 18: Hadenoecus subterraneus (Scudder); Great Onyx Cave; length 25 mm.

Fig. 19: Hadenoecus subterraneus, mating pair; Mammoth Cave, November, 1963. 
Speleology III. Barr, Jr.

Fig. 20: Psyllipsocus ramburi Sélys-Longchamps; "Mushroom Beds", Mammoth Cave; length $2.5 \mathrm{~mm}$.

Fig. 21: *Neaphaenops tellkampfii (Erichson); Great Onyx Cave; length $7 \mathrm{~mm}$.

Fig. 22: *Batrisodes henroti Park; White Cave; length $2.5 \mathrm{~mm}$.

Fig. 23: *Amblyopsis spelaea DeKay; Thornhill Cave, Kentucky; length $90 \mathrm{~mm}$.

Fig. 24: *Typhlichthys subterraneus Girard; Roaring River, Mammoth Cave; length $50 \mathrm{~mm}$.

Fig. 25: Eurycea lucifuga Rafinesque; Great Onyx Cave; length $175 \mathrm{~mm}$, including tail.

Fig. 26: Bats (Myotis lucifugus, M. sodalis) hibernating in Long Cave, Mammoth Cave National Park; November, 1963.

Fig. 27: Pipistrellus subflasus (F. Cuvier); Martel Avenue, Mammoth Cave.

Fig. 28: Sterile mycelium, Rhizomorpha sp., on rotting wood; Great Onyx Cave. 


\section{ADDENDA}

Gastrotricha. - A few specimens of an undetermined genus and species of Chaetonotidae were found in silt in the bottom of rimstone pools near the entrance in Great Onyx Cave.

Oligochaeta. - Immature lumbriculids, not further identified, inhabit rotting wood in upper levels of the caves; they are apparently eaten by trechines. The limicolous worms along the rivers also include enchytraeids.

Isopoda. - Lirceus fontinalis is abundant in a small stream issuing from a little cave above Styx River outlet.

Amphipoda. - *Crangonyx packardi also occurs in pools in Buzzard Cave on Flint Ridge.

Collembola. - A small colony of *Arrhopalites altus has recently been discovered in Logsdon Valley Cave, north of Green River, 3 miles west of Munfordville, Hart Co., Kentucky. ${ }^{*}$ Sinella cavernarum coexists in the same cave.

Coleoptera. - *Pseudanophthalmus pubescens and $* P$. inexpectatus were taken in White Cave in September, 1967, following an unusually wet, cool summer (Barry Moore and T. C. Barr). 


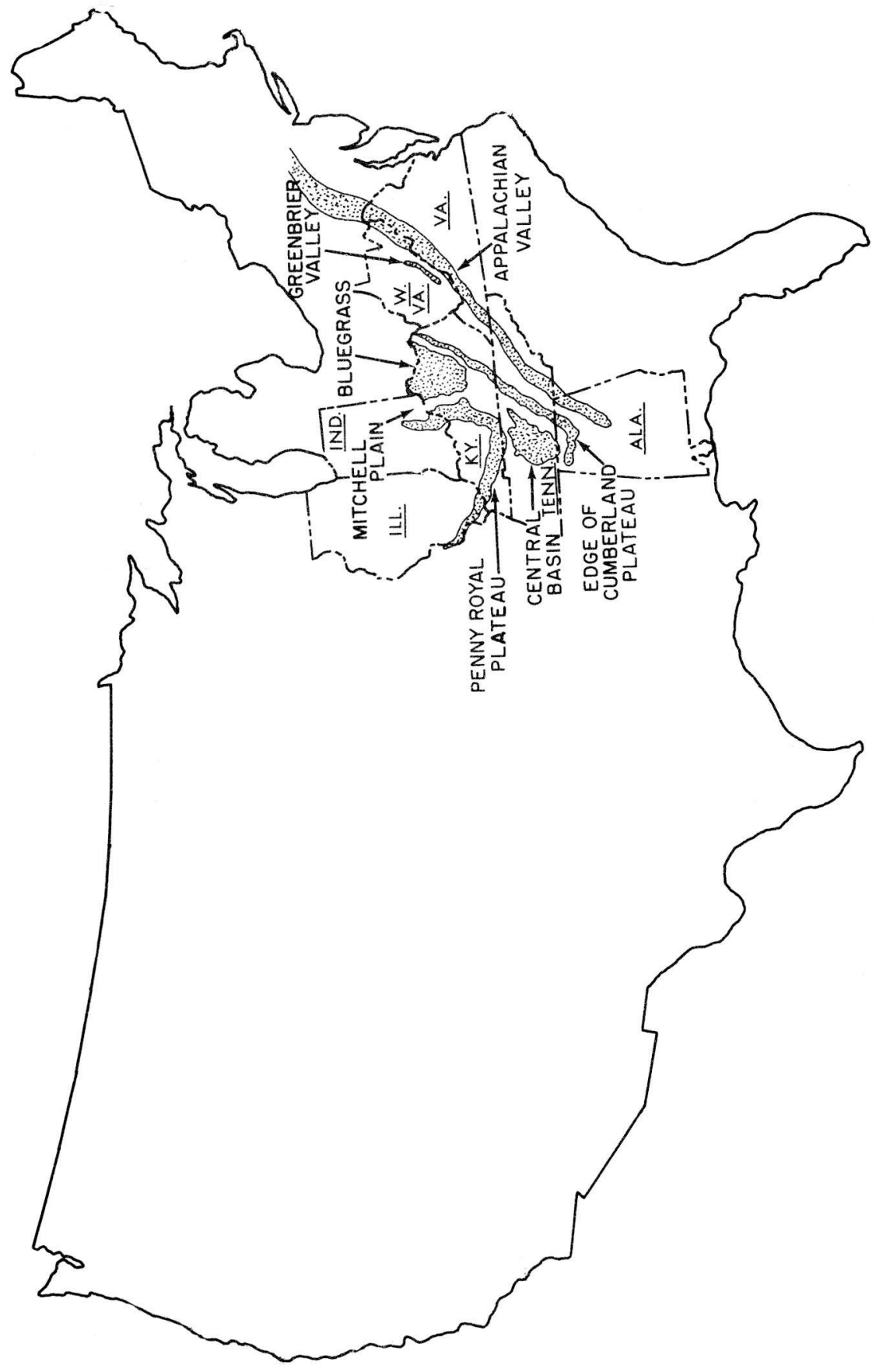




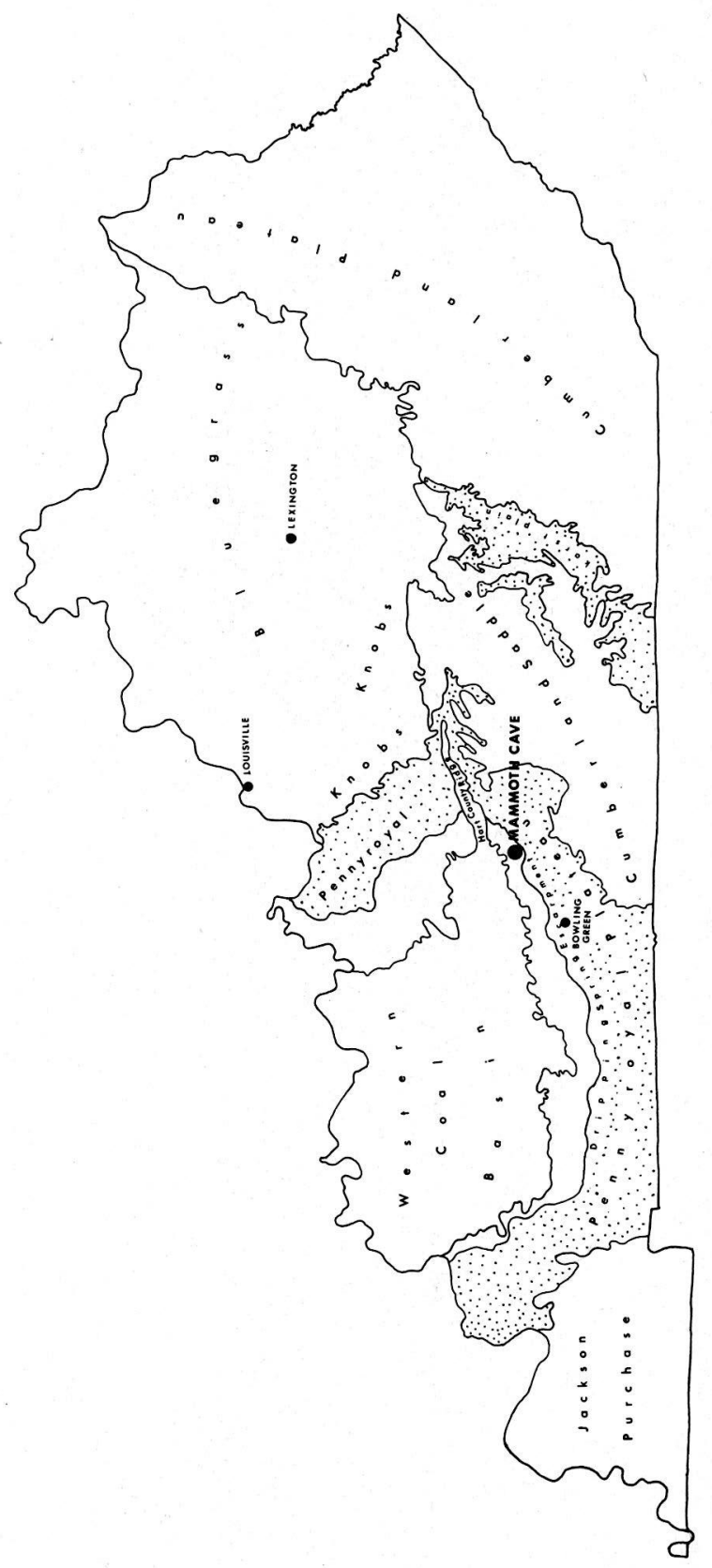




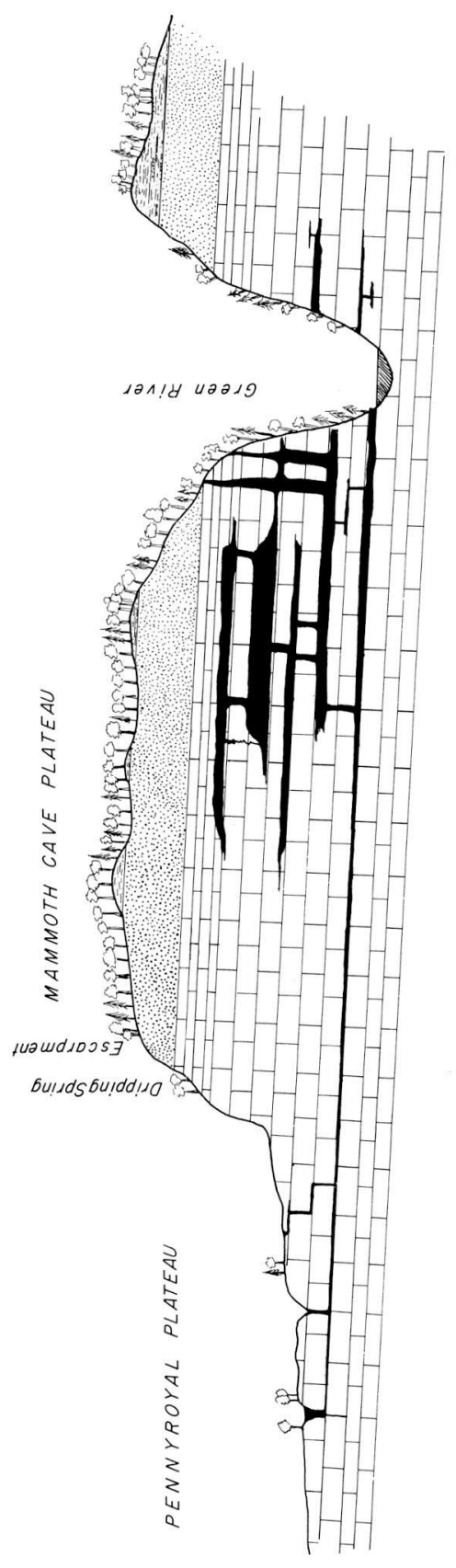




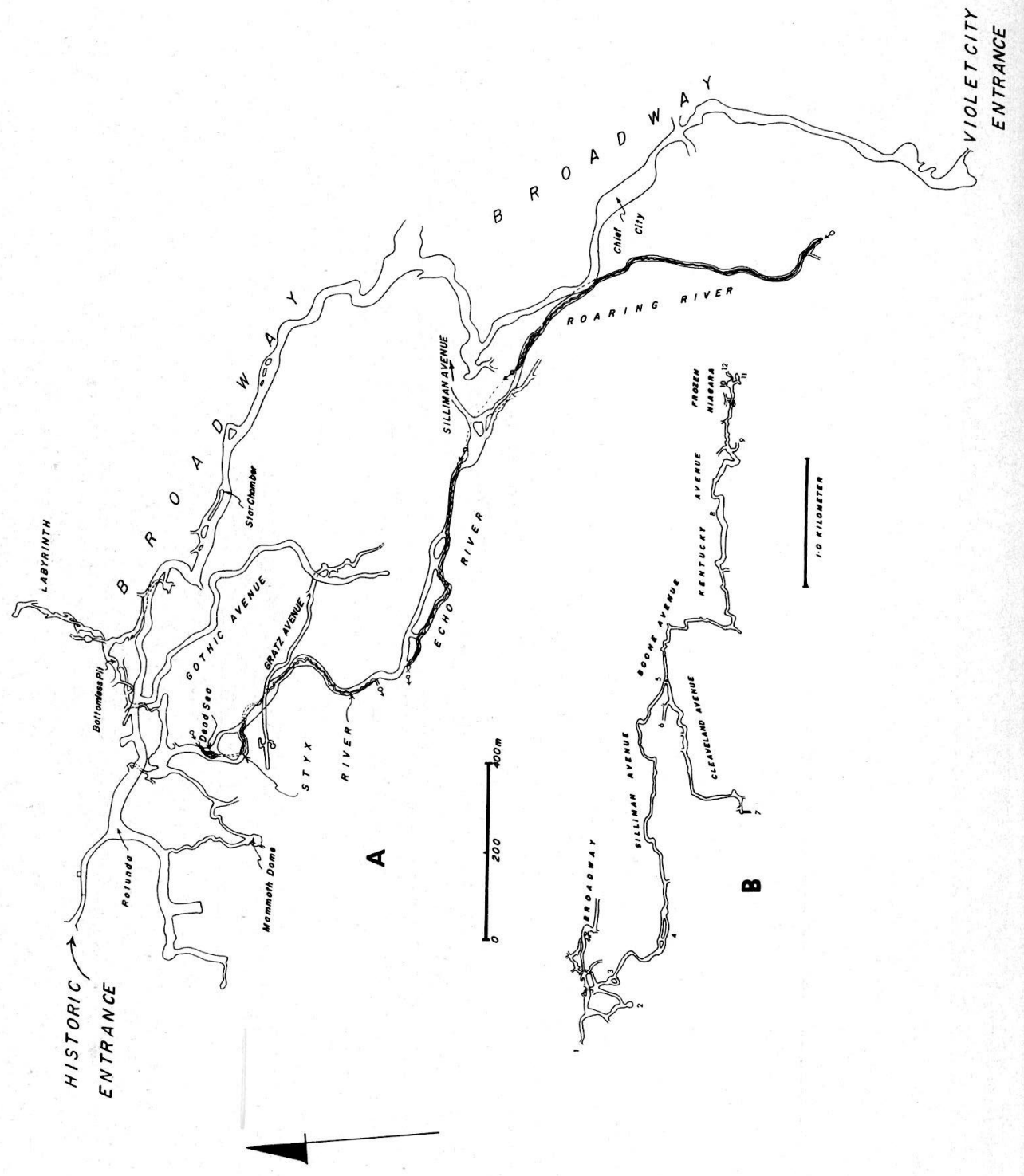




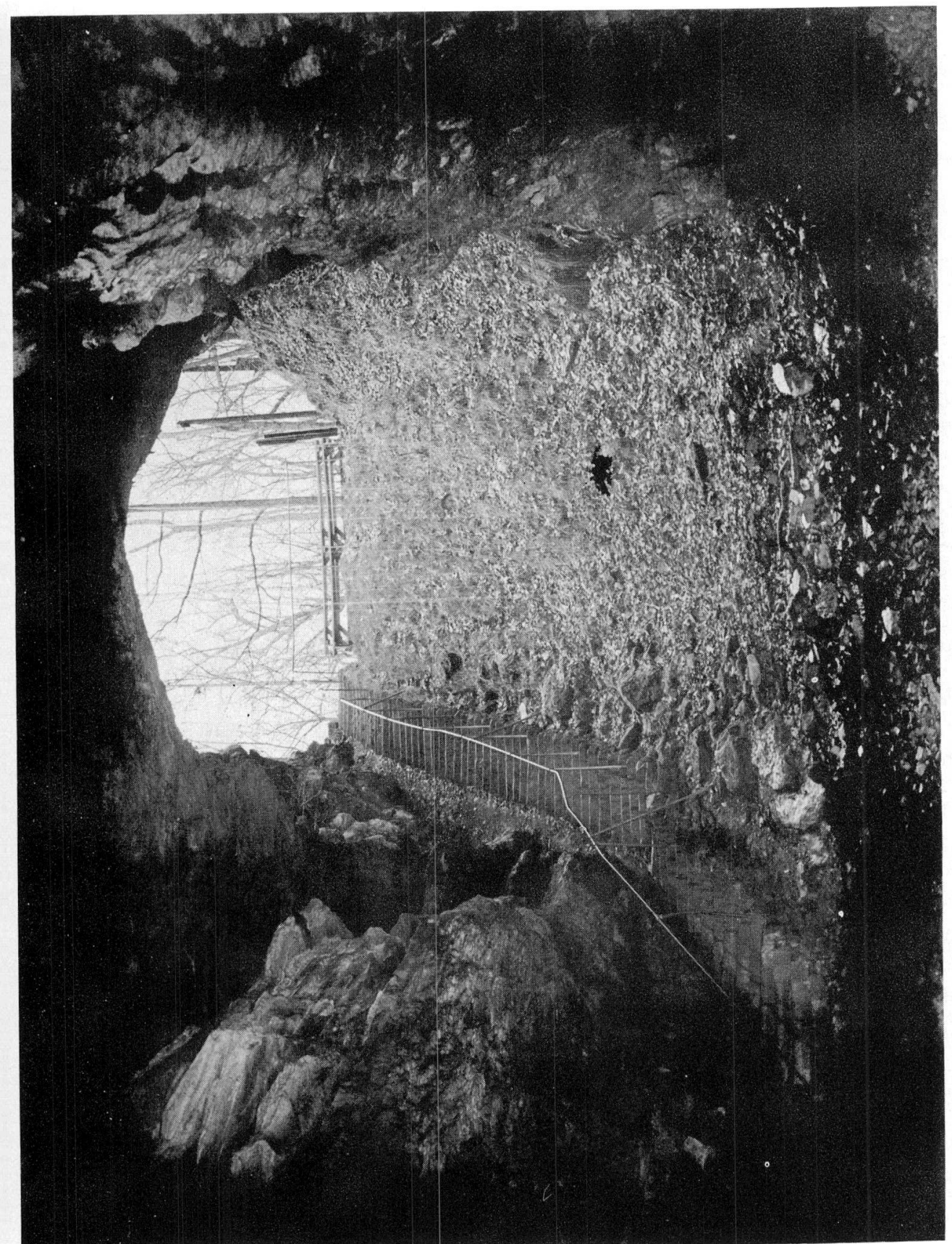




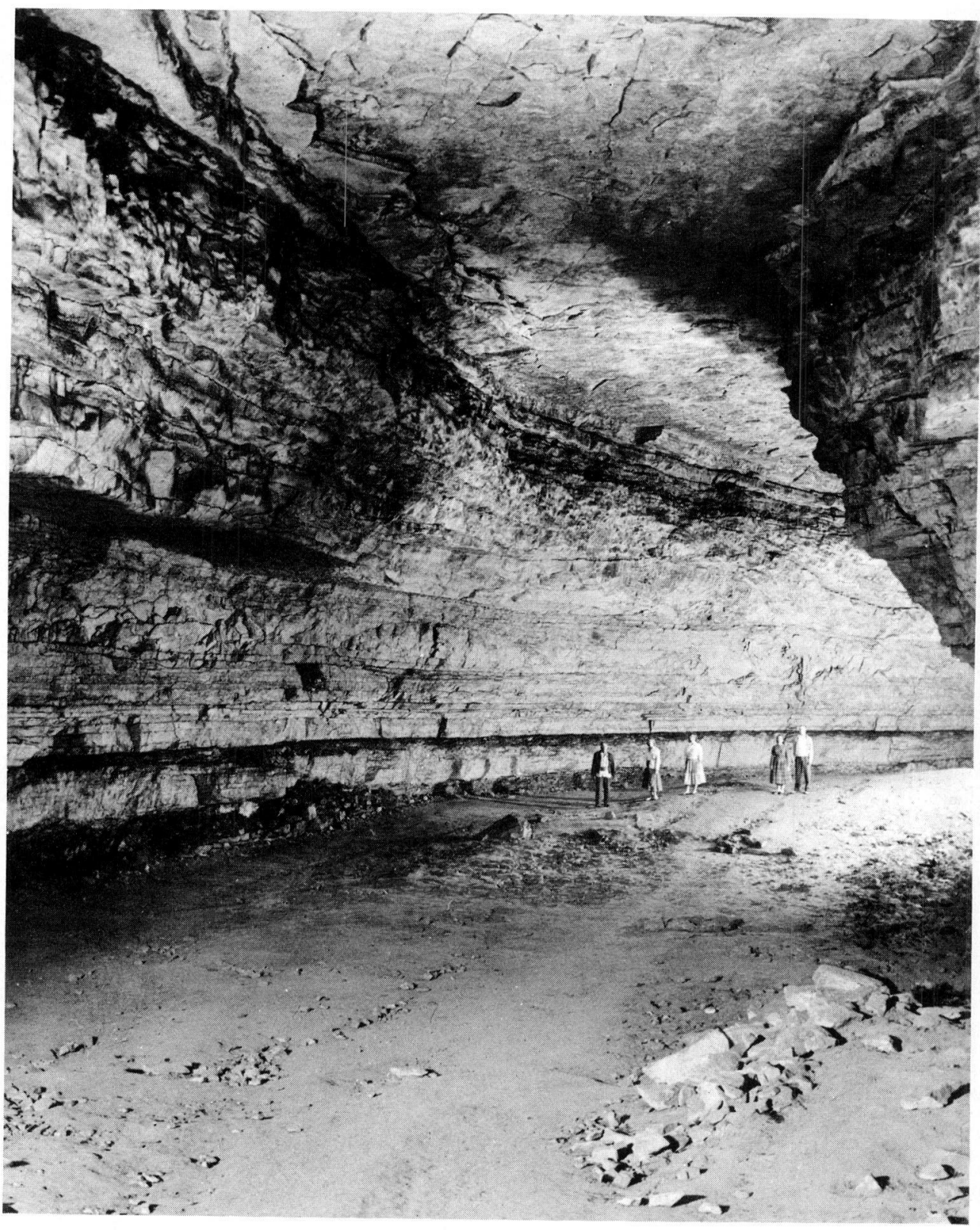




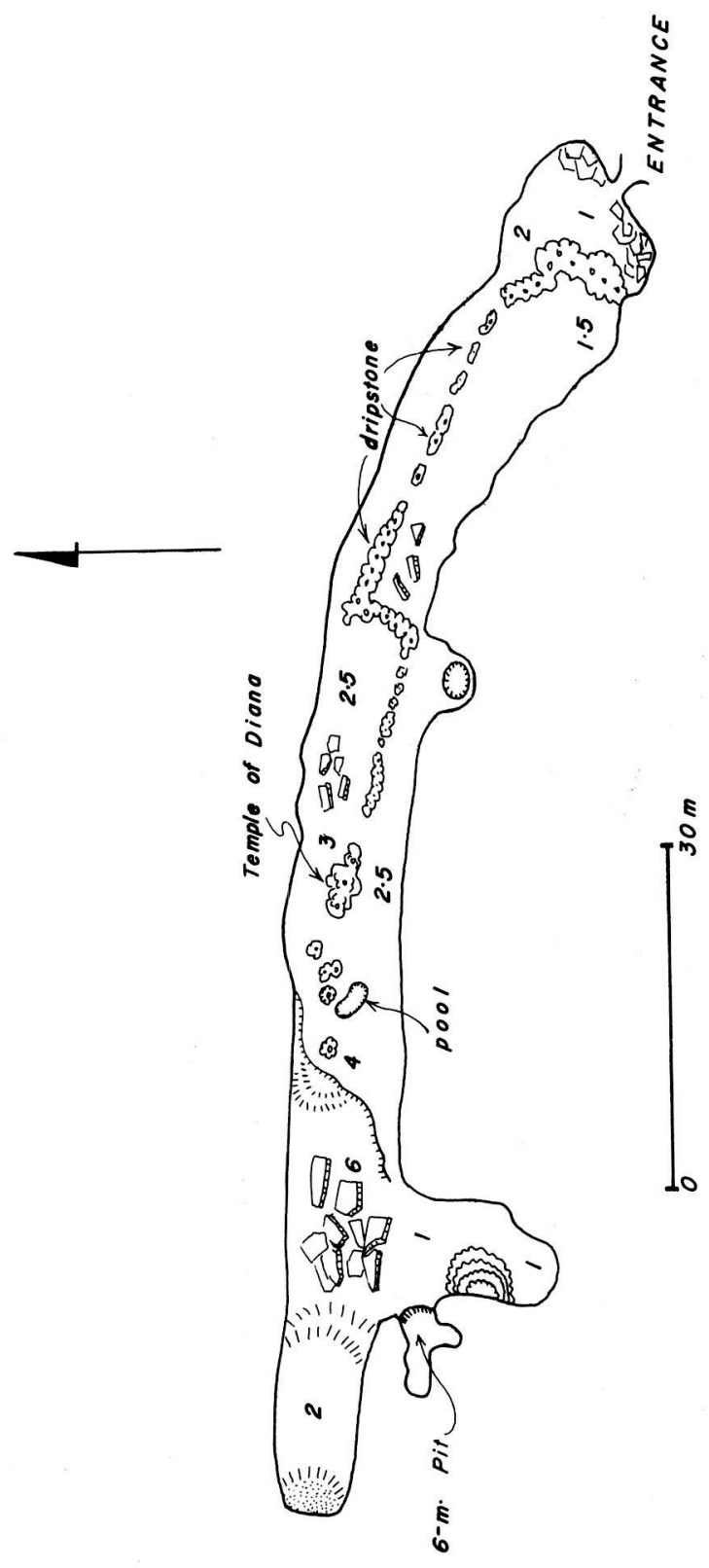




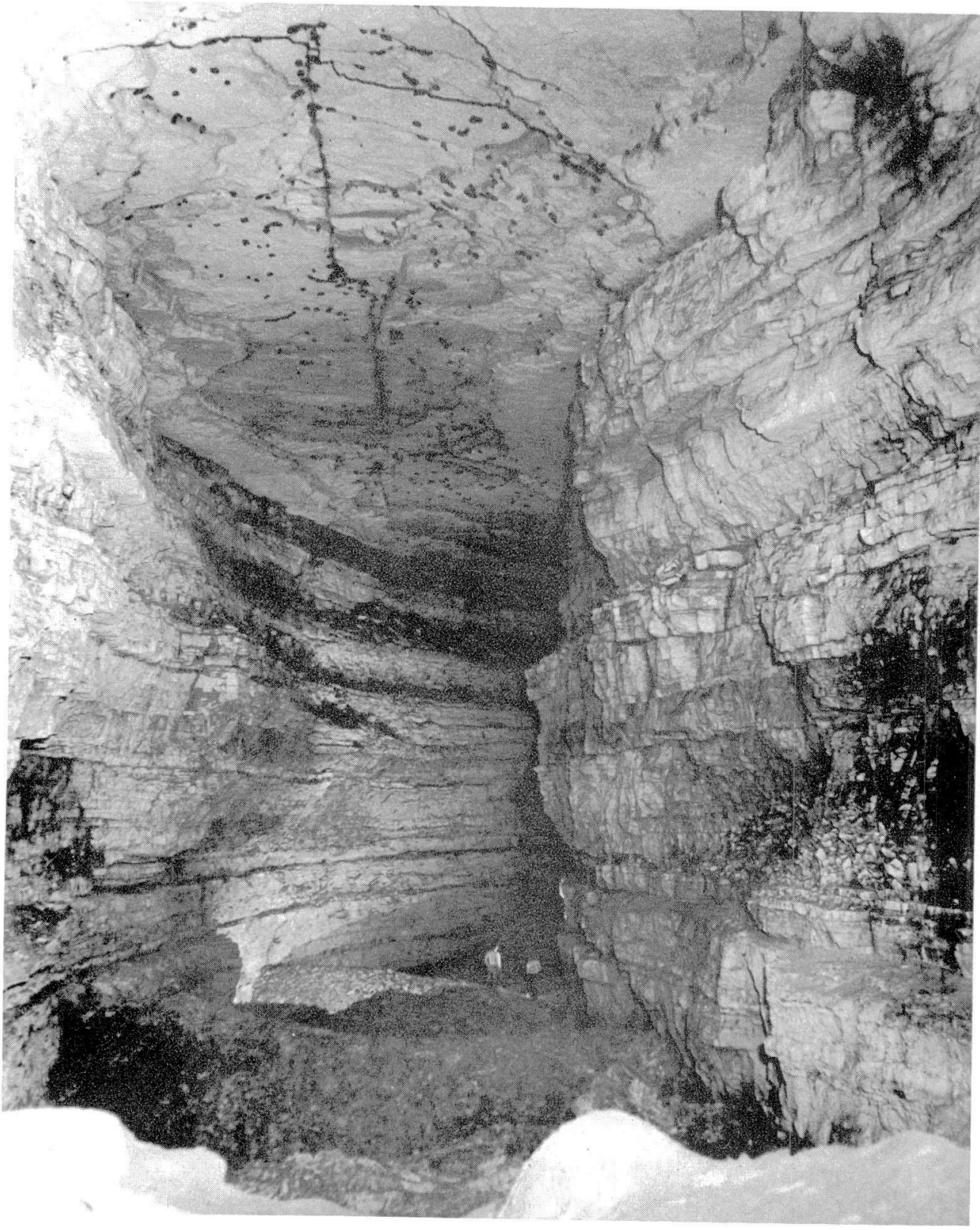




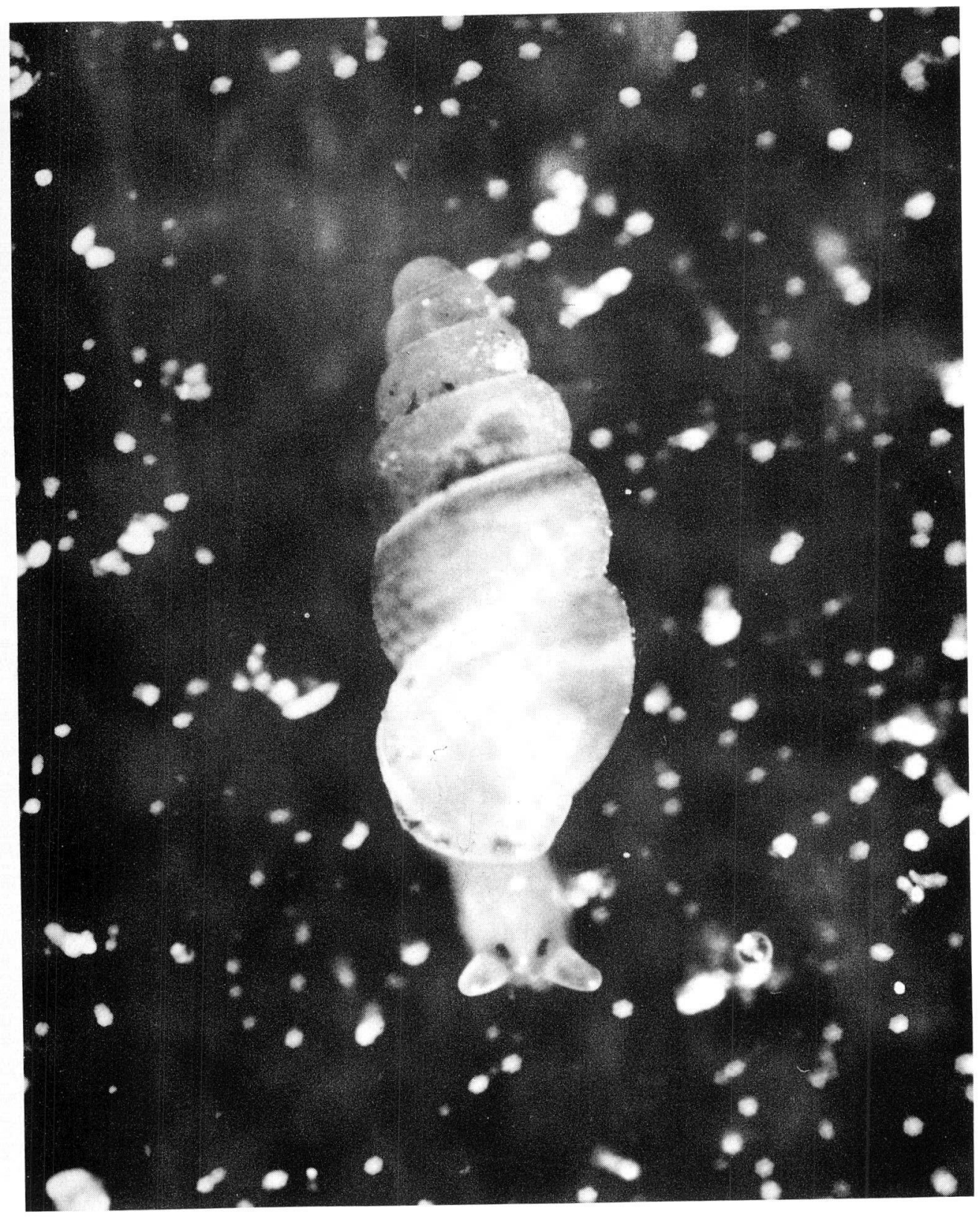




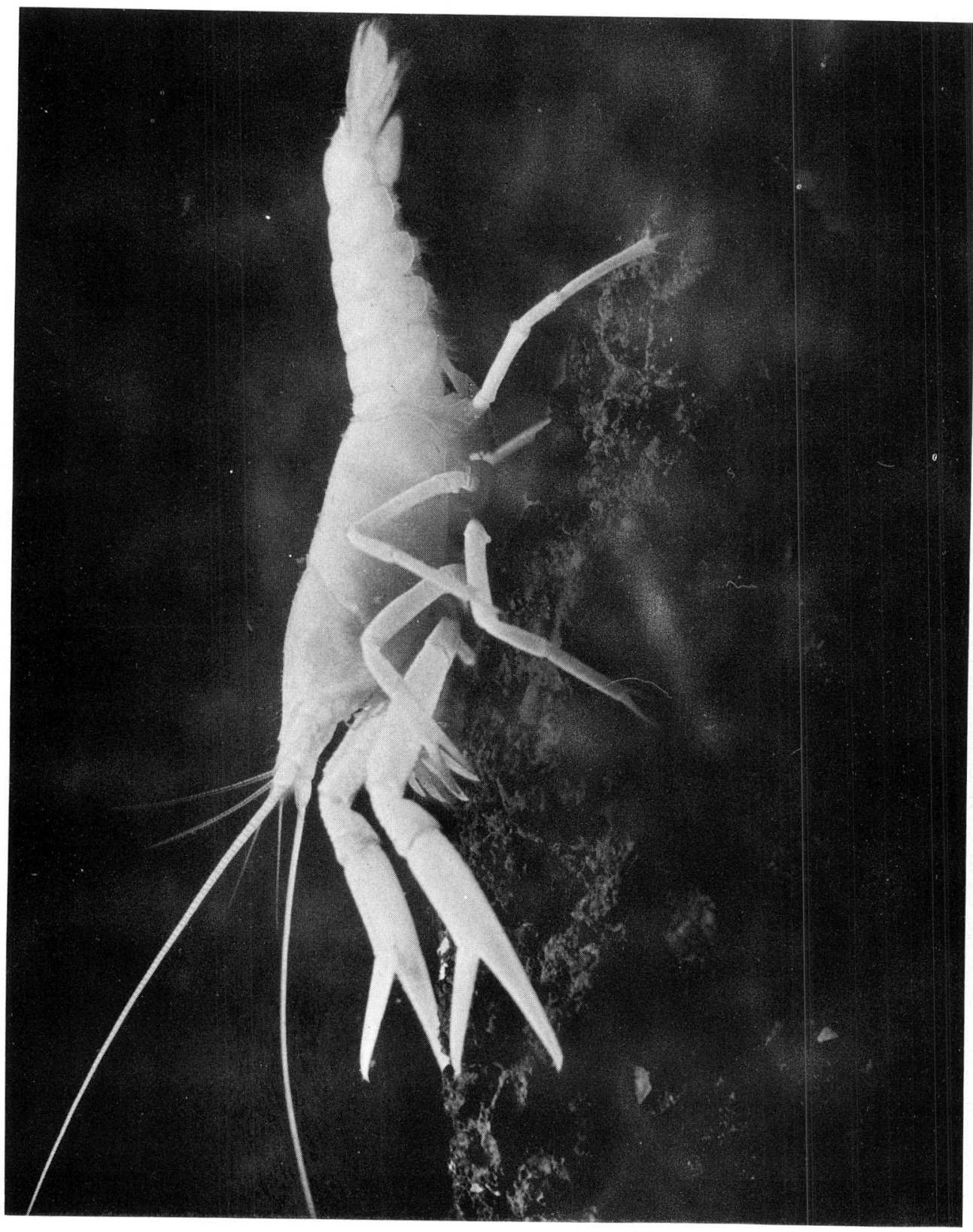




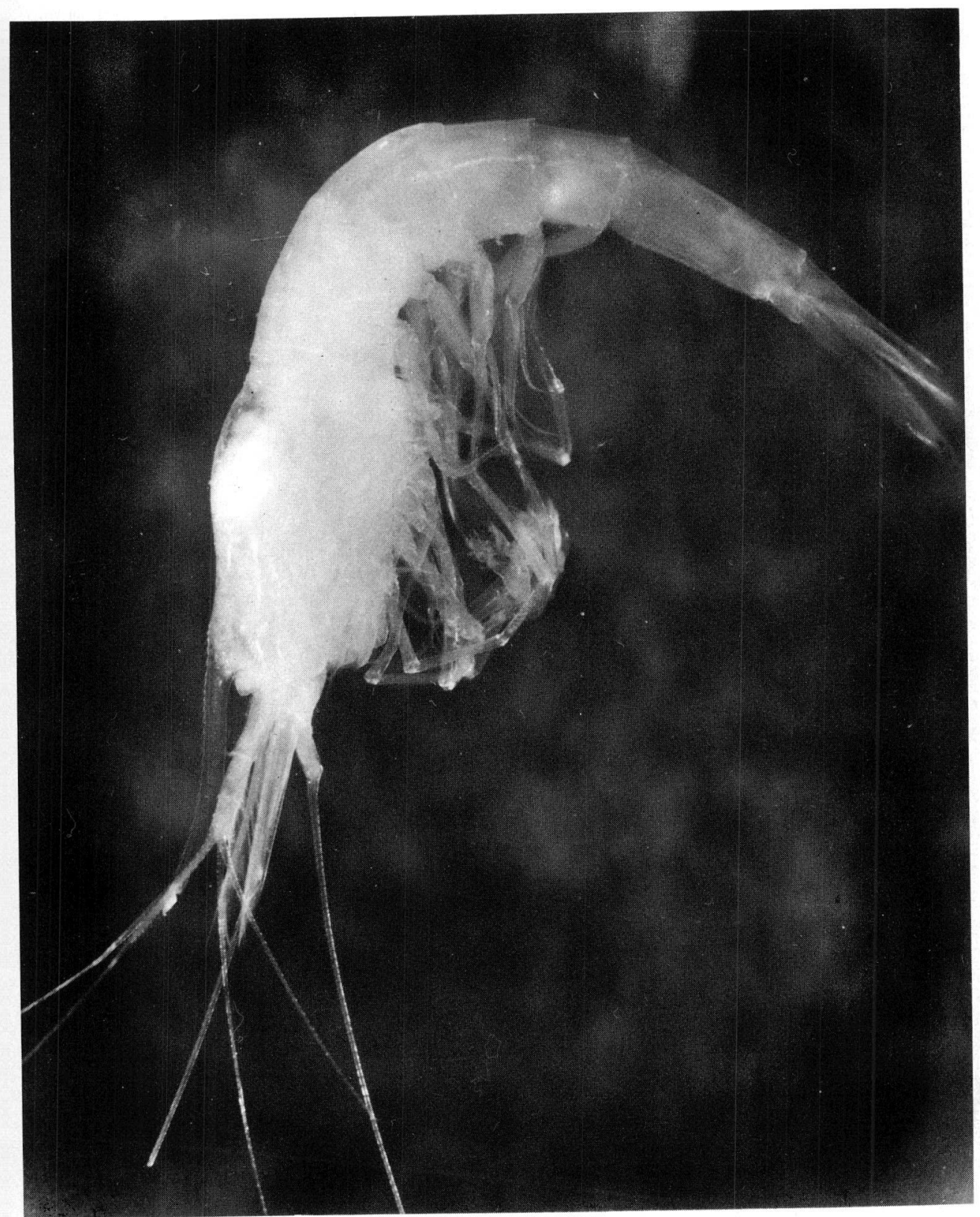




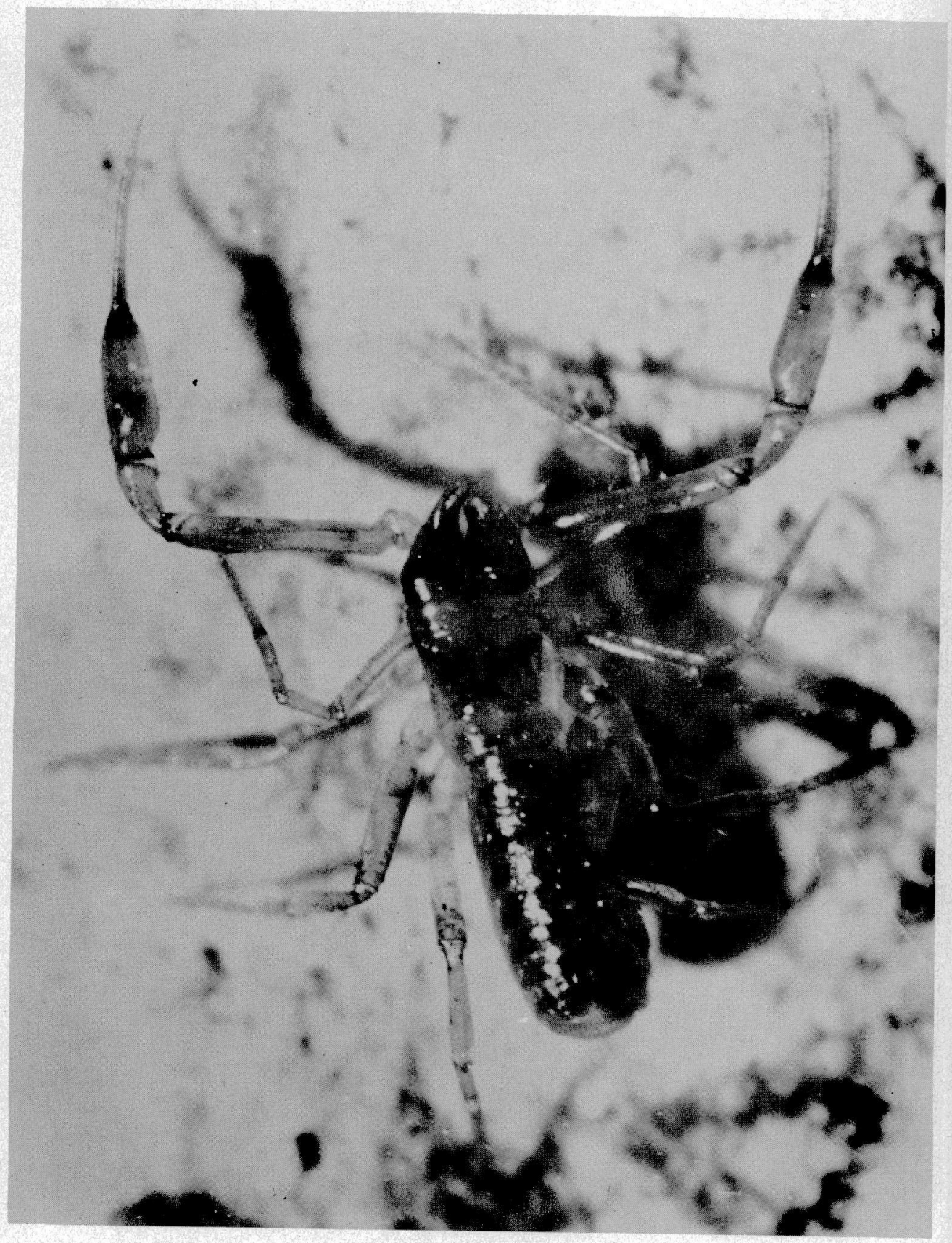




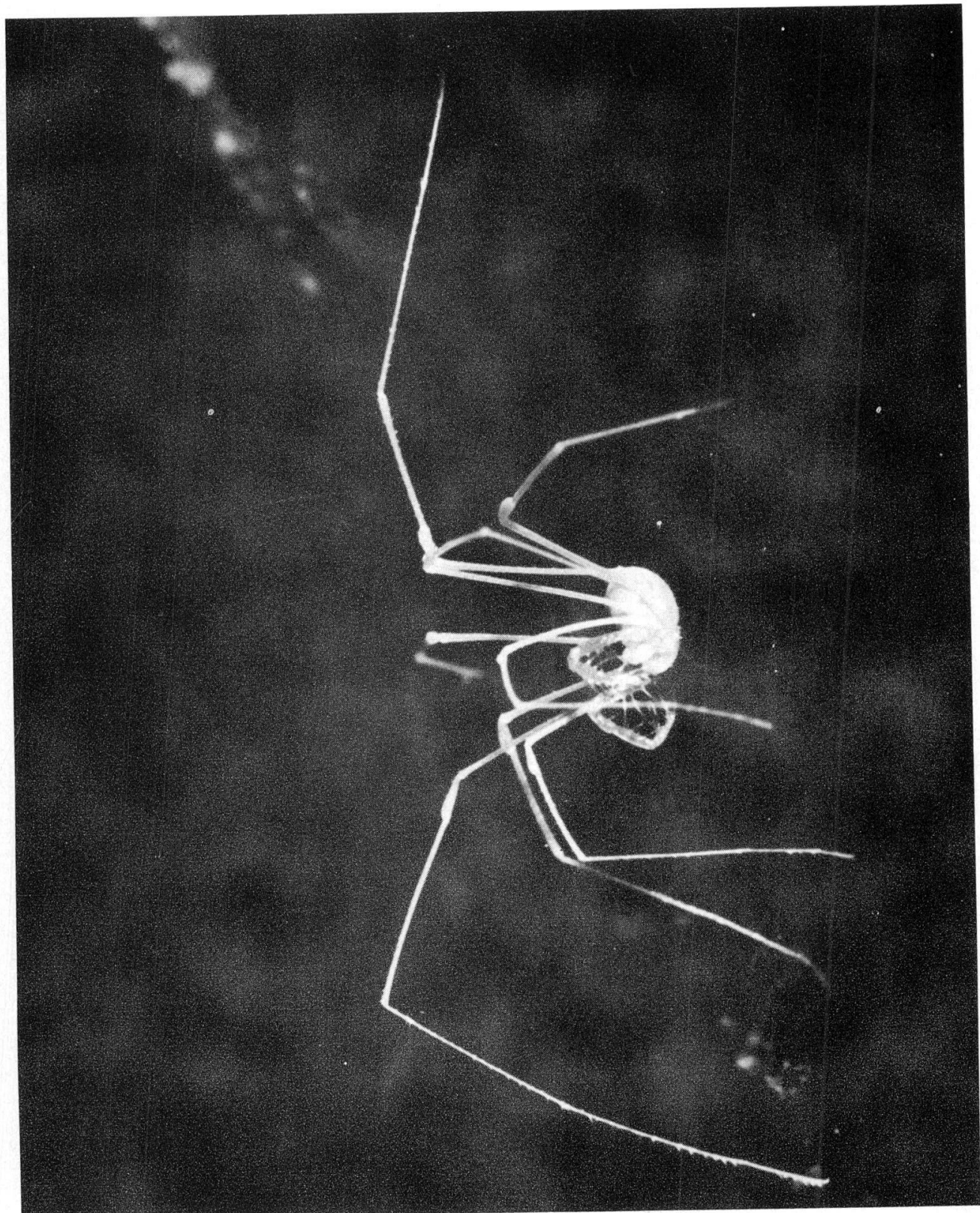




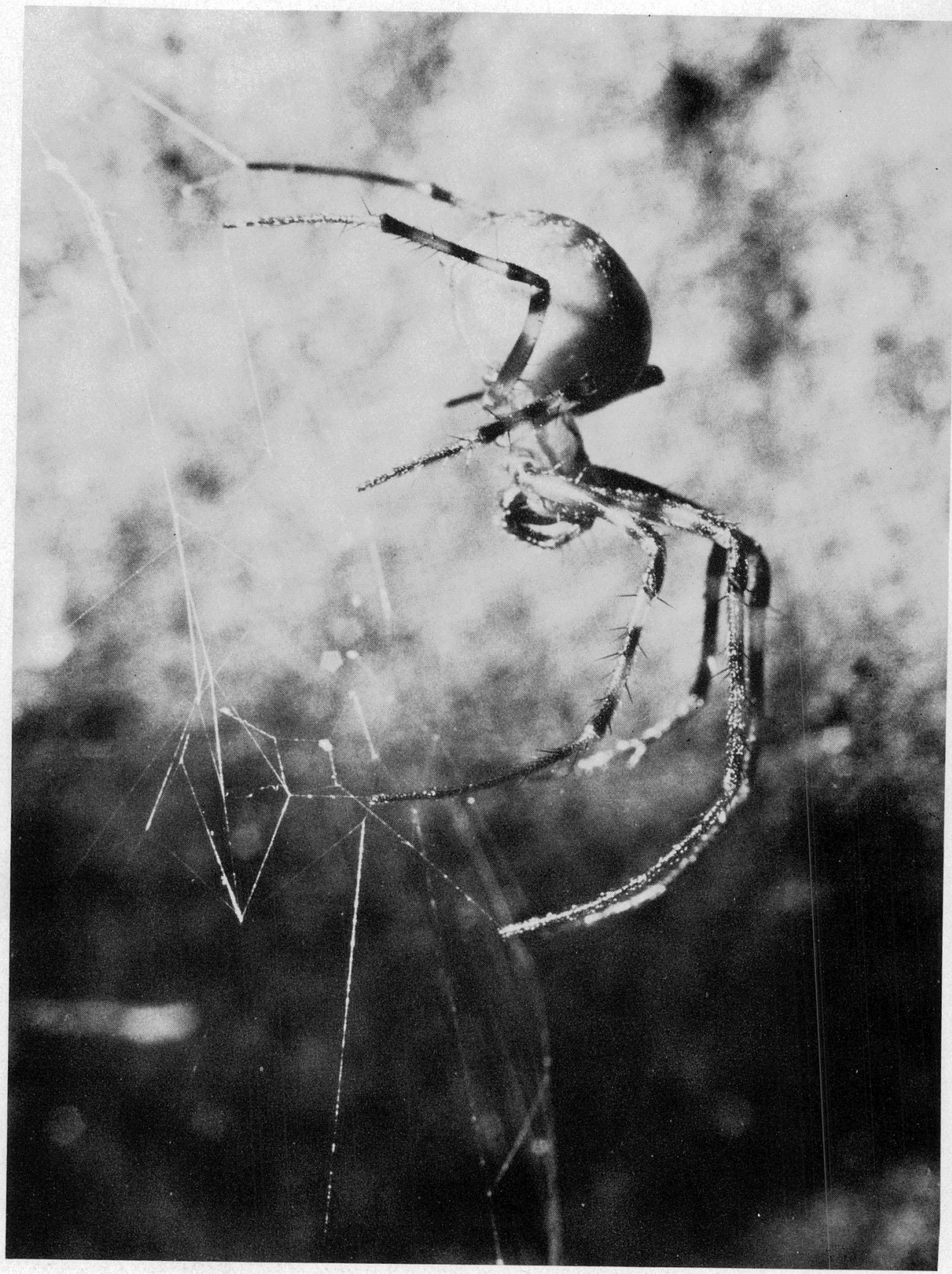




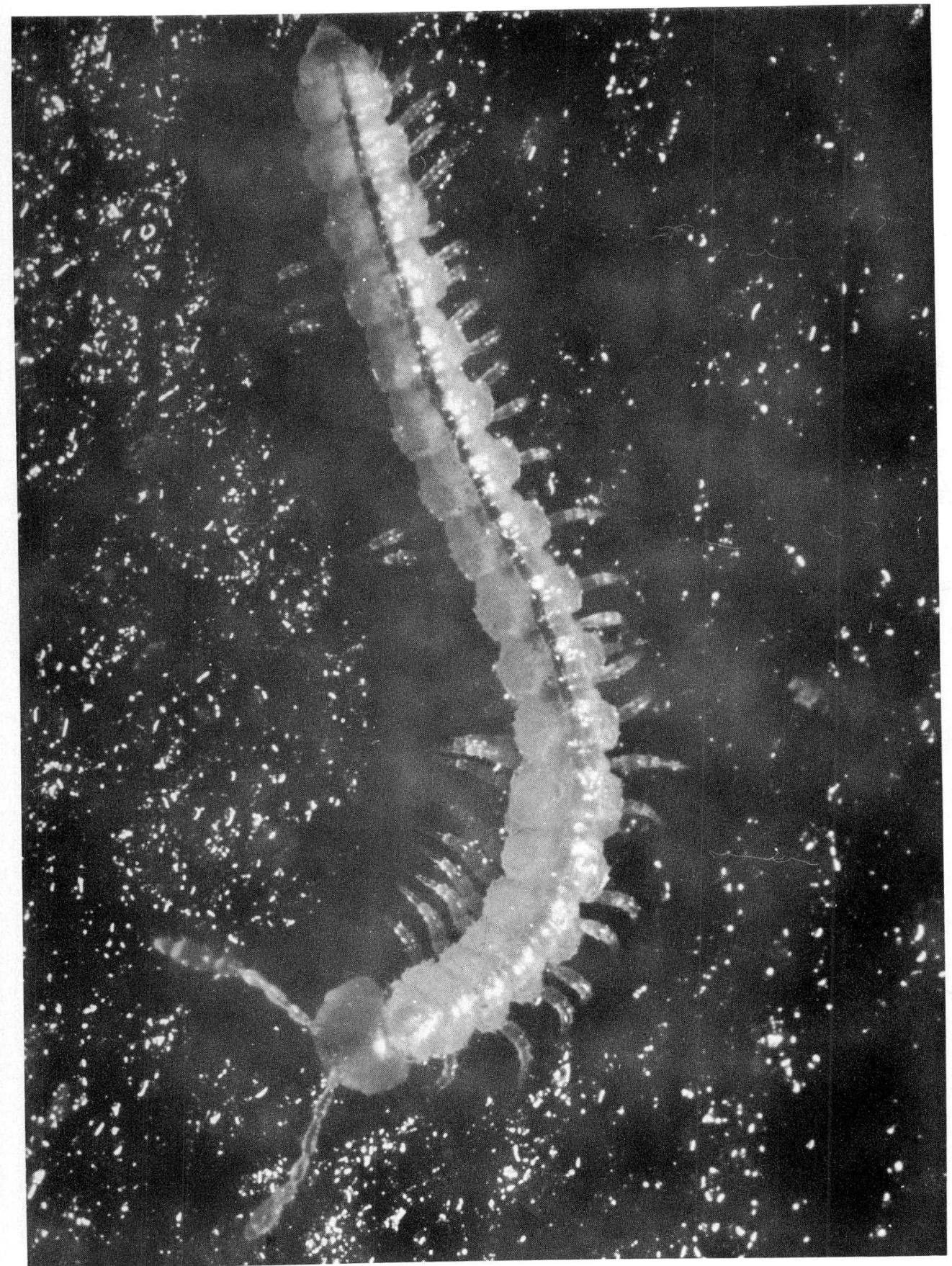




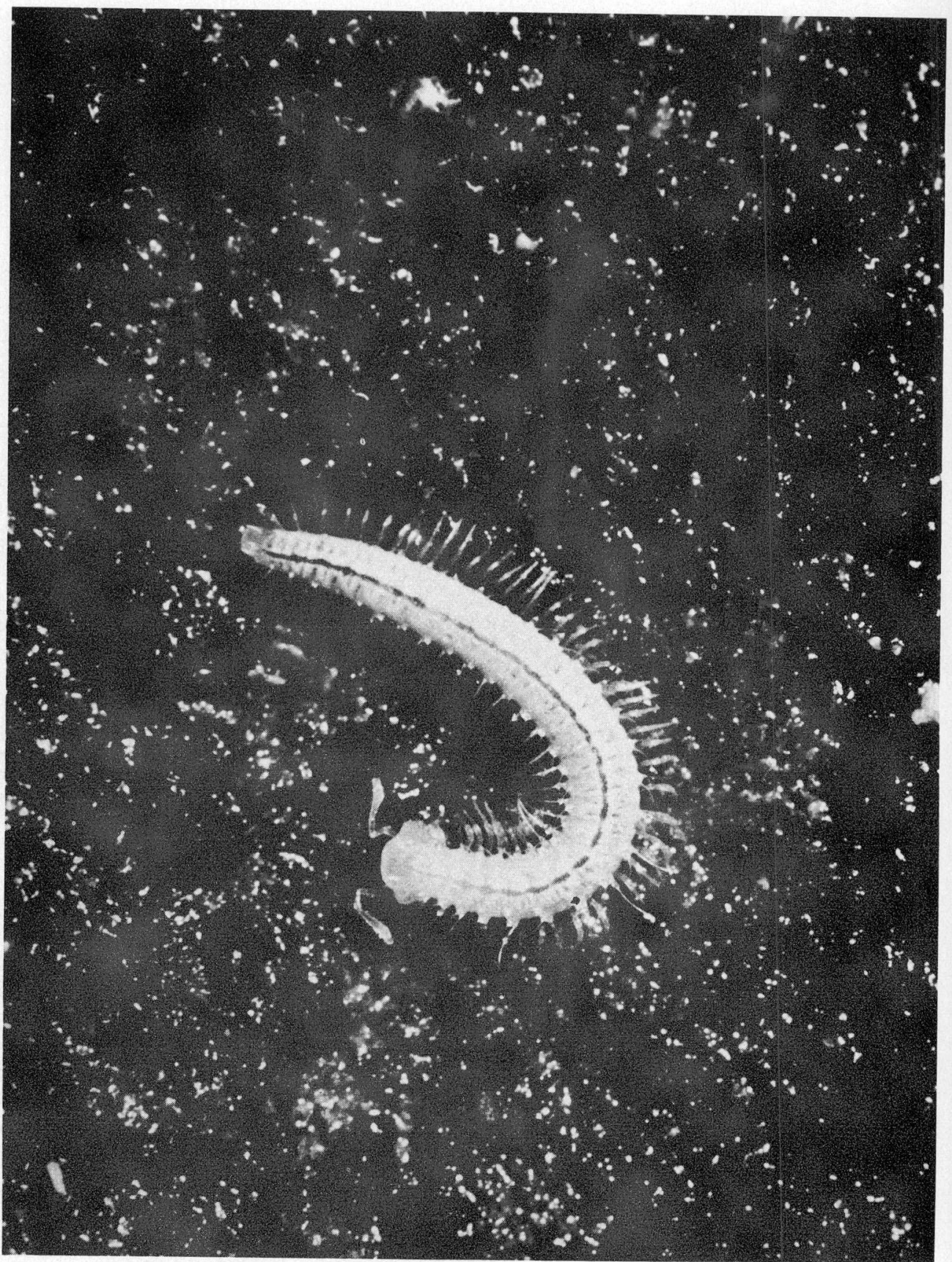




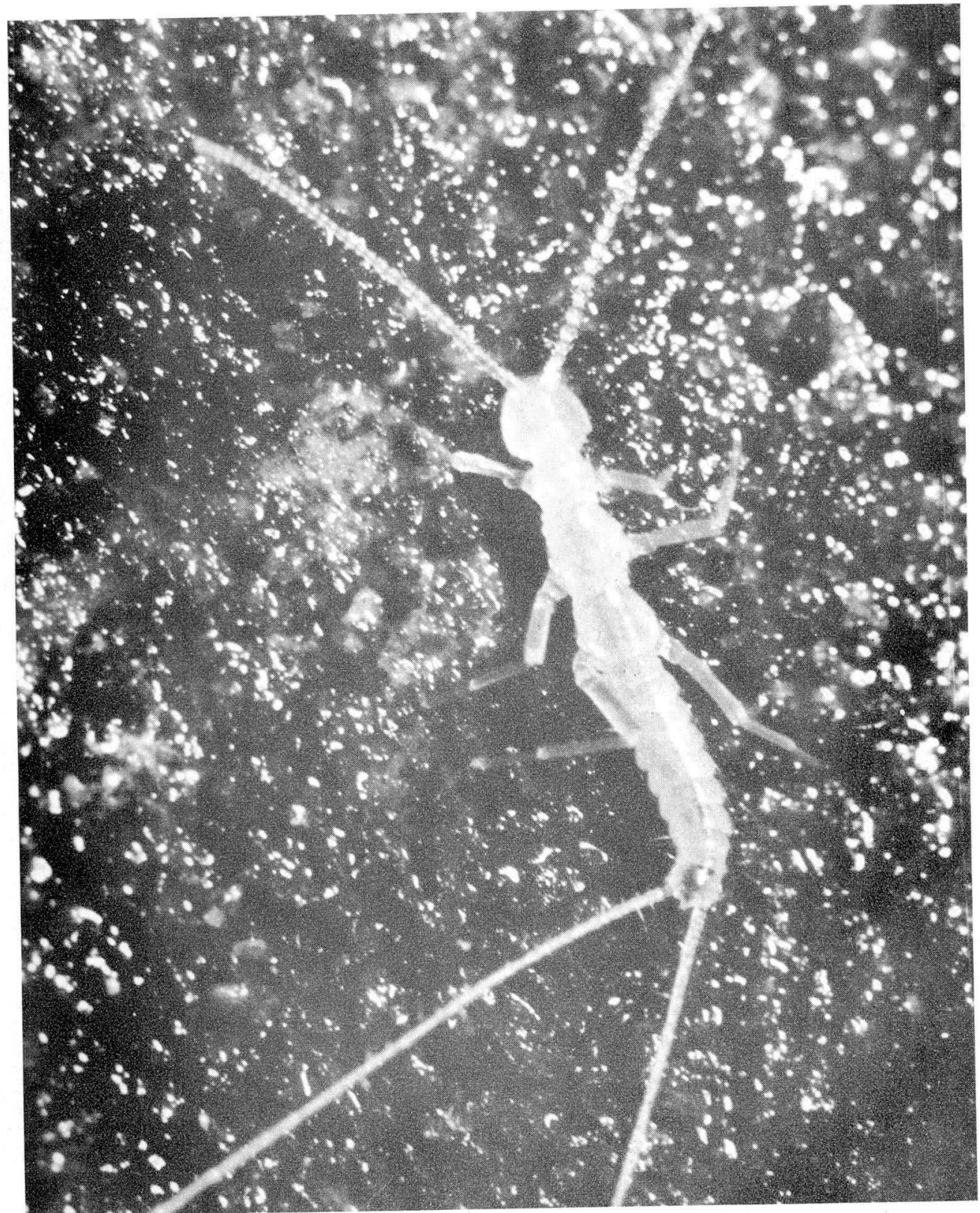




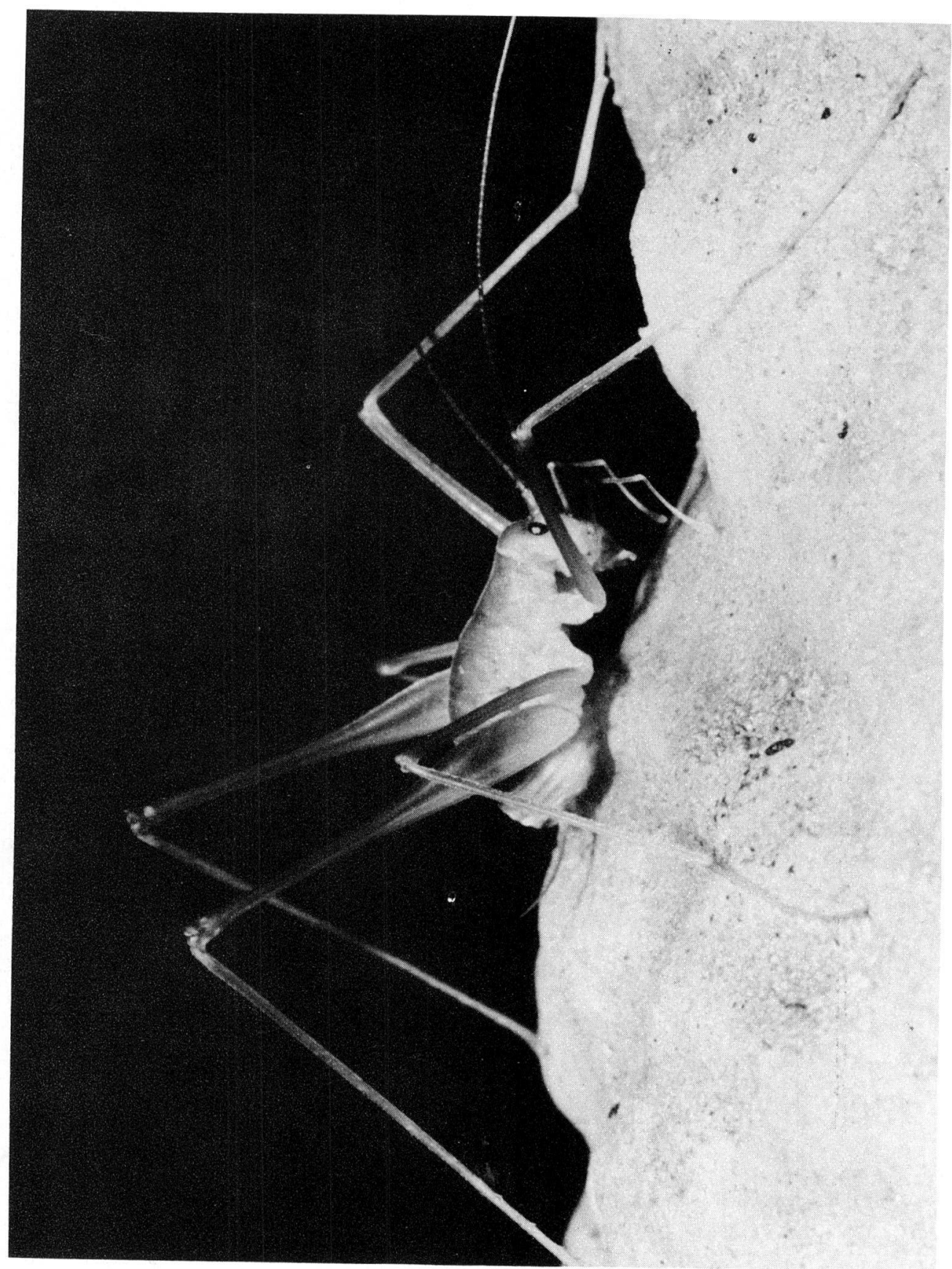




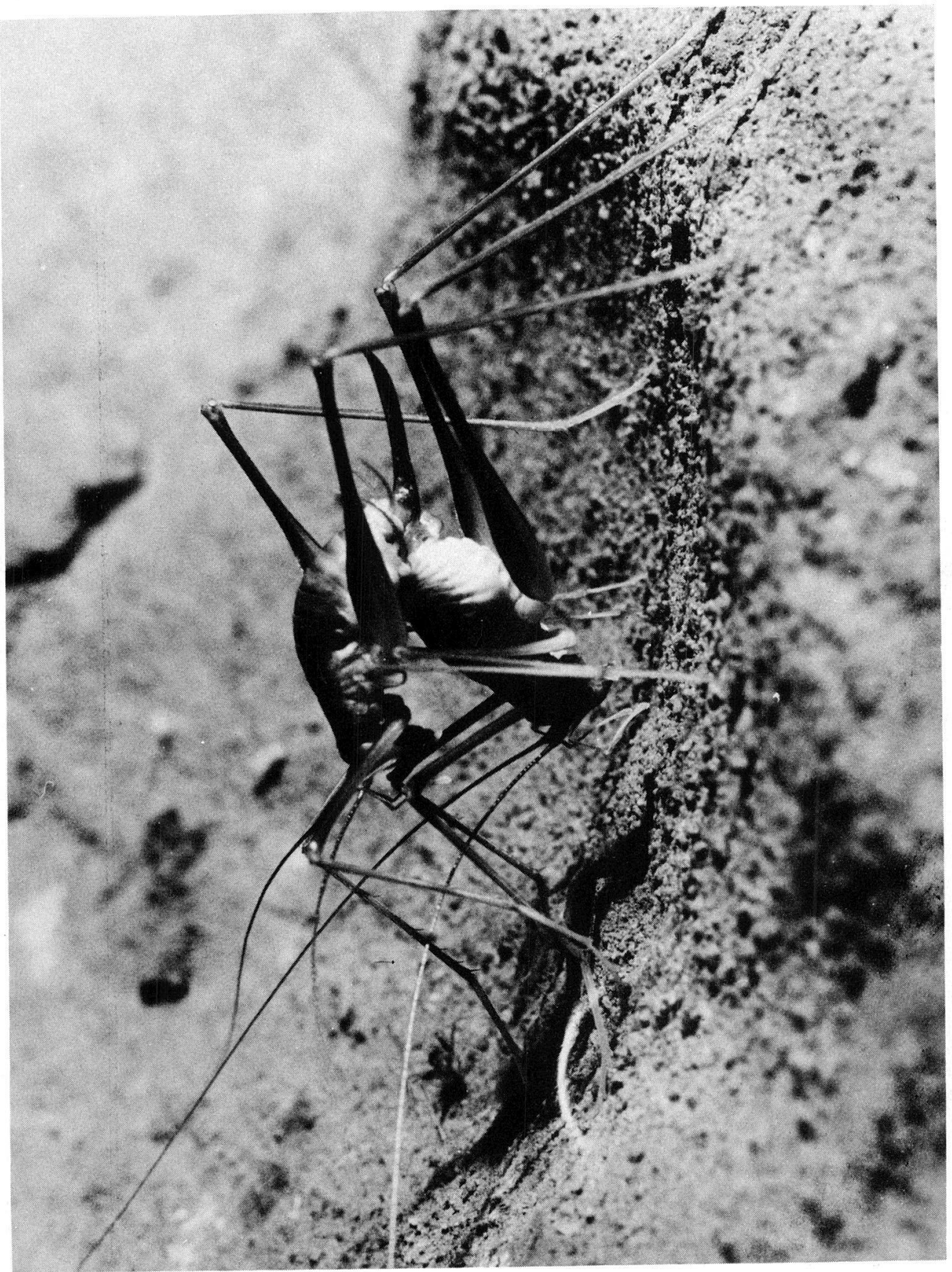




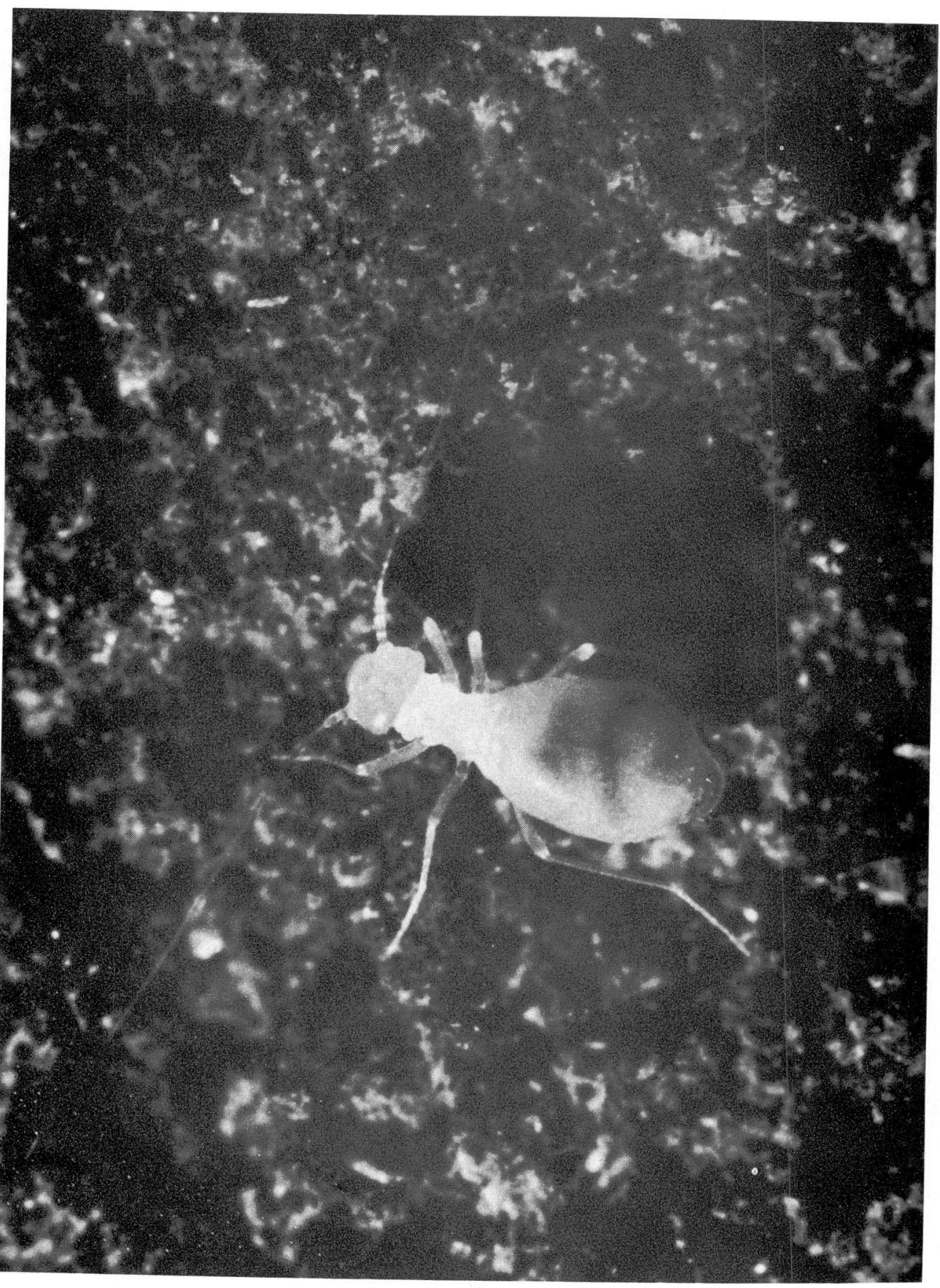




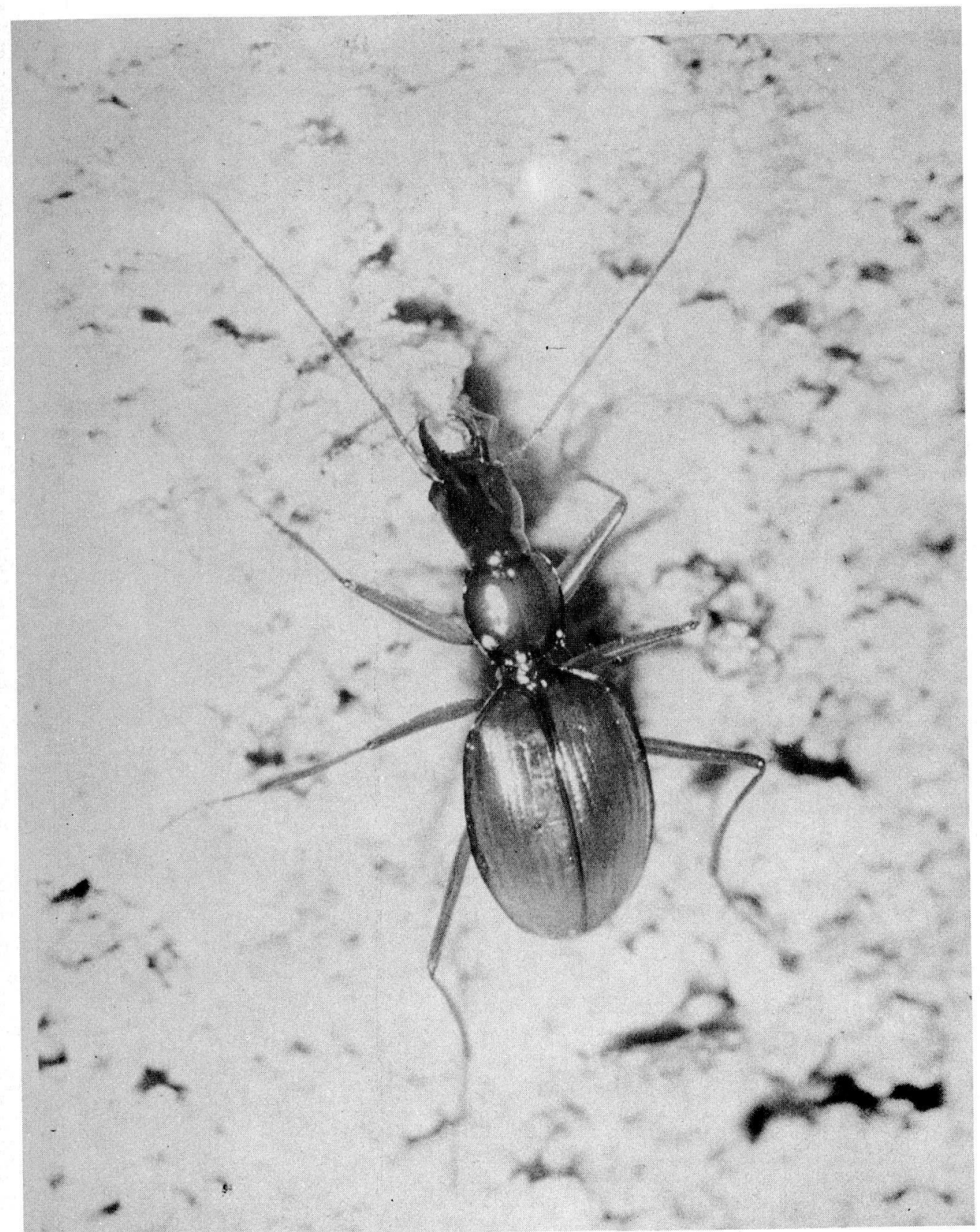




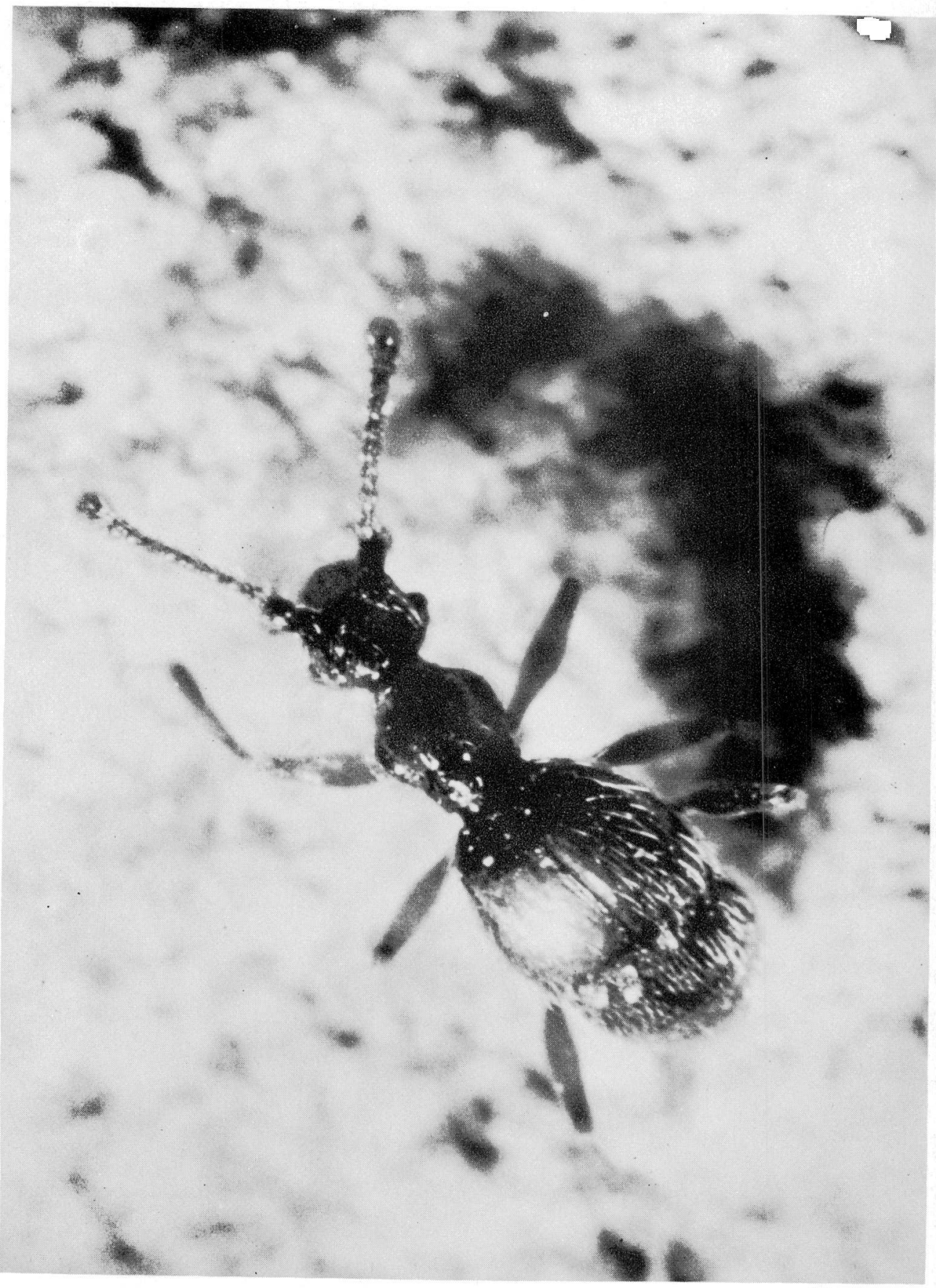




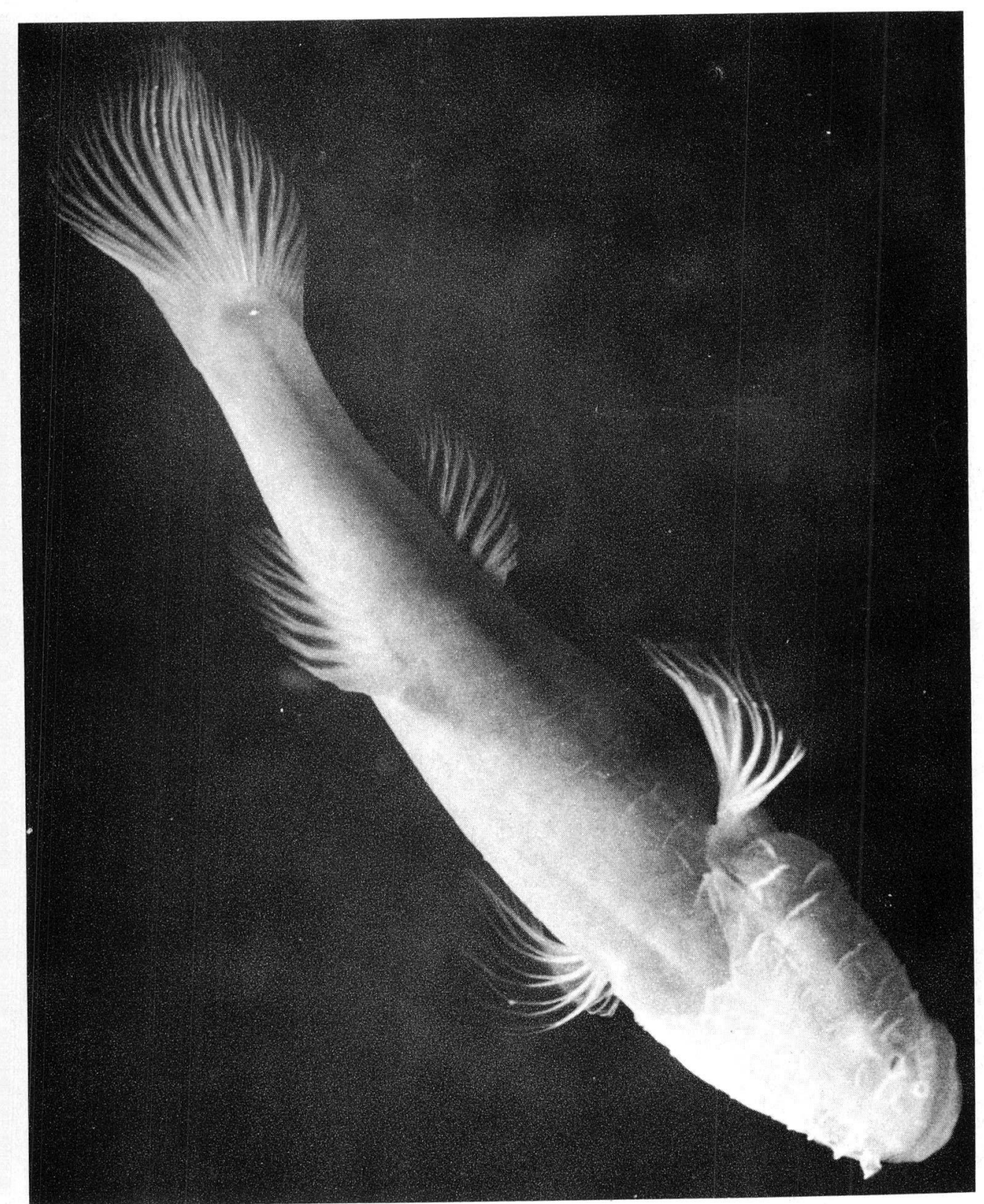




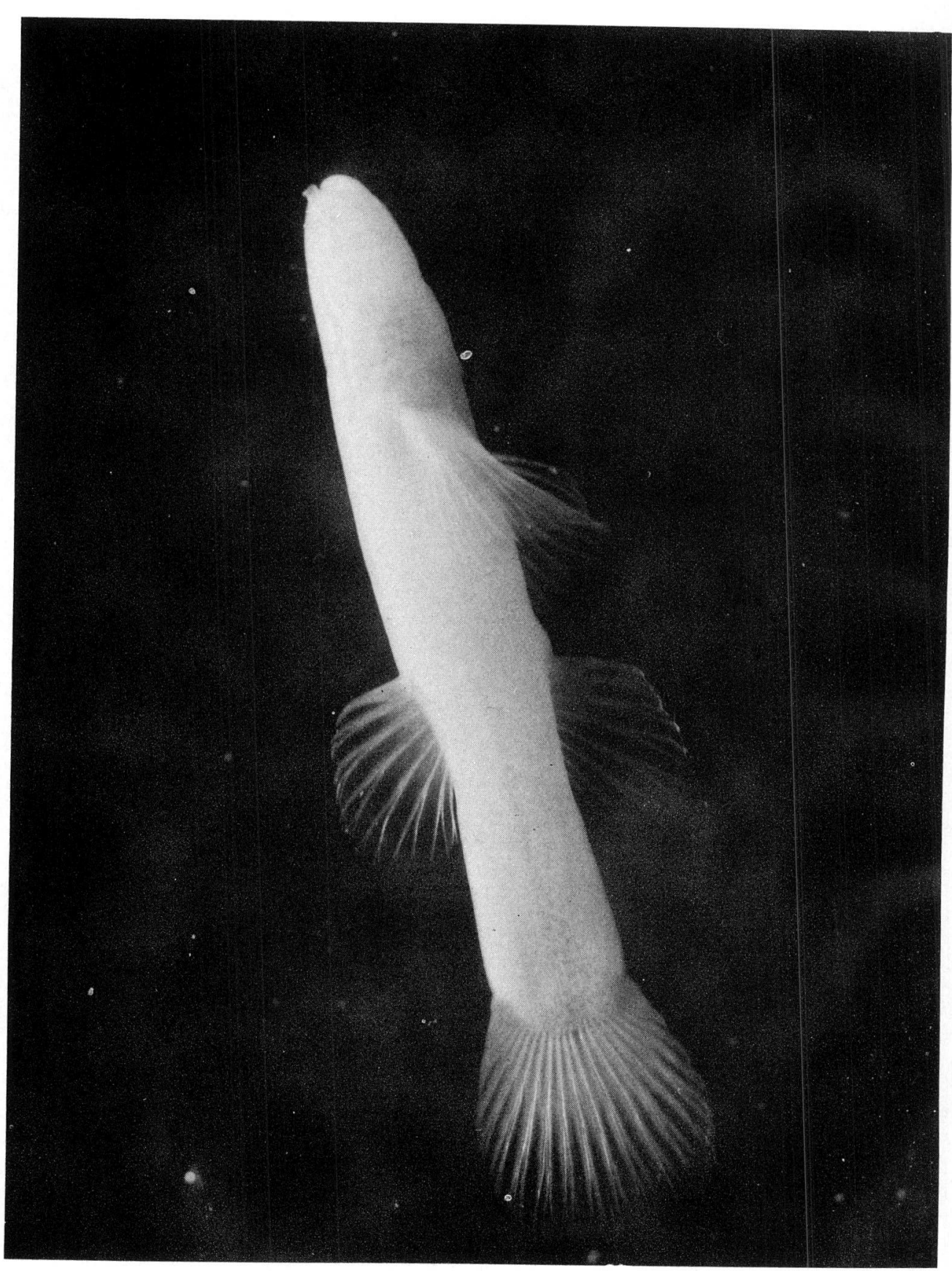




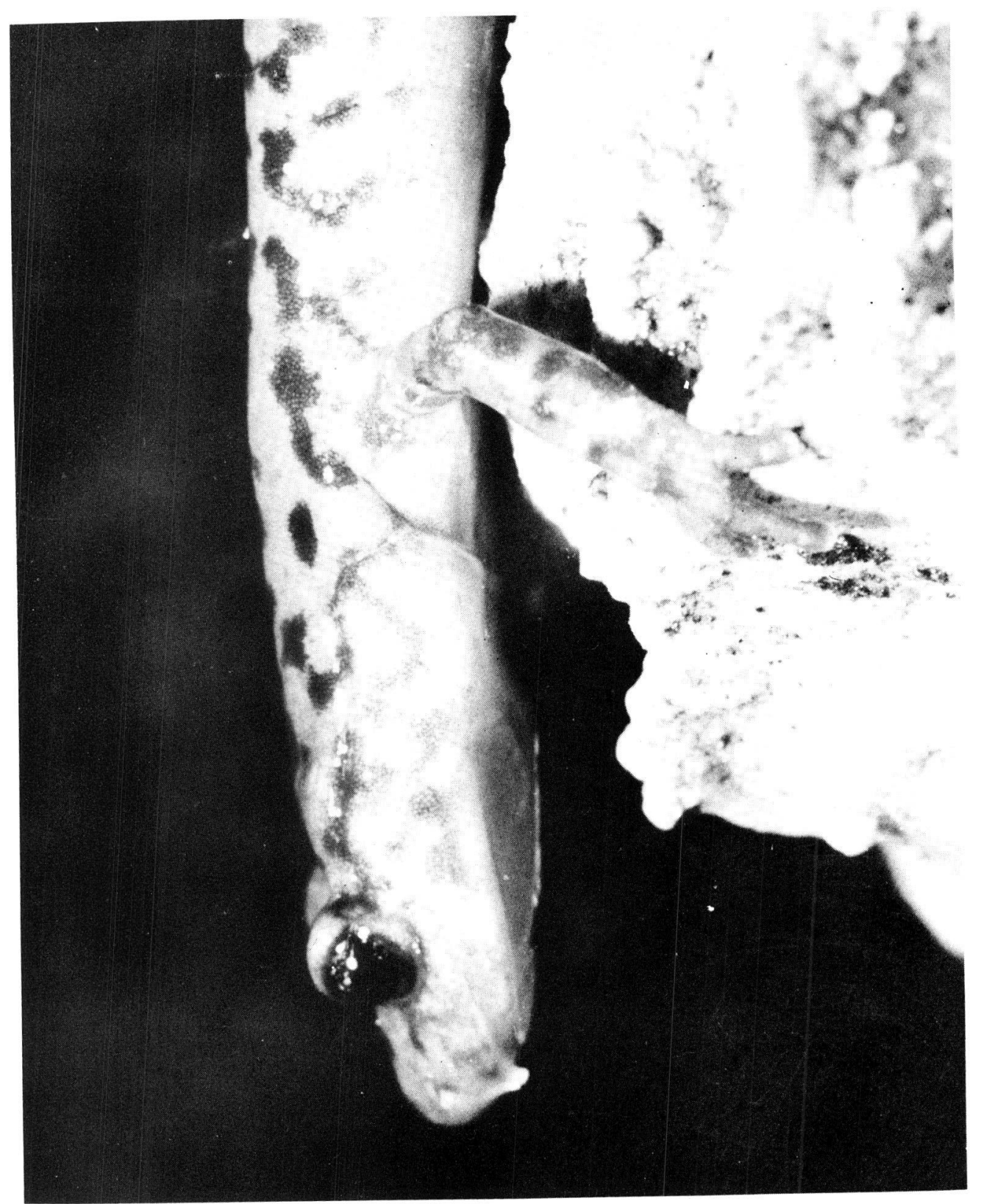




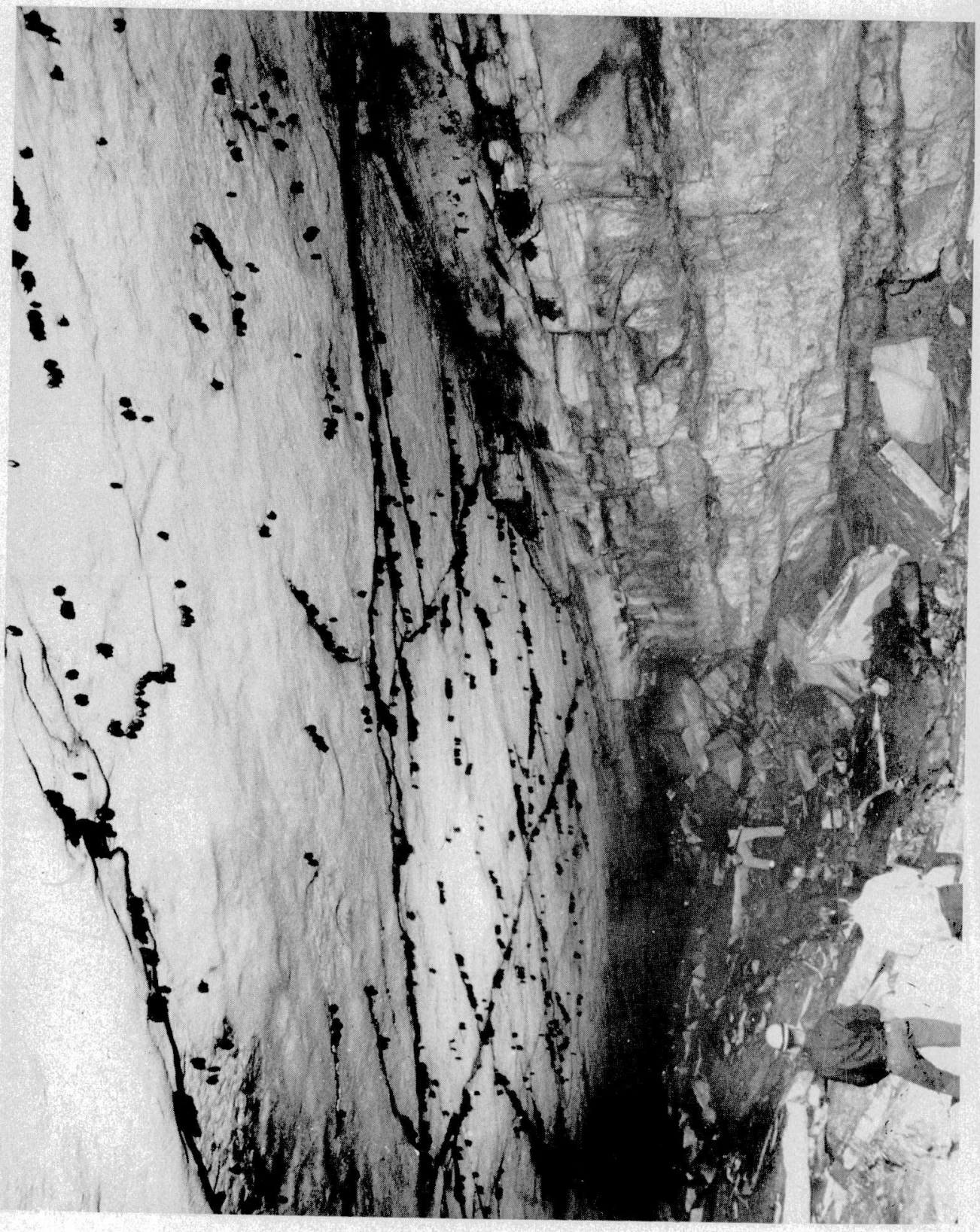




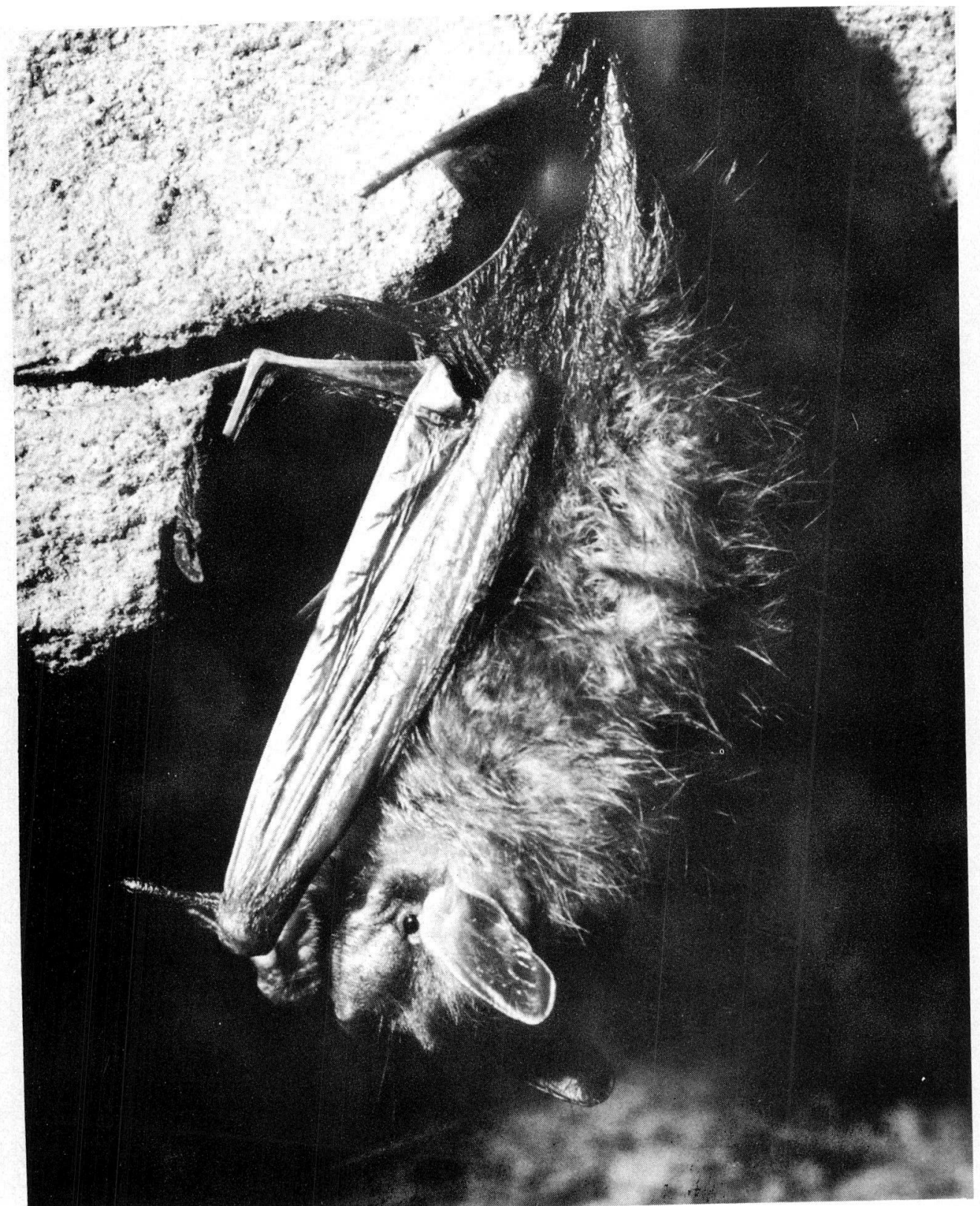




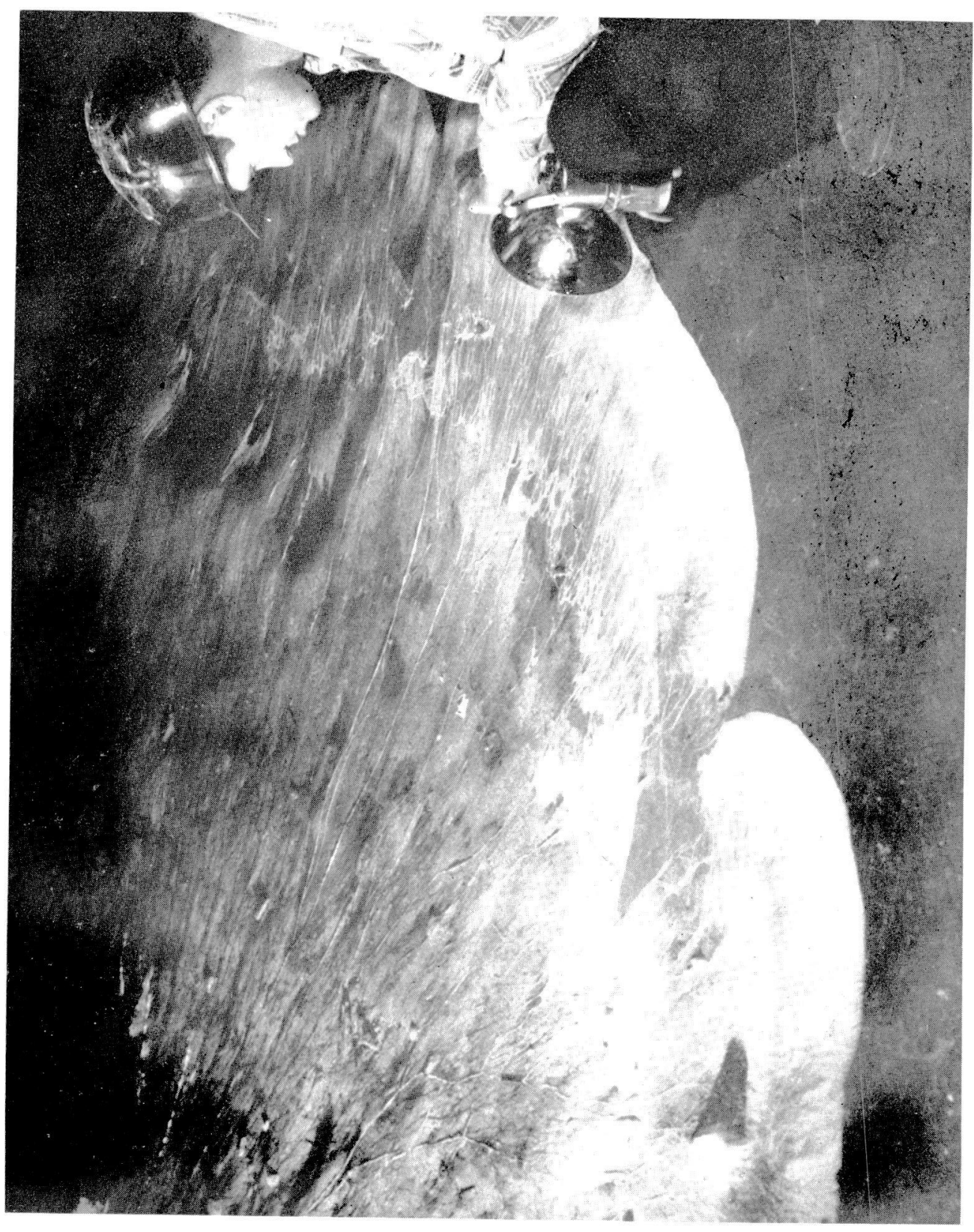

